\title{
Akzeptanz des Ausbaus der erneuerbaren Energien in Deutschland unter Berücksichtigung von Raumdaten und Gerechtigkeitsaspekten
}

\author{
Dissertation \\ zur Erlangung des Doktorgrades \\ der Fakultät für Agrarwissenschaften \\ der Georg-August-Universität Göttingen

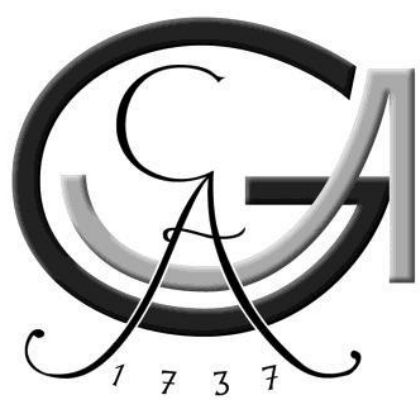

vorgelegt von

Geesche Marie Dobers, geb. Merkle

geboren in Esslingen (Neckar)

Göttingen, März 2019 
D7

1. Referent: Prof. Dr. Ulf Liebe

2. Korreferent: Prof. Dr. Oliver Mußhoff

3. Korreferent: Prof. Dr. Achim Spiller

Tag der mündlichen Prüfung: 2. Mai 2019 


\section{Danksagung}

Nun endlich steht die Abgabe meiner Dissertation kurz bevor und ich möchte mich an dieser Stelle bei all denjenigen bedanken, die mich auf dem Weg bis zur Abgabe begleitet und unterstuitzt haben.

Zunächst gilt mein Dank dem Betreuer meiner Dissertation, Prof. Dr. Ulf Liebe. Ihm danke ich für die Überlassung des Themas, für seine Geduld und für viele wertvolle Hinweise während der Promotionsphase. Prof. Dr. Oliver Mußhoff danke ich für die Übernahme des Zweitgutachtens sowie Prof. Dr. Achim Spiller für die Übernahme des Drittgutachtens.

Für viel Freude während der Arbeit haben Malte Oehlmann und Jürgen Meyerhoff, Projektpartner von der TU Berlin, gesorgt. Die sehr unkomplizierte und offene Zusammenarbeit und den vielfältigen fachlichen Austausch mit ihnen habe ich sehr geschätzt, ebenso wie ihren Sinn dafür, die Arbeit auch immer mit etwas Angenehmem zu verbinden. So ist die Arbeit im Projekt EnergyEffair für mich auch immer mit schönen Erinnerungen an FG-Reisen und ähnliche Unternehmungen verbunden, vielen Dank dafür!

Eine weitere wichtige Person während der Promotionsphase war meine Kollegin Veronika Andorfer, die mir bis heute als Kollegin zur Seite steht, obwohl der Lehrstuhl an dem wir zusammen gearbeitet haben, schon lange nicht mehr besteht. Ihr möchte ich danken, dass ich sie immer um fachlichen Rat bitten konnte. Sie gab mir viele wertvolle Hinweise und hat mir mit Blick auf die Dissertation viel Mut gemacht. Das schöne ist aber vor allem, dass aus der Kollegin eine gute Freundin geworden ist, darüber freue ich mich sehr!

Prof. Dr. Ulrich Hamm und seiner Arbeitsgruppe möchte ich herzlich danken, dass ich bei ihnen so gut aufgenommen wurde und in Witzenhausen eine wunderbare „Ersatz-Arbeitsgruppe“ gefunden habe. Die Einbettung und der Austausch dort waren für mich sehr aufbauend und haben mir und meiner Arbeit einen hilfreichen Rahmen gegeben.

Außerdem standen mir Gesa Busch und Steffi Ammer als Göttinger Freundinnen zur Seite. Eva Spaeth und Britta Niggebaum haben mich als Freundinnen aus der Ferne unterstützt. Allen vieren danke ich, dass sie immer ein offenes Ohr haben!

Mein ganz besonderer Dank geht an meine Familie. Lola und Aenne haben mich gelehrt, endlich diese Arbeit abzuschließen, denn es gibt wirklich Wichtigeres im Leben. Stefan hat mich unermüdlich unterstützt und das mit viel Humor! Ich danke euch dreien, dass ich bei euch so gut aufgehoben bin! 
Inhaltsverzeichnis

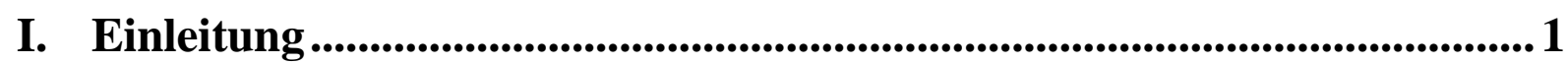

II. Decomposing public support for energy policy: What drives acceptance of and intentions to protest against renewable energy expansion in Germany?

III. Spatial dimension of social acceptance of renewable energies and related infrastructure - a quantitative literature review

IV. Acceptance of biogas plants taking into account space and place 45

V. Factorial survey experiments and direct measurements of fairness perceptions in energy justice research .................................................... 76

VI. Zusammenschau und Diskussion der Ergebnisse ...................................93

VII. Zusammenfassung .............................................................................................. 103

Erklärung über den geleisteten Eigenanteil ........................................................105

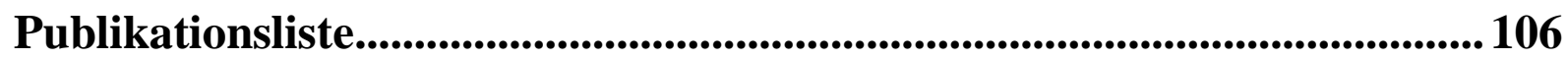

Eidesstattliche Erklärungen .......................................................................107 


\section{Einleitung}

Der als Klimawandel bezeichnete weltweite Temperaturanstieg gilt mittlerweile als wissenschaftlich erwiesen ebenso wie seine Verursachung durch den Menschen (Cook et al. 2016; IPCC 2015). Um seine prognostizierten negativen Auswirkungen auf die Umwelt möglichst einzuschränken, haben sich 1997 die Industrieländer in dem 2004 rechtskräftig gewordenen Kyoto-Protokoll und 2015 die internationale Gemeinschaft im Pariser Klimaabkommen zu einer Begrenzung der klimarelevanten Emissionen von $\mathrm{CO}_{2}$ und anderen Treibhausgasen verpflichtet. Ziel beider Vereinbarungen war die Begrenzung des Anstiegs der mittleren Jahrestemperatur auf $2^{\circ} \mathrm{C}$ (Kyoto) bzw. möglichst $1,5^{\circ} \mathrm{C}$ (Paris). In diesem Zusammenhang hat sich die Bundesrepublik Deutschland zum Ziel gesetzt, die Emission relevanter Treibhausgase bis 2030 um 55\% zu verringern (BMU 2018). Vor dem Hintergrund des Reaktorunfalls in Fukushima 2011 wurde außerdem der deutsche Atomausstieg bis 2022 beschlossen. Diese beiden Beschlüsse bilden den Ausgangspunkt für die sogenannte Energiewende, also den Wandel weg von einer auf fossilen Energieträgern und Kernenergie basierenden Energieversorgung hin zu erneuerbaren Energien und höherer Energieeffizienz (EWI 2013).

Ein wesentliches Handlungsfeld der Energiewende ist neben den Bereichen Mobilität und Wärmeversorgung die Stromerzeugung. Basierend auf dem Erneuerbare Energien Gesetz (EEG) aus dem Jahr 2000 schreitet in diesem Bereich die Energiewende am stärksten voran (Hook 2018): 2017 kam 36\% des Bruttostromverbrauchs ${ }^{1}$ aus erneuerbaren Energien verglichen mit 6\% im Jahr 2000. Die dabei am stärksten genutzten erneuerbaren Energieträger sind Wind-, Solar- und Bioenergie, jeweils mit einem Anteil von 49\%, 18\% und 14\% an der Stromerzeugung aus erneuerbaren Energien in 2017. Bis 2030 soll zur Erreichung der Klimaziele 50\% des Bruttorstromverbrauchaus aus erneuerbaren Energien erzeugt werden, so dass eine weitere deutliche Zunahme von Anlagen in Kombination mit einer Effizienzsteigerung der vorhandenen Anlagen zu erwarten ist (BMWi 2018).

\section{Forschungsgegenstand der Dissertation}

Im Gegensatz zum bisherigen System der zentralen Stromversorgung erfolgt der Bau von Stromerzeugungsanlagen aus erneuerbaren Energien dezentral im ländlichen Raum. Dies führt

\footnotetext{
1 „Der Bruttostromverbrauch entspricht der Summe der gesamten inländischen Stromgewinnung [...], zuzüglich der Stromflüsse aus dem Ausland und abzüglich der Stromflüsse ins Ausland.“ (BMWi 2015, S. 69)
} 
einerseits $\mathrm{zu}$ deutlichen Landschaftsveränderungen, denn charakteristisch für erneuerbare Energien sind ihr hoher Flächenbedarf - beispielsweise von Solarfeldern oder des Substratanbaus für Biogasanlagen - und ihre landschaftsbildprägenden Eigenschaften insbesondere von Windrädern - und damit eine hohe Raumrelevanz (Megerle 2013; Kost 2013). Formulierungen wie ,Technisierung der Kulturlandschaft ${ }^{\star}$, ,Verunstaltung des Landschaftsbildes‘, ,Verspargelung' oder, Vermaisung‘ stehen für die kritische bis ablehnende Haltung, die dem Ausbau der erneuerbaren Energien entgegensteht (Bosch und Peyke 2011). Durch den dezentralen Charakter der Stromversorgung aus erneuerbaren Energien sind viele Bürger von ihren negativen Umwelteffekten betroffen. Andererseits bietet die Energiewende im Strombereich aber auch die Möglichkeit zu kommunalen Energieprojekten wie beispielsweise Bioenergiedörfer (Wüste und Schmuck 2013), zur finanziellen Teilhabe (Jenkins et al. 2016) sowie zur Mitgestaltung.

Umfrageinstitute berichten konstant über die letzten Jahre hinweg, dass ein großer Teil der deutschen Bevölkerung den Ausbau der erneuerbaren Energien befürwortet (beispielsweise 93\% Befürwortung in 2018 und 2012 (AEE 2018, 2012)). Gleichzeitig ist mit der steigenden Anzahl von Projekten zum Anlagenbau auch die Zahl der Bürgerproteste deutlich gestiegen (Marg et al. 2013). Dabei ist die Skepsis gegenüber lokalen Ausbauprojekten kein neues Phänomen, sondern existierte bereits vor der Energiewende. Die Zunahme der Standortkonflikte ergibt sich zwangsläufig aus dem dezentralen Charakter und dem fortschreitenden Ausbau der erneuerbaren Energien (Marg et al. 2013).

Voraussetzung für die erfolgreiche Umsetzung der angestrebten Energiewende ist der Erfolg der einzelnen Projekte zum Ausbau der erneuerbaren Energien auf lokaler Ebene. Damit besteht gesamtgesellschaftlich ein hohes Interesse daran, die Gründe für Akzeptanz und Ablehnung des Ausbaus der erneuerbaren Energien auf lokaler Ebene zu verstehen. Dies spiegelt sich in einer hohen Zahl wissenschaftlicher Veröffentlichungen wider. Die vorliegende Dissertation trägt dreierlei zu diesem Forschungsfeld bei:

- In einer breiteren Herangehensweise wird zunächst die Erklärungskraft konkurrierender theoretischer Ansätze für Akzeptanz und Protest untersucht.

- Daraufhin wird der Raumwirksamkeit der Anlagen zur Stromerzeugung aus erneuerbaren Energien Rechnung getragen, indem die Erklärungskraft räumlicher Informationen für die Akzeptanz untersucht wird.

- Zuletzt fokussiert die Dissertation auf Aspekte der Verteilungs- und Verfahrensgerechtigkeit, die sich aus der Dezentralität des Ausbaus der erneuerbaren 
Energien und der damit verbundenen gesellschaftlichen Teilhabe an negativen und positiven Umwelteffekten sowie der Möglichkeit zur Mitgestaltung ergeben.

Auch der methodische Beitrag der Arbeit ist dreierlei, indem sie Beispiele bietet für

- die Verwendung von Dekompositionsmodellen zur Differenzierung des Effekts von Einstellungen,

- die Verknüpfung von räumlichen Daten mit Umfragedaten zur Berücksichtigung des räumlichen Kontextes von Befragten

- den Einsatz von Faktoriellen Survey Experimenten zur Messung von wahrgenommener Gerechtigkeit.

Grundlage für alle statistischen Analysen im Rahmen dieser Dissertation sind Daten aus einer deutschlandweiten online-Befragung mit 3400 Teilnehmern, die 2013 im Rahmen des Projekts EnergyEFFAIR (Förderkennzeichen 01LA1110C) durchgeführt wurde.

\section{Begriffsbestimmung Akzeptanz}

Basierend auf Lucke (1995) und Schweizer-Ries (2008) ist Akzeptanz das positive Ergebnis eines sozialen Bewertungsprozesses eines Akzeptanzobjekts (z.B. der Bau eines Windrades) durch ein Akzeptanzsubjekt (z.B. ein Anwohner). Dieser Bewertungsprozess ist durch den Akzeptanzkontext (Ort, beteiligte Akteure, Bedingungen) geprägt. Akzeptanz umfasst dabei zwei Dimensionen: einerseits die Einstellungsdimension, d.h. die Bewertung des Objekts auf kognitiver, affektiver und konativer Ebene und andererseits die Handlungsdimension, die sich in passivem oder aktivem Verhalten zeigt. Daraus ergeben sich vier Formen der Akzeptanz: Befürwortung als passives und Unterstützung bzw. Engagement als aktives Verhalten der positiven Bewertung sowie Ablehnung und Widerstand als passive und aktive Verhaltensausprägungen der negativen Bewertung (Hildebrand et al. 2018; Gölz und Wedderhoff 2018). In einer breiten Definition reicht Akzeptanz von passiver Befürwortung bis $\mathrm{zu}$ aktiver Unterstützung, in einer engen Sichtweise umfasst sie nur aktive Unterstützung (Schweizer-Ries 2008).

Mit Blick auf die Akzeptanzforschung im Bereich der erneuerbaren Energien bieten Wüstenhagen et al. (2007) einen konzeptionellen Rahmen und unterscheiden darin drei unterschiedliche Bezugsebenen der Akzeptanz: Die sozio-politische Akzeptanz (socio-political acceptance) bezieht sich auf die generelle Akzeptanz des Ausbaus der erneuerbaren Energien, von den damit verbundenen politischen Maßnahmen bis hin zu den verwendeten Technologien. Die lokale Akzeptanz (community acceptance) umfasst die Akzeptanz lokaler Ausbauprojekte, 
also beispielsweise der Bau eines konkreten Windparks. Die Marktakzeptanz (market acceptance) hat die Annahme der neuen Technologien am Markt zum Inhalt, beispielsweise die Nachfrage nach Ökostrom durch die Verbraucher oder die Nachfrage nach neuen Technologien mit Bezug zu erneuerbaren Energien durch Unternehmen.

Entsprechend des Ausbaus der erneuerbaren Energien weltweit hat die Zahl der Studien zum Thema Akzeptanz erneuerbarer Energien seit circa 2005 stark zugenommen (Gaede und Rowlands 2018). Ein großer Teil der Studien beschäftigte sich dabei mit den Ursachen der zunehmend schwindenden Akzeptanz auf lokaler Ebene im Gegensatz zu einer hohen soziopolitischen Akzeptanz der erneuerbaren Energien. Hier handelt es sich um unterschiedliche Akzeptanzobjekte, bei deren Bewertung unterschiedliche Einflussfaktoren eine Rolle spielen bzw. deren Gewichtung bei der jeweiligen Bewertung voneinander abweicht (Wolsink 2012, 2018). Trotzdem war der vermeintliche Gegensatz - auch als social gap bezeichnet (Bell et al. 2013) - zwischen sozio-politischer Akzeptanz und lokaler Akzeptanz von erneuerbaren Energien Ausgangspunkt für eine Vielzahl von Untersuchungen. Aufhänger war dabei häufig die landläufige Erklärung von lokalem Widerstand mit dem sogenannten Not-In-My-BackyardPrinzip (NIMBY). NIMBY beschreibt dabei ein eigennütziges Trittbrettfahrerverhalten, bei dem beispielsweise der Bau eines Windrads aufgrund damit verbundener negativer Umwelteffekte ausschließlich in der eigenen Umgebung abgelehnt, jedoch außerhalb der eigenen Umgebung befürwortet wird (Bell et al. 2013). NIMBY beschreibt somit rationales Verhalten in einem sozialen Dilemma (Kollock 1998).

Mittlerweile besteht weitestgehend wissenschaftlicher Konsens darüber, dass NIMBY als alleinige Erklärung für die lokale Ablehnung erneuerbarer Energien unzureichend ist, da das Konzept viel zu stark vereinfacht, Gegner abschätzig bewertet (Wolsink 2007b; Devine-Wright 2005, 2009) und empirisch nur für einen kleinen Teil der Bevölkerung nachgewiesen werden kann (Wolsink 2007b). Stattdessen haben sich aus einer Vielzahl wissenschaftlicher Disziplinen, die sich dem Thema angenommen haben, zahlreiche Erklärungsansätze herausgebildet, die die Ursachen für Widerstand gegen konkrete Ausbauprojekte von unterschiedlichen Seiten beleuchten (s. Devine-Wright 2005; Huijts et al. 2012; Perlaviciute und Steg 2014). Tabelle 1 gibt dazu einen Überblick. 
Tabelle 1: Bisher untersuchte Einflussfaktoren auf lokale Akzeptanz von erneuerbaren Energien.*

\begin{tabular}{|c|c|c|}
\hline Erklärungsansatz & Kern des Ansatzes & Autoren (Auswahl) \\
\hline $\begin{array}{l}\text { Fairness / } \\
\text { Gerechtigkeit }\end{array}$ & $\begin{array}{l}\text { Wahrgenommene Verfahrens- und } \\
\text { Verteilungsgerechtigkeit als wesentliche } \\
\text { Indikatoren dafür, inwiefern die Belange der } \\
\text { betroffenen Anwohner berücksichtigt werden. }\end{array}$ & $\begin{array}{l}\text { Gross (2007); Wolsink } \\
\text { (2007a, 2007b); Liebe et } \\
\text { al. (2017) }\end{array}$ \\
\hline Vertrauen & $\begin{array}{l}\text { Vertrauen in Entscheidungsträger kann } \\
\text { unzureichendes Wissen oder fehlende Erfahrung } \\
\text { ausgleichen; steht in Verbindung zur } \\
\text { Verfahrensgerechtigkeit. }\end{array}$ & $\begin{array}{l}\text { Aitken (2010); Huijts et } \\
\text { al. (2012); Soland et al. } \\
\text { (2013) }\end{array}$ \\
\hline Place Attachment & $\begin{array}{l}\text { Die emotionale Verbundenheit zur räumlichen } \\
\text { Umgebung / Landschaft führt zur Ablehnung von } \\
\text { Veränderung. }\end{array}$ & $\begin{array}{l}\text { Vorkinn und Riese } \\
\text { (2001); Devine-Wright } \\
\text { (2009) }\end{array}$ \\
\hline $\begin{array}{l}\text { Proximity / } \\
\text { Räumliche Nähe }\end{array}$ & $\begin{array}{l}\text { Nähe zu Anlagen ist verbunden mit höherer } \\
\text { Sensibilisierung oder Gewöhnung - unklarer } \\
\text { Wirkungszusammenhang bzw. u-förmig im } \\
\text { Zeitverlauf vom Beginn der Planung bis zur } \\
\text { Fertigstellung der Anlage }\end{array}$ & $\begin{array}{l}\text { Warren et al. (2005); } \\
\text { van der Horst (2007); } \\
\text { Ladenburg und Möller } \\
\text { (2011); Wolsink } \\
(2007 \mathrm{~b})\end{array}$ \\
\hline Einstellungen & $\begin{array}{l}\text { Wie werden Anlagen bewertet? } \\
\text { Welche Rolle spielt die Bewertung des generellen } \\
\text { Kontexts, z.B. Sorge über den Klimawandel? }\end{array}$ & $\begin{array}{l}\text { Ansolabehere und } \\
\text { Konisky (2009); } \\
\text { Swofford und Slattery } \\
(2010)\end{array}$ \\
\hline $\begin{array}{l}\text { Theorie geplanten } \\
\text { Handelns }\end{array}$ & $\begin{array}{l}\text { Zusammenspiel von Einstellungen, die aus der } \\
\text { Abwägung von Kosten, Risiken und Vorteilen } \\
\text { resultieren, wahrgenommener sozialer Norm und } \\
\text { wahrgenommener Wirkungsmächtigkeit als } \\
\text { Einflussfaktoren auf das (beabsichtigte)Verhalten }\end{array}$ & $\begin{array}{l}\text { Johansson und Laike } \\
\text { (2007); Read et al. } \\
\text { (2013) }\end{array}$ \\
\hline $\begin{array}{l}\text { Wahrgenommene } \\
\text { Kosten, Risiken, } \\
\text { Vorteile }\end{array}$ & $\begin{array}{l}\text { Welche Kosten, Risiken und Vorteile werden im } \\
\text { Zusammenhang mit der Planung und dem Bau von } \\
\text { Anlagen wahrgenommen? }\end{array}$ & $\begin{array}{l}\text { Jones und Eiser (2009); } \\
\text { Baxter et al. (2013) }\end{array}$ \\
\hline Soziale Normen & $\begin{array}{l}\text { wahrgenommene Erwartung sozialrelevanter } \\
\text { Bezugspersonen }\end{array}$ & Read et al. (2013) \\
\hline $\begin{array}{l}\text { Bedingte } \\
\text { Kooperation }\end{array}$ & $\begin{array}{l}\text { Individueller Beitrag zu einem öffentlichen Gut } \\
\text { (z.B. Reduktion von } \mathrm{CO}_{2} \text {-Emissionen) ist vom } \\
\text { Beitrag anderer abhängig. }\end{array}$ & $\begin{array}{l}\text { Ek und Söderholm } \\
\text { (2007) }\end{array}$ \\
\hline Information & $\begin{array}{l}\text { Zusammenhang zwischen Information und } \\
\text { Einstellungen }\end{array}$ & $\begin{array}{l}\text { Soland et al. (2013); } \\
\text { Bidwell (2016) }\end{array}$ \\
\hline
\end{tabular}

* Die grau hinterlegten Erklärungsansätze werden auch in der vorliegenden Arbeit berücksichtigt.

Es zeigt sich, dass die Forschung zur lokalen Akzeptanz von erneuerbaren Energien bereits stark aufgefächert ist und von unterschiedlichen Forschungsdisziplinen bedient wird. In den vier Beiträgen der vorliegenden Dissertation können nicht alle der oben genannten Einflussfaktoren berücksichtigt werden, stattdessen wurde eine Auswahl getroffen. In der folgenden Vorstellung der vier Forschungsbeiträge dieser Dissertation bietet der inhaltliche Fokus einen ersten Einblick in die gewählten Einflussfaktoren, nähere Erläuterungen dazu 
folgen in den einzelnen Kapiteln. Zudem wird für jeden Beitrag der methodische Fokus dargestellt.

\section{Aufbau der Dissertation}

\subsection{Beitrag 1: Untersuchung anhand ausgewählter Einflussfaktoren und Verwendung von Dekompositionsmodellen}

\section{Inhaltlicher Fokus}

In der bisherigen Forschung wurden unterschiedliche Einflussfaktoren herausgearbeitet, die einen Erklärungsbeitrag zur lokalen Akzeptanz von erneuerbaren Energien leisten können. Sie basieren auf unterschiedlichen Theorien aus der Soziologie, Sozialpsychologie und Ökonomie. Beispielsweise sind Einstellungen und soziale Normen die zentralen Einflussfaktoren auf das Verhalten in Ajzens (1991) Theorie geplanten Handelns, persönliche Normen dienen zur Erklärung von altruistischem Verhalten im Normaktivierungsmodell von Schwartz (1977). Diese Theorien sind zentrale Konzepte der Sozialpsychologie, die in der Umweltsoziologie breite Anwendung finden (Liebe 2007).

Für sich genommen kann jedes Konzept einen Erklärungsbeitrag zur lokalen Akzeptanz von erneuerbaren Energien liefern. Darüber hinaus interessant ist ihre Wirkung in der Zusammenschau als konkurrierende erklärende Konzepte. In der Zusammenschau zeigt sich, welche Konzepte dominieren und welche ihre Erklärungskraft verlieren. Anwendung fand diese Idee beispielsweise in den Studien von Andorfer und Liebe (2013) und Liebe et al. (2011), in denen Einflussfaktoren auf den Kauf von Fairtrade-Produkten einerseits und Zahlungsbereitschaften für Naturschutzmaßnahmen in Wäldern im Wettbewerb untersucht werden, also in zwei sehr unterschiedlichen Anwendungsbereichen der Umweltsoziologie. Diese Artikel dienen bei der Anwendung im Kontext der lokalen Akzeptanz von erneuerbaren Energien als Vorlage. Als konkurrierende theoretische Ansätze wurden folgende Einflussfaktoren gewählt: Einstellungen, Normen und bedingte Kooperation als zentrale Konzepte der umweltsoziologischen Forschung und NIMBY und place attachment als Konzepte aus der aktuellen Forschung im Bereich der lokalen Akzeptanz von erneuerbaren Energien, die sich beide zentral auf die Wohnumgebung der Betroffenen beziehen.

\section{Methodischer Fokus}

Der Ausbau der erneuerbaren Energien erfordert den Einsatz unterschiedlicher Technologien um die zum Teil schwankende Verfügbarkeit der verwendeten Ressourcen ausgleichen zu 
können. So können Wind- und Solarenergie zwar zeitweise sehr hohe Erträge liefern, Biogas hingegen liefert geringere aber verlässliche bzw. planbare Erträge, mit denen Schwankungen ausgeglichen werden können. Entsprechend sollte auch die Akzeptanz aller drei erneuerbaren Energieträger untersucht werden und damit die Tatsache Berücksichtigung finden, dass die Bewertung des einen Energieträgers nicht losgelöst vom anderen erfolgt. Einerseits kann so dem ergänzenden Charakter und der Abwägung von Vor- und Nachteilen in der Bewertung Rechnung getragen werden, andererseits kann ermittelt werden, inwiefern eine Technologie der erneuerbaren Energien der anderen vorgezogen wird. Möglich ist diese Analyse mithilfe eines statistischen Dekompositionsmodells, das in der Regel im Kontext der Forschung zur Lohndiskriminierung angewendet wird (Blinder 1973; Oaxaca 1973). Unterschiede in der Bewertung zweier Gruppen werden dabei in einen erklärten und einen unerklärten Teil zerlegt. Der erklärte Teil (endowment effect) beruht auf Unterschieden in den Mittelwerten der unabhängigen Variablen für beide Gruppen, während der unerklärte Teil (discrimination effect und characteristic effect für soziodemographische Variablen) aus Unterschieden in den Koeffizienten resultiert (Jann 2008). Ansolabehere und Konisky (2009) haben diese Methode zur Untersuchung der lokalen Akzeptanz unterschiedlicher Kraftwerkstypen (Wind-, Kohle-, Gas- und Atomkraftwerk) in den USA eingesetzt und gezeigt, dass mit Blick auf den endowment effect insbesondere die wahrgenommenen Umweltauswirkungen der einzelnen Kraftwerke für ihre Bewertung relevant ist. Die Autoren konnten weder einen characteristic effect noch einen wesentlichen discrimination effect feststellen, jedoch berichten sie, dass Windenergie grundsätzlich den anderen Energieträgern vorgezogen wird. Die Ergebnisse der Dekompostionsmethode können somit ein differenzierteres Bild zeichnen als herkömmliche Einstellungsuntersuchungen. Die Anwendung im deutschen Kontext erscheint sinnvoll, da sich der deutsche Energiemix deutlich vom amerikanischen unterscheidet.

Der Beitrag "Decomposing public support for energy policy: What drives acceptance of and intentions to protest against renewable energy expansion in Germany? " in Kapitel II der vorliegenden Dissertation kombiniert die Zerlegung des Einflusses konkurrierender Theorien mit der Zerlegung des Effektes von Einstellungen auf die Akzeptanz und bietet somit eine zweifache Dekomposition, einerseits in theoretischer und andererseits in methodischer Hinsicht. 


\subsection{Beiträge 2 und 3: Proximity - Integration und Erklärungsbeitrag räumlicher Informationen}

\section{Inhaltlicher Fokus}

Im Kontext der Akzeptanz lokaler Anlagen zur Stromerzeugung aus erneuerbaren Energien war die Bedeutung der Nähe zu (potentiellen) Anlagen von Anfang an im Fokus der Betrachtung. So ist die räumliche Nähe zu Anlagen bei der Anwendung des NIMBY-Prinzips eine zentrale Voraussetzung. Doch auch nachdem weitestgehend Konsens darüber besteht, dass NIMBY ein unzureichendes Konzept ist, um allein damit die Ablehnung von erneuerbaren Energien auf lokaler Ebene zu erklären, besteht weiterhin Interesse an dem Wirkungszusammenhang zwischen räumlicher Nähe und Akzeptanz. Grundlegend dafür ist der Gedanke, dass der Wohnort in der Nähe eines bestimmten Ortes oder einer bestimmten Umwelteigenschaft das Wissen und die Wahrnehmung des Einzelnen beeinflusst und somit zu einer stärkeren Sensibilisierung bezüglich dieses Ortes oder bezüglich dieser bestimmten Eigenschaft beiträgt. Tritt eine Veränderung des gegebenen Zustandes ein, so erfolgt eine genaue Evaluierung ihrer Folgen, beispielsweise werden die durch die Veränderung verursachten Kosten, ihr Nutzen oder das mit ihr verbundene Risiko abgewogen (Venables et al. 2012; Brody et al. 2004).

Während Dear (1992) vor diesem Hintergrund generell annimmt, dass sich die räumlich Nähe $\mathrm{zu}$ einer unerwünschten Einrichtung negativ auf deren Akzeptanz auswirkt (proximityHypothese) berichten andere Autoren (z.B. Wolsink 2007b; Devine-Wright 2005) mit Blick auf die Entwicklung eines Windparks einen u-förmigen Verlauf der Akzeptanz: wird ein Projekt konkret, so steigt die Ablehnung, da insbesondere die negativen Konsequenzen in Betracht gezogen werden. Nach dem Bau einer Anlage steigt die Akzeptanz jedoch wieder. Ursache kann ein Gewöhnungseffekt sein (Devine-Wright 2005), oder die verstärkte Wahrnehmung von ökonomischen und sozialen Vorteilen (Venables et al. 2012). Eine weitere Erklärungsmöglichkeit ist die Vermeidung kognitiver Dissonanz (Festinger 1957), also die Anpassung der eigenen Einstellung an die nicht veränderbaren räumlichen Gegebenheiten, in diesem Fall den existierenden Windpark (Venables et al. 2012).

\section{Methodischer Fokus}

Die Berücksichtigung des Raumes reicht in den Sozialwissenschaften bis zur Humanökologie der 1920er Jahre (Brody et al. 2004; Porter und Howell 2012) zurück und stößt, nachdem sie über längere Zeit kaum Beachtung gefunden hat, in den letzten Jahren insbesondere in der Umweltsoziologie und -psychologie wieder auf vermehrtes Interesse (Brody et al. 2004). Kern 
dieser Forschungsausrichtung ist die Frage nach dem Wo: "[s]patial thinking is about where things are and where they happen, and it is especially about where they are in relation to others." (Logan 2012, S. 508). Aus diesem Fokus resultiert das zentrale Maß der Berücksichtigung des Raumes, die Distanz. Sie dient zum einen als „Indikator des Zugangs zu anderen Personen oder zu Ressourcen sowie als Indikator der Belastung mit negativen Umwelteffekten“ (Logan 2012, S. 511, eigene Übersetzung).

Zahlreiche Autoren betonen, dass räumliche Informationen einen wertvollen Erklärungsbeitrag in der sozialwissenschaftlichen Forschung leisten können (Diekmann und Meyer 2010; Downey 2006; Goodchild et al. 2000; Logan 2012; Porter und Howell 2012) und verweisen in diesem Zusammenhang auf die Entwicklung Geographischer Informationssysteme (GIS). Ein GIS bietet die Möglichkeit, räumliche Daten zu verarbeiten und zu präsentieren, sowie räumliche Beziehungen zwischen Objekten (wie beispielsweise die Distanz) zu erfassen (Meyer und Bruderer Enzler 2013). Aufgrund der zunehmenden Verfügbarkeit räumlicher Informationen ist es über das GIS möglich, im Rahmen der sozialwissenschaftlichen Datenanalyse objektive Informationen über die individuelle Lebens(um)welt von Befragten zu erfassen und zu berücksichtigen. Diese Daten sind im Gegensatz zu selbstberichteten räumlichen Informationen, die im Rahmen von Befragungen erhobenen werden, oder im Gegensatz zu stark aggregierten und an administrative Grenzen gebundene räumlichen Informationen, die sich über die Postleitzahl oder ähnliche Angaben mit Befragungsdaten verknüpfen lassen (Meyer und Bruderer Enzler 2013) deutlich genauer.

In der Umweltsoziologie werden räumliche Daten beispielsweise in Studien zur Umweltgerechtigkeit berücksichtigt, die untersuchen, ob sozial schlechter gestellte Bevölkerungsgruppen stärker von negativen Umwelteffekten betroffen sind (z.B. Diekmann und Meyer 2010). Andere Autoren berücksichtigen räumliche Informationen in Studien zum Umweltbewusstsein (Brody et al. 2004), zur Wahrnehmung von Umweltrisiken (Mahafza et al. 2017) und zu Standortentscheidungen von Energieinfrastruktur im Allgemeinen (Clarke et al. 2016; Gravelle und Lachapelle 2015; Venables et al. 2012).

Die hohe Raumrelevanz von erneuerbaren Energien spricht dafür, auch in Untersuchungen zur lokalen Akzeptanz erneuerbarer Energien räumliche Informationen wie proximity zu integrieren. Vor diesem Hintergrund beinhaltet der Beitrag „,Spatial dimension of social acceptance of renewable energies and related infrastructure - a quantitative literature review “ in Kapitel III einen Literaturüberblick über den Einfluss von räumlichen Merkmalen wie beispielsweise proximity auf die lokale Akzeptanz von erneuerbaren Energien. Der Beitrag 
„Acceptance of biogas plants taking into account space and place“ in Kapitel IV widmet sich der Akzeptanz von Biogasanlagen unter besonderer Berücksichtigung räumlicher Informationen zum Umfang des Maisanbaus als Rohstoff für die Biogaserzeugung und Entfernung und Anzahl von Biogasanlagen in der Umgebung der Befragten. Ziel beider Beiträge ist es einerseits, aus inhaltlicher Sicht zu untersuchen, in wie weit räumliche Aspekte die lokale Akzeptanz erneuerbarer Energien beeinflussen, sowie andererseits aus methodischer Sicht, ein Beispiel zu geben, wie Raumdaten in die Analyse von Umfragedaten integriert werden können.

\subsection{Beitrag 4: Untersuchung von Gerechtigkeitsaspekten unter Verwendung eines Faktoriellen Survey Experiments}

\section{Inhaltlicher Fokus}

Umweltgerechtigkeit (environmental justice) im Allgemeinen beschäftigt sich mit „Ungleichheiten von Umweltrisiken, -ressourcen und -beeinträchtigungen“ (Elvers 2011, S. 477) und zieht dabei die drei Gerechtigkeitsdimensionen Verteilung von Lasten und Nutzen (Verteilungsgerechtigkeit - distributional justice), Beteiligung und Mitgestaltung in Entscheidungsprozessen (Verfahrensgerechtigkeit - procedural justice) und Anerkennung unterschiedlicher Positionen und Bevölkerungsgruppen (anerkennungsbasierte Gerechtigkeit recognition-based justice) in Betracht (Schlosberg 2007). In Anlehnung an die Umweltgerechtigkeit hat sich für den Themenkomplex Energie das Konzept Energy Justice entwickelt (Jenkins et al. 2016). Sovacool et al. (2016, S. 4) definieren Energy Justice als „a global energy system that fairly distributes both the benefits and burdens of energy services, and one that contributes to more representative and inclusive energy decision-making”. Energy Justice dient sowohl als theoretisches als auch als politisches und handlungspraktisches Konzept (McCauley et al. 2019). Die Forschung im Bereich Energy Justice beschäftigt sich mit der Anwendung der genannten Gerechtigkeitsdimensionen auf die Bereitstellung und den Konsum von Energie und untersucht deren soziale Auswirkungen (Jenkins et al. 2016; Bickerstaff 2017).

Im Kontext des Ausbaus der erneuerbaren Energien betonen einige Autoren die Bedeutung insbesondere von wahrgenommener Verfahrens- und Verteilungsgerechtigkeit für die lokale Akzeptanz (Wolsink 2007a, 2007b; Gross 2007; Baxter 2017; Perlaviciute und Steg 2014). Verfahrensgerechtigkeit bezieht sich in diesem Kontext auf die Gestaltung des Planungs- und Entscheidungsprozesses eines Anlagenbaus. Ein gerechtes Verfahren ist dabei durch die 
gleichberechtigte Möglichkeit zur Beteiligung und freien Meinungsäußerung, gegenseitigen Respekt, Transparenz und die Bereitstellung von Information, Neutralität der Entscheidungsträger und Revidierbarkeit von Entscheidungen gekennzeichnet (Gross 2007; Leventhal 1980). Dabei stellt die Gleichberechtigung aller Beteiligten eine Schnittstelle zum Prinzip der anerkennungsbasierten Gerechtigkeit dar (Jenkins et al. 2016; Bickerstaff 2017), das explizit jedoch kaum Berücksichtigung findet. Die Bedeutung der Verfahrensgerechtigkeit liegt in der Möglichkeit zur Einflussnahme. Im Kontext des Ausbaus der erneuerbaren Energien bedeutet diese, dass Anwohner auf die Gestaltung und Veränderung ihres Wohnumfeldes Einfluss nehmen können (Lienhoop 2018). Projekte, die durch fehlende Verfahrensgerechtigkeit charakterisiert sind, werden eher abgelehnt (Wolsink 2007b). Im Gegensatz dazu werden Projekte, in denen Verfahrensgerechtigkeit gewährleistet ist, eher akzeptiert, auch wenn ihr Ergebnis unvorteilhaft für die Beteiligten ist (Aitken 2010; Frey et al. 2004; Liebig et al. 2013).

Mit Blick auf die Verteilungsgerechtigkeit ist der Ausbau der erneuerbaren Energien auf lokaler Ebene durch die Asymmetrie von Nutzen und Lasten charakterisiert. Der Nutzen im Sinne der Reduzierung von $\mathrm{CO}_{2}$-Emissionen ist dabei von globalem Interesse, die negativen Umwelteffekte, wie beispielsweise die Störungen des Landschaftsbildes durch Windräder, zeigen sich aber auf lokaler Ebene. Ebenso unausgewogen ist in vielen Fällen die Verteilung des monetären Nutzens: in vielen Fällen profitiert v.a. der externe Investor und die Region hat keinen Anteil an den Erlösen (Lienhoop 2018).

\section{Methodischer Fokus}

Der Einfluss von Verfahrens- und Verteilungsgerechtigkeit auf die lokale Akzeptanz von erneuerbaren Energien wurde bereits in einigen qualitativen (z.B. Christidis et al. 2017; Langer et al. 2016), quantitativen (Walter 2014; Gölz und Wedderhoff 2018) und mixed methods Studien (z.B. Walker und Baxter 2017a, 2017b) sowie experimentellen Studien unter Verwendung von Choice Experimenten (z.B. Lienhoop 2018; Dimitropoulos und Kontoleon 2009) und Faktoriellen Survey Experimenten (Liebe et al. 2017; Walter und Gutscher 2013) untersucht. Aufgrund des normativen Charakters von Gerechtigkeitsurteilen stellt soziale Erwünschtheit häufig ein Problem bei der direkten Messung von Gerechtigkeitseinstellungen dar (Liebig et al. 2015) Der Vorteil von Faktoriellen Survey und Choice Experimenten gegenüber herkömmlichen Item-basierten Befragungen besteht darin, dass sie aufgrund ihres 
experimentellen Charakters und ihrer Multidimensionalität weniger anfällig für Verzerrung aufgrund von sozialer Erwünschtheit sind (Auspurg und Liebe 2011).

Bei beiden Verfahren werden den Befragten Beschreibungen vorgelegt, in denen mehrere Merkmale in ihren Ausprägungen experimentell variiert werden. Ein Faktorielles Survey Experiment umfasst eine oder mehrere Situationsbeschreibungen, die die Befragten je nach Kontext beispielsweise hinsichtlich ihrer Zustimmung oder Ablehnung oder der empfundenen Gerechtigkeit auf einer Rating-Skala bewerten (Auspurg und Liebe 2011). Choice Experimente enthalten in der Regel auch ein monetäres Merkmal und Befragte treffen eine Auswahlentscheidung zwischen mehreren Optionen. Darauf basierend können Präferenzen oder Zahlungsbereitschaften bestimmt werden. Beide Verfahren dienen dazu, den Einfluss der Situationsmerkmale auf die getroffene Bewertung bzw. Auswahlentscheidung zu gewichten (Auspurg et al. 2009) und somit kausale Effekte zu bestimmen (Auspurg und Liebe 2011; Liebig et al. 2015). Faktorielle Survey Experimente werden in unterschiedlichen Kontexten angewendet (Wallander 2009), insbesondere zur Messung von Normen und wahrgenommener Gerechtigkeit (Liebig et al. 2015; Jasso und Opp 1997). Vor dem Hintergrund der dargestellten Zielstellungen der beiden Methoden und des jeweiligen Messinstruments, scheint die Anwendung eines Faktoriellen Survey Experiments zur Messung der Bedeutung von Gerechtigkeitsaspekten im Kontext des Ausbaus der erneuerbaren Energien angemessen (Liebe et al. 2017).

Bisher wurde Gerechtigkeit im Kontext des Ausbaus der erneuerbaren Energien als erklärende Variable für Akzeptanz oder Ablehnung verwendet. Entsprechend den Konzepten der Umweltund Energiegerechtigkeit liegt dabei Gleichheit als Gerechtigkeitsprinzip zugrunde. Jedoch ist zu berücksichtigen, dass eine ungleiche Verteilung von Lasten und Nutzen nicht zwangsläufig ungerecht empfunden wird und andere Gerechtigkeitsprinzipien, wie das Leistungsprinzip oder das Bedarfsprinzip bei der Bewertung zugrunde liegen können (Skitka et al. 2003; Miller 1999; Beatley 1984). Ebenso kann Verfahrensgerechtigkeit in verschiedenen Abstufungen als gerecht empfunden werden.

Im Sinne der empirischen Gerechtigkeitsforschung, die sich mit der Erhebung von Gerechtigkeitsüberzeugungen und der Klärung von Ursachen und Überzeugungen beschäftigt (Liebig 2002), erweitert der Beitrag , Improving research on energy justice by using factorial survey experiments “ in Kapitel V der vorliegenden Dissertation die aktuelle Forschung zur Bedeutung der Gerechtigkeit im Kontext des Ausbaus der erneuerbaren Energien auf lokaler Ebene, indem mit Hilfe eines Faktoriellen Survey Experiments die wahrgenommene 
Gerechtigkeit unterschiedlicher Ausbauszenarien direkt gemessen wird und somit die relative Bedeutung der beiden Gerechtigkeitsdimensionen Verfahrens- und Verteilungsgerechtigkeit bestimmt werden kann.

Die Dissertation schließt in Kapitel VI mit einer Zusammenschau und Diskussion der Ergebnisse.

\section{Literatur}

AEE (Agentur für erneuerbare Energien) (2012): Akzeptanzumfrage 2012. Bürger stehen weiterhin hinter dem Ausbau der erneuerbaren Energien (Renews kompakt). Online verfügbar unter https://www.unendlich-vielenergie.de/media/file/85.aee_RenewsKompakt_Akzeptanzumfrage2012.pdf, zuletzt geprüft am 03.03.2019.

AEE (Agentur für erneuerbare Energien) (2018): Grafik-Dossier zur jährlichen Akzeptanzumfrage der Agentur für Erneuerbare Energien. 93 Prozent der Bevölkerung in Deutschland unterstützen den verstärkten Ausbau Erneuerbarer Energien. Online verfügbar unter https://www.unendlich-vielenergie.de/media/image/28191.AEE_akzeptanzumfrage2018_Unterstuetzung_Ausbau.jpg, zuletzt geprüft am 10.02.2019.

Aitken, Mhairi (2010): Wind power and community benefits. Challenges and opportunities. In: Energy Policy 38 (10), S. 6066-6075. DOI: 10.1016/j.enpol.2010.05.062.

Ajzen, Icek (1991): The theory of planned behavior. In: Organizational Behavior and Human Decision Processes 50 (2), S. 179-211. DOI: 10.1016/0749-5978(91)90020-T.

Andorfer, Veronika A.; Liebe, Ulf (2013): Consumer Behavior in Moral Markets. On the Relevance of Identity, Justice Beliefs, Social Norms, Status, and Trust in Ethical Consumption. In: European Sociological Review 29 (6), S. 1251-1265. DOI: 10.1093/esr/jct014.

Ansolabehere, Stephen; Konisky, David M. (2009): Public Attitudes Toward Construction of New Power Plants. In: Public Opinion Quarterly 73 (3), S. 566-577. DOI: 10.1093/poq/nfp041.

Auspurg, Katrin; Hinz, Thomas; Liebig, Stefan (2009): Komplexität von Vignetten, Lerneffekte und Plausibilität im Faktoriellen Survey. In: Methoden, Daten, Analysen 3 (1), S. 59-96.

Auspurg, Katrin; Liebe, Ulf (2011): Choice-Experimente und die Messung von Handlungsentscheidungen in der Soziologie. In: Kölner Zeitschrift für Soziologie und Sozialpsychologie 63 (2), S. 301-314. DOI: 10.1007/s11577-011-0136-3.

Baxter, Jamie (2017): Energy justice. Participation promotes acceptance. In: Nature Energy 2 (8), 17128. DOI: 10.1038/nenergy.2017.128.

Baxter, Jamie; Morzaria, Rakhee; Hirsch, Rachel (2013): A case-control study of support/opposition to wind turbines. Perceptions of health risk, economic benefits, and community conflict. In: Energy Policy 61, S. 931-943. DOI: 10.1016/j.enpol.2013.06.050. 
Beatley, Timothy (1984): Applying Moral Principles to Growth Management. In: Journal of the American Planning Association 50 (4), S. 459-469. DOI:

10.1080/01944368408976777.

Bell, Derek; Gray, Tim; Haggett, Claire; Swaffield, Joanne (2013): Re-visiting the 'social gap'. Public opinion and relations of power in the local politics of wind energy. In: Environmental Politics 22 (1), S. 115-135. DOI: 10.1080/09644016.2013.755793.

Bickerstaff, Karen (2017): Justice in Energy System Transitions. A synthesis and agenda. In: Ryan B. Holifield, Jayajit Chakraborty und Gordon P. Walker (Hg.): The Routledge handbook of environmental justice. London: Routledge, Taylor \& Francis Group (Routledge handbooks), S. 388-399.

Bidwell, D. (2016): The Effects of Information on Public Attitudes Toward Renewable Energy. In: Environment and Behavior 48 (6), S. 743-768. DOI: 10.1177/0013916514554696.

Blinder, Alan S. (1973): Wage Discrimination. Reduced Form and Structural Estimates. In: The Journal of Human Resources 8 (4), S. 436-455. DOI: 10.2307/144855.

BMU (Bundesministerium für Umwelt, Naturschutz und nukleare Sicherheit) (2018): Klimaschutz in Zahlen. Fakten, Trends und Impulse deutscher Klimapolitik.

BMWi (Bundesministerium für Wirtschaft und Energie) (2015): Erneuerbare Energien in Zahlen. Nationale und internationale Entwicklungen im Jahr 2014.

BMWi (Bundesministerium für Wirtschaft und Energie) (2018): Erneuerbare Energien in Zahlen. Nationale und internationale Entwicklungen im Jahr 2017.

Bosch, Stephan; Peyke, Gerd (2011): Gegenwind für die Erneuerbaren - Räumliche Neuorientierung der Wind-, Solar- und Bioenergie vor dem Hintergrund einer verringerten Akzeptanz sowie zunehmender Flächennutzungskonflikte im ländlichen Raum. In: Raumforschung und Raumordnung 69 (2), S. 105-118. DOI: 10.1007/s13147-011-0082-6.

Brody, Samuel D.; Highfield, Wes; Alston, Letitia (2004): Does Location Matter? In: Environment and Behavior 36 (2), S. 229-250. DOI: 10.1177/0013916503256900.

Christidis, Tanya; Lewis, Geoffrey; Bigelow, Philip (2017): Understanding support and opposition to wind turbine development in Ontario, Canada and assessing possible steps for future development. In: Renewable Energy 112, S. 93-103. DOI: 10.1016/j.renene.2017.05.005.

Clarke, Christopher E.; Bugden, Dylan; Hart, P. Sol; Stedman, Richard C.; Jacquet, Jeffrey B.; Evensen, Darrick T.N.; Boudet, Hilary S. (2016): How geographic distance and political ideology interact to influence public perception of unconventional oil/natural gas development. In: Energy Policy 97, S. 301-309. DOI: 10.1016/j.enpol.2016.07.032.

Cook, John; Oreskes, Naomi; Doran, Peter T.; Anderegg, William R. L.; Verheggen, Bart; Maibach, Ed W. et al. (2016): Consensus on consensus. A synthesis of consensus estimates on human-caused global warming. In: Environmental Research Letters 11 (4), 48002. DOI: 10.1088/1748-9326/11/4/048002.

Dear, Michael (1992): Understanding and Overcoming the NIMBY Syndrome. In: Journal of the American Planning Association 58 (3), S. 288-300. DOI: 10.1080/01944369208975808. 
Devine-Wright, Patrick (2005): Beyond NIMBYism. Towards an integrated framework for understanding public perceptions of wind energy. In: Wind Energy 8 (2), S. 125-139. DOI: 10.1002/we. 124 .

Devine-Wright, Patrick (2009): Rethinking NIMB Yism. The role of place attachment and place identity in explaining place-protective action. In: Journal of Community \& Applied Social Psychology. 19 (6), S. 426-441. DOI: 10.1002/casp.1004.

Diekmann, Andreas; Meyer, Reto (2010): Demokratischer Smog? Eine empirische Untersuchung zum Zusammenhang zwischen Sozialschicht und Umweltbelastungen. In: Kölner Zeitschrift für Soziologie und Sozialpsychologie 62 (3), S. 437-457. DOI: 10.1007/s11577-010-0108-z.

Dimitropoulos, Alexandros; Kontoleon, Andreas (2009): Assessing the determinants of local acceptability of wind-farm investment. A choice experiment in the Greek Aegean Islands. In: Energy Policy 37 (5), S. 1842-1854. DOI: 10.1016/j.enpol.2009.01.002.

Downey, Liam (2006): Using Geographic Information Systems to Reconceptualize Spatial Relationships and Ecological Context. In: American Journal of Sociology 112 (2), S. 567612. DOI: $10.1086 / 506418$.

Ek, Kristina; Söderholm, Patrik (2007): Public Support for Renewable Electricity: The Importance of Policy Framing. In: Carolyn C. Pertsova (Hg.): Ecological economics research trends. New York, NY: Nova Science Publ, S. 83-104.

Elvers, Horst-Dietrich (2011): Umweltgerechtigkeit. In: Matthias Groß (Hg.): Handbuch Umweltsoziologie. Wiesbaden: VS Verlag für Sozialwissenschaften, S. 464-484.

EWI (Energiewirtschaftliches Institut an der Universität zu Köln) (2013): Trendstudie Strom 2022. Belastungstest für die Energiewende.

Festinger, Leon (1957): A theory of cognitive dissonance. Evanston: Row, Peterson.

Frey, Bruno S.; Benz, Matthias; Stutzer, Alois (2004): Introducing Procedural Utility. Not Only What, but Also How Matters. In: Journal of Institutional and Theoretical Economics / Zeitschrift für die gesamte Staatswissenschaft 160 (3), S. 377-401.

Gaede, James; Rowlands, Ian H. (2018): Visualizing social acceptance research. In: Energy Research \& Social Science 40, S. 142-158. DOI: 10.1016/j.erss.2017.12.006.

Gölz, Sebastian; Wedderhoff, Oliver (2018): Explaining regional acceptance of the German energy transition by including trust in stakeholders and perception of fairness as socioinstitutional factors. In: Energy Research \& Social Science 43, S. 96-108. DOI: 10.1016/j.erss.2018.05.026.

Goodchild, M. F.; Anselin, L.; Appelbaum, R. P.; Harthorn, B. H. (2000): Toward Spatially Integrated Social Science. In: International Regional Science Review 23 (2), S. 139-159. DOI: $10.1177 / 016001760002300201$.

Gravelle, Timothy B.; Lachapelle, Erick (2015): Politics, proximity and the pipeline. Mapping public attitudes toward Keystone XL. In: Energy Policy 83, S. 99-108. DOI: 10.1016/j.enpol.2015.04.004.

Gross, Catherine (2007): Community perspectives of wind energy in Australia. The application of a justice and community fairness framework to increase social acceptance. In: Energy Policy 35 (5), S. 2727-2736. DOI: 10.1016/j.enpol.2006.12.013. 
Hildebrand, Jan; Rau, Irina; Schweizer-Ries, Petra (2018): Akzeptanz und Beteiligung - ein ungleiches Paar. In: Lars Holstenkamp und Jörg Radtke (Hg.): Handbuch Energiewende und Partizipation. Wiesbaden: Springer Fachmedien Wiesbaden, S. 195-209.

Hook, Sandra (2018): ,Energiewende': Von internationalen Klimaabkommen bis hin zum deutschen Erneuerbaren-Energien-Gesetz. In: Olaf Kühne und Florian Weber (Hg.): Bausteine der Energiewende. Wiesbaden: Springer Fachmedien Wiesbaden, S. 21-54.

Huijts, N.M.A.; Molin, E.J.E.; Steg, L. (2012): Psychological factors influencing sustainable energy technology acceptance. A review-based comprehensive framework. In: Renewable and Sustainable Energy Reviews 16 (1), S. 525-531. DOI: 10.1016/j.rser.2011.08.018.

IPCC (Intergovernmental Panel on Climate Change) (2015): Climate change 2014. Synthesis report. Unter Mitarbeit von R. K. Pachauri und L. A. L.A. Meyer. Geneva, Switzerland: Intergovernmental Panel on Climate Change. Online verfügbar unter https://www.ipcc.ch/site/assets/uploads/2018/02/SYR_AR5_FINAL_full.pdf, zuletzt geprüft am 13.02.2019.

Jann, Ben (2008): Erwerbsarbeit, Einkommen und Geschlecht. Studien zum Schweizer Arbeitsmarkt. Wiesbaden: VS Verlag für Sozialwissenschaften.

Jasso, Guillermina; Opp, Karl-Dieter (1997): Probing the character of norms. A factorial survey analysis of the norms of political action. In: American Sociological Review 62, S. 947-964.

Jenkins, Kirsten; McCauley, Darren; Heffron, Raphael; Stephan, Hannes; Rehner, Robert (2016): Energy justice. A conceptual review. In: Energy Research \& Social Science 11, S. 174-182. DOI: 10.1016/j.erss.2015.10.004.

Johansson, Maria; Laike, Thorbjörn (2007): Intention to respond to local wind turbines. The role of attitudes and visual perception. In: Wind Energy 10 (5), S. 435-451. DOI: $10.1002 /$ we. 232 .

Jones, Christopher R.; Eiser, Richard J. (2009): Identifying predictors of attitudes towards local onshore wind development with reference to an English case study. In: Energy Policy 37 (11), S. 4604-4614. DOI: 10.1016/j.enpol.2009.06.015.

Kollock, Peter (1998): Social Dilemmas. The Anatomy of Cooperation. In: Annual review of sociology 24 (1), S. 183-214. DOI: 10.1146/annurev.soc.24.1.183.

Kost, Susanne (2013): Transformation von Landschaft durch (regenerative) Energieträger. In: Ludger Gailing und Markus Leibenath (Hg.): Neue Energielandschaften. Neue Perspektiven der Landschaftsforschung. Wiesbaden: Springer Gabler (RaumFragen), S. 121-136.

Ladenburg, Jacob; Möller, Bernd (2011): Attitude and acceptance of offshore wind farmsThe influence of travel time and wind farm attributes. In: Renewable and Sustainable Energy Reviews 15 (9), S. 4223-4235. DOI: 10.1016/j.rser.2011.07.130.

Langer, Katharina; Decker, Thomas; Roosen, Jutta; Menrad, Klaus (2016): A qualitative analysis to understand the acceptance of wind energy in Bavaria. In: Renewable and Sustainable Energy Reviews 64, S. 248-259. DOI: 10.1016/j.rser.2016.05.084.

Leventhal, Gerald S. (1980): What Should Be Done with Equity Theory? In: Kenneth J. Gergen (Hg.): Social exchange. Advances in theory and research. New York: Plenum Press, S. 27-55. 
Liebe, Ulf (2007): Zahlungsbereitschaft für kollektive Umweltgüter. Soziologische und ökonomische Analysen. Wiesbaden: VS, Verlag für Sozialwissenschaften.

Liebe, Ulf; Bartczak, Anna; Meyerhoff, Jürgen (2017): A turbine is not only a turbine. The role of social context and fairness characteristics for the local acceptance of wind power. In: Energy Policy 107, S. 300-308. DOI: 10.1016/j.enpol.2017.04.043.

Liebe, Ulf; Preisendörfer, Peter; Meyerhoff, Jürgen (2011): To Pay or Not to Pay. Competing Theories to Explain Individuals' Willingness to Pay for Public Environmental Goods. In: Environment and Behavior 43 (1), S. 106-130. DOI: 10.1177/0013916509346229.

Liebig, Stefan (2002): Gerechtigkeitseinstellungen und Gerechtigkeitsurteile. Zur Unterscheidung zweier Urteilskategorien. In: Stefan Liebig und Holger Lengfeld (Hg.): Interdisziplinäre Gerechtigkeitsforschung. Zur Verknüpfung empirischer und normativer Perspektiven. Frankfurt/Main: Campus-Verlag, S. 77-102.

Liebig, Stefan; Sauer, Carsten; Friedhoff, Stefan (2015): Using Factorial Surveys to Study Justice Perceptions. Five Methodological Problems of Attitudinal Justice Research. In: Social Justice Research 28 (4), S. 415-434. DOI: 10.1007/s11211-015-0256-4.

Liebig, Stefan; Sauer, Carsten; Valet, Peter (2013): Gerechtigkeit. In: Steffen Mau und Nadine M. Schöneck (Hg.): Handwörterbuch zur Gesellschaft Deutschlands. Wiesbaden: Springer Fachmedien Wiesbaden, 286-299.

Lienhoop, Nele (2018): Acceptance of wind energy and the role of financial and procedural participation. An investigation with focus groups and choice experiments. In: Energy Policy 118, S. 97-105. DOI: 10.1016/j.enpol.2018.03.063.

Logan, John R. (2012): Making a Place for Space: Spatial Thinking in Social Science. In: Annual review of sociology 38. DOI: 10.1146/annurev-soc-071811-145531.

Lucke, Doris (1995): Akzeptanz. Legitimität in der „Abstimmungsgesellschaft“. Opladen: Leske + Budrich.

Mahafza, Zachary B.; Stoutenborough, James W.; Vedlitz, Arnold (2017): The role of proximity in problem identification. Risk of water scarcity in Texas. In: Water Policy 19 (1), S. 86-98. DOI: 10.2166/wp.2016.021.

Marg, Stine; Hermann, Christoph; Hambauer, Verena; Becké, Ana Belle (2013): „Wenn man was für die Natur machen will, stellt man da keine Masten hin“. Bürgerproteste gegen Bauprojekte im Zuge der Energiewende. In: Stine Marg, Lars Geiges, Felix Butzlaff und Franz Walter (Hg.): Die neue Macht der Bürger. Was motiviert die Protestbewegungen?; BP-Gesellschaftsstudie. Reinbek bei Hamburg: Rowohlt, S. 94-138.

McCauley, Darren; Ramasar, Vasna; Heffron, Raphael J.; Sovacool, Benjamin K.; Mebratu, Desta; Mundaca, Luis (2019): Energy justice in the transition to low carbon energy systems. Exploring key themes in interdisciplinary research. In: Applied Energy 233-234, S. 916-921. DOI: 10.1016/j.apenergy.2018.10.005.

Megerle, Heidi (2013): Landschaftsveränderungen durch Raumansprüche erneuerbarer Energien - aktuelle Entwicklungen und Forschungsperspektiven am Beispiel des Ländlichen Raumes in Baden-Württemberg. In: Ludger Gailing und Markus Leibenath (Hg.): Neue Energielandschaften. Neue Perspektiven der Landschaftsforschung. Wiesbaden: Springer Gabler (RaumFragen), S. 145-164. 
Meyer, Reto; Bruderer Enzler, Heidi (2013): Geographische Informationssysteme (GIS) und ihre Anwendung in den Sozialwissenschaften am Beispiel des Schweizer Umweltsurveys. In: Methoden, Daten, Analysen 7 (3), S. 317-346. DOI: 10.12758/mda.2013.016.

Miller, David (1999): Principles of social justice. Cambridge Mass. u.a.: Harvard Univ. Press.

Oaxaca, Ronald (1973): Male-female wage differentials in urban labor markets. In: International Economic Review 14 (3), S. 693-709.

Perlaviciute, Goda; Steg, Linda (2014): Contextual and psychological factors shaping evaluations and acceptability of energy alternatives. Integrated review and research agenda. In: Renewable and Sustainable Energy Reviews 35, S. 361-381. DOI: 10.1016/j.rser.2014.04.003.

Porter, Jeremy R.; Howell, Frank M. (2012): Geographical Sociology. Dordrecht: Springer Netherlands (105).

Read, Darryl L.; Brown, Rhonda F.; Thorsteinsson, Einar B.; Morgan, Methuen; Price, Ian (2013): The theory of planned behaviour as a model for predicting public opposition to wind farm developments. In: Journal of Environmental Psychology 36, S. 70-76. DOI: 10.1016/j.jenvp.2013.07.001.

Schlosberg, David (2007): Defining environmental justice. Theories, movements, and nature. Oxford: Oxford University Press.

Schwartz, Shalom H. (1977): Normative Influences on Altruism. In: Advances in Experimental Social Psychology 10, S. 221-279. DOI: 10.1016/S0065-2601(08)60358-5.

Schweizer-Ries, Petra (2008): Energy sustainable communities. Environmental psychological investigations. In: Energy Policy 36 (11), S. 4126-4135. DOI: 10.1016/j.enpol.2008.06.021.

Skitka, Linda J.; Winquist, Jennifer; Hutchinson, Susan (2003): Are outcome fairness and outcome favorability distinguishable psychological constructs? A meta-analytic review. In: Social Justice Research 16 (4), S. 309-341. DOI: 10.1023/A:1026336131206.

Soland, Martin; Steimer, Nora; Walter, Götz (2013): Local acceptance of existing biogas plants in Switzerland. In: Energy Policy 61, S. 802-810. DOI: 10.1016/j.enpol.2013.06.111.

Sovacool, Benjamin K.; Heffron, Raphael J.; McCauley, Darren; Goldthau, Andreas (2016): Energy decisions reframed as justice and ethical concerns. In: Nature Energy 1, 16024. DOI: 10.1038/nenergy.2016.24.

Swofford, Jeffrey; Slattery, Michael (2010): Public attitudes of wind energy in Texas. Local communities in close proximity to wind farms and their effect on decision-making. In: Energy Policy 38 (5), S. 2508-2519. DOI: 10.1016/j.enpol.2009.12.046.

van der Horst, Dan (2007): NIMBY or not? Exploring the relevance of location and the politics of voiced opinions in renewable energy siting controversies. In: Energy Policy 35 (5), S. 2705-2714. DOI: 10.1016/j.enpol.2006.12.012.

Venables, Dan; Pidgeon, Nick F.; Parkhill, Karen A.; Henwood, Karen L.; Simmons, Peter (2012): Living with nuclear power. Sense of place, proximity, and risk perceptions in local host communities. In: Journal of Environmental Psychology 32 (4), S. 371-383. DOI: 10.1016/j.jenvp.2012.06.003. 
Vorkinn, M.; Riese, H. (2001): Environmental Concern in a Local Context. The Significance of Place Attachment. In: Environment and Behavior 33 (2), S. 249-263. DOI: 10.1177/00139160121972972.

Walker, Chad; Baxter, Jamie (2017a): “It's easy to throw rocks at a corporation”. Wind energy development and distributive justice in Canada. In: Journal of Environmental Policy \& Planning 19 (6), S. 754-768. DOI: 10.1080/1523908X.2016.1267614.

Walker, Chad; Baxter, Jamie (2017b): Procedural justice in Canadian wind energy development. A comparison of community-based and technocratic siting processes. In: Energy Research \& Social Science 29, S. 160-169. DOI: 10.1016/j.erss.2017.05.016.

Wallander, Lisa (2009): 25 years of factorial surveys in sociology. A review. In: Social Science Research 38 (3), S. 505-520.

Walter, Götz (2014): Determining the local acceptance of wind energy projects in Switzerland. The importance of general attitudes and project characteristics. In: Energy Research \& Social Science 4, S. 78-88. DOI: 10.1016/j.erss.2014.09.003.

Walter, Götz; Gutscher, Heinz (2013): Generelle Befürwortung von Windkraftanlagen vor Ort vs. Befürwortung spezifischer Windkraftprojekte: Der Einfluss von Projekt- und Verfahrensparametern. In: Umweltpsychologie 17 (2), S. 124-144.

Warren, Charles R.; Lumsden, Carolyn; O’Dowd, Simone; Birnie, Richard V. (2005): 'Green On Green'. Public perceptions of wind power in Scotland and Ireland. In: Journal of Environmental Planning and Management 48 (6), S. 853-875. DOI: 10.1080/09640560500294376.

Wolsink, Maarten (2007a): Planning of renewables schemes. Deliberative and fair decisionmaking on landscape issues instead of reproachful accusations of non-cooperation. In: Energy Policy 35 (5), S. 2692-2704. DOI: 10.1016/j.enpol.2006.12.002.

Wolsink, Maarten (2007b): Wind power implementation. The nature of public attitudes: Equity and fairness instead of 'backyard motives'. In: Renewable and Sustainable Energy Reviews 11 (6), S. 1188-1207. DOI: 10.1016/j.rser.2005.10.005.

Wolsink, Maarten (2012): Wind power: basic challenge concerning social acceptance. In: Robert A. Meyers (Hg.): Encyclopedia of sustainability science and technology. Bd. 17. New York, NY: Springer (Springer reference), S. 12218-12254.

Wolsink, Maarten (2018): Social acceptance revisited. Gaps, questionable trends, and an auspicious perspective. In: Energy Research \& Social Science 46, S. 287-295. DOI: 10.1016/j.erss.2018.07.034.

Wüste, André; Schmuck, Peter (2013): Social Acceptance of Bioenergy Use and the Success Factors of Communal Bioenergy Projects. In: Hans Ruppert, Martin Kappas und Jens Ibendorf (Hg.): Sustainable Bioenergy Production - An Integrated Approach. Dordrecht: Springer Netherlands, S. 293-318.

Wüstenhagen, Rolf; Wolsink, Maarten; Bürer, Mary Jean (2007): Social acceptance of renewable energy innovation. An introduction to the concept. In: Energy Policy 35 (5), S. 2683-2691. DOI: 10.1016/j.enpol.2006.12.001. 


\title{
II. Decomposing public support for energy policy: What drives acceptance of and intentions to protest against renewable energy expansion in Germany?
}

Ulf Liebe and Geesche M. Dobers

Veröffentlicht in Energy Research \& Social Science 47 (2019): 247-260.

DOI: 10.1016/j.erss.2018.09.004

\begin{abstract}
Based on data from a large-scale survey $(n=3400)$ conducted in Germany, we analyze citizens' acceptance and protest intentions regarding the construction of new power plants for renewable energy production. We differentiate between wind energy, solar energy, and biomass energy; natural gas is used as a reference category. We measure protest intentions and acceptance regarding the construction of new power plants within a 10-kilometer radius of respondents' place of residence. Protest and acceptance are explained by several competing theoretical determinants such as specific attitudes towards each energy source, general attitudes towards climate change, social norms, the "not-in-my-backyard" phenomenon, place attachment, and conditional cooperation. We use decomposition models used in labor market research to study endowment, discrimination, and characteristics effects related to different attitudinal dimensions and their influence on acceptance and protest intentions. Our results show more positive attitudes, less protest intentions, and a stronger acceptance of solar energy, followed by wind energy, biomass energy, and natural gas. Theory comparison reveals, for instance, that "not-in-my-backyard" beliefs have high explanatory power, climate change concern is only relevant for the acceptance of wind energy and solar energy, and place attachment seems to be a useful concept for explaining protest intentions. The decomposition models indicate that attitudes are strong determinants of acceptance and protest intentions where, in addition to endowment effects, we also find some indications of discrimination effects (i.e., different weights of attitudinal dimensions) and characteristics effects (i.e., effects of respondents' characteristics). Finally, we discuss the policy implications of these results.
\end{abstract}

Keywords: Attitudes; conditional cooperation; decomposition models; not-in-my-backyard; place attachment; protest; renewable energy 


\title{
III. Spatial dimension of social acceptance of renewable energies and related infrastructure - a quantitative literature review
}

Geesche M. Dobers

Eingereicht bei Energy Research \& Social Science, im Review-Prozess

\begin{abstract}
In the vast literature on social acceptance of renewable energies, examining the effect of proximity and other spatial information is an important aspect amongst others. Here, we give an overview of this field of research based on 21 journal articles published between 2005 and 2018. Therefore, spatial information, which is integrated into the quantitative analysis of social acceptance, is categorized in two levels of measurement: self-reported exposure and objective measurement of exposure. Proximity and other spatial variables show mixed effects on social acceptance. The use of self-reported exposure clearly dominates in the reviewed studies. However, technical capabilities of geographical information systems (GIS) enable the integration of objective spatial information into the analysis. Future research should put more focus on these tools.
\end{abstract}

Keywords: renewable energies; social acceptance; proximity; spatial information; GIS; exposure 


\section{Introduction}

There is vast and further growing literature about social acceptance of energy technologies, especially concerning renewable energies (REs). For a long time, research in the field of REs has been focusing on examining attitudes towards wind power and discussing and explaining them using the so-called Not-In-My-Backyard concept (NIMBY) (Gaede and Rowlands, 2018). NIMBY implies, that people generally support a technology or infrastructure, however, if a correspondent facility should be built in their vicinity, they refuse it for egoistic reasons (see, e.g., Wolsink, 2007). Meanwhile, scientists more and more agree upon that using the concept of NIMBY as an explanation for rejection is pejorative, too simplistic and lacking empirical evidence (Devine-Wright, 2011, 2005; Carlisle et al., 2016; Perlaviciute and Steg, 2014; Wolsink, 2007).

Nevertheless, the influence of exposure in the sense of proximity and other spatial characteristics on social acceptance of (renewable) energy projects, still appears to be relevant and is of ongoing scientific interest (van der Horst, 2007). The proximity-hypothesis (Dear, 1992; Larson and Krannich, 2016; Swofford and Slattery, 2010), which easily expresses that residents who live closer to a facility are more likely to oppose it, may serve as a starting point. Compared to the NIMBY-approach, this is a more neutral concept with regard to proximity. However, studies integrating proximity into their analysis reveal mixed results (Rand and Hoen, 2017) and show that proximity rather serves as a proxy variable whose content depends on the variety of contexts: Proximity can be an indicator of risk perception intensity, especially in the planning phase of a new facility (Mueller et al., 2017; Nelson et al., 2017), or it can serve as an indicator of experience and familiarity with existing facilities (Haggett, 2011). Next to proximity, further spatial aspects of interest are the visibility of facilities - obviously, closely connected to proximity - (e.g. Ek, 2005; Firestone and Kempton, 2007; Ladenburg, 2008) and cumulative aspects referring to the density of RE plants (e.g. Ladenburg et al., 2013; Ladenburg and Dahlgaard, 2012).

From a methodical point of view, several authors emphasize the technical possibilities and the valuable scientific findings of including spatial information in social sciences. Thus, research analyzing geocoded and spatially linked survey data is growing (Diekmann and Meyer, 2010; Downey, 2006; Goodchild et al., 2000; Logan, 2012; Müller et al., 2017; Porter and Howell, 2012). On the one hand, the technical possibility is given due to geographic information systems (GIS) which enable us to easily assign individuals to space, based on geographic coordinates. On the other hand, spatial data, being more and more available, enables us to include the spatial 
context of social processes and therefore also to examine the effects of the physical environment on attitudes and behavior. Thus, "[s]patial thinking is about where things are and where they happen, and it is especially about where they are in relation to others." (Logan, 2012, p. 508). According to the First Law of Geography, stating that "everything is related, but near things are more related than distant things" (Tobler, 1970: 236), distance is the basic concept of spatial analysis either as "an indicator of access to other people or resources or exposure to harm" (Logan, 2012, p. 511).

In this review article, we want to give an overview on how studies about social acceptance of REs and related infrastructure integrate spatial aspects, especially, but not exclusively, proximity. We expect the field of REs to be a fruitful area for application of spatial aspects, as they represent a widespread and highly spatially relevant development of our time. Against the background of research on social acceptance of REs, we will give a structure to the mixed effects of proximity and other spatial aspects on social acceptance examined so far. With regard to the integration of spatial information in social sciences, we will give an example from the context of REs to highlight promising techniques that should be used more intensively, not only in the field of REs.

This article is structured as follows: in chapter 2 we present all articles that were filtered by our specific search criteria. Thereby, we start with definitions of key terms and describe our selection criteria for the literature search. In the subsequent quantitative literature review, we subdivide the reviewed articles according to the origin of the spatial data integrated in the analysis: subjective and objective spatial data. In chapter 3, we critically assess the current state of knowledge by comparison with studies from adjacent fields and conclude with suggestions for future research.

\section{Empirical quantitative research on spatial dimension in the context of renewable energy and related infrastructure}

\subsection{Underlying literature}

In our literature review, we consider English-language journal articles examining the effect of proximity and other spatial aspects on social acceptance of REs and related infrastructure using quantitative data. The following definitions clarify the scope of our review:

- Spatial aspects: One crucial aspect of research about social acceptance of RE plants is their proximity to residential areas (compare, e.g., Bertsch et al., 2016). However, many studies examine this aspect hypothetically, meaning that they ask for the claimed minimal distance of hypothetical power plants to residential areas (e.g., Bertsch et al., 
2016; Larson and Krannich, 2016; Read et al., 2013). This methodology is not included in the scope of our review. Instead, we only consider 'real' proximity of existing (ex post) or planned (ex ante) RE power plants to respondents of a survey at different levels of accuracy. Furthermore, we do not exclusively consider proximity in the pure sense of distance to RE sites but we also account for different spatially significant aspects of REs such as visibility, audibility, and density.

- Included RE power plants and associated infrastructures: We looked for papers examining RE plants in the open space, hence excluding e.g., solar panels on roofs. Furthermore, we considered papers about HVTL because grid extension is required for energy transition.

- Acceptance: In the literature so far, social acceptance of REs and related infrastructure has been operationalized very differently (see Batel et al., 2013; Busse and Siebert, 2018). Therefore, we applied a broad understanding of acceptance, when collecting the studies examined in this review. Correspondingly, we considered studies that measure acceptance of, general attitudes towards, and opposition against RE and related infrastructure, both on a local level and as a general question.

The articles included result from literature research in ISI Web of Science. Restricted to the Social Science index, we used the following search strings: "renewable energ* OR wind OR solar OR biomass OR biomass OR transmission lines" and "acceptance OR attitude* OR perception OR oppos*” and "proximity OR distance OR exposure OR viewshed". Additionally, we checked the cited literature of the identified articles from web of science. In sum, we found 21 articles to be relevant for this review.

\subsection{Quantitative literature review}

We structure the identified literature twofold, according to the source and the accuracy of the used spatial data (see Table 1). Firstly, we differentiate studies with regard to their source of spatial information about REs and identify two categories: studies using subjective data of exposure (data is self-reported by respondents) and studies using objective data of exposure. Secondly, we differentiate the accuracy of data according to its scale level: binary, nominal, ordinal and continuous. While studies with subjective spatial data cover all four scale levels, studies with objective spatial data comprise binary, ordinal or continuous spatial variables exclusively. 
Table 1: Classification of the reviewed literature.*

\begin{tabular}{|c|c|c|c|c|}
\hline $\begin{array}{l}\text { Measurement of } \\
\text { exposure }\end{array}$ & Spatial variable & Scale level & Energy type & $\begin{array}{l}\text { Number of } \\
\text { studies }\end{array}$ \\
\hline \multirow{5}{*}{$\begin{array}{l}\text { Subjective } \\
\text { (self-reported) }\end{array}$} & $\begin{array}{l}\text { Visibility** (and/ or } \\
\text { audibility) }\end{array}$ & $\begin{array}{l}\text { binary; } \\
\text { nominal }\end{array}$ & Wind & 11 \\
\hline & $\begin{array}{l}\text { Visual } \\
\text { accessability*** }\end{array}$ & ordinal & Wind & 1 \\
\hline & \multirow{2}{*}{ Proximity } & \multirow{2}{*}{ ordinal } & Wind & 2 \\
\hline & & & HVTL & 1 \\
\hline & Density & $\begin{array}{l}\text { Ordinal; } \\
\text { continuous }\end{array}$ & Wind & 5 \\
\hline \multirow{3}{*}{ Objective } & \multirow{2}{*}{ Proximity } & \multirow{2}{*}{$\begin{array}{l}\text { Binary, } \\
\text { ordinal; } \\
\text { continuous }\end{array}$} & Wind & 7 \\
\hline & & & HVTL & 1 \\
\hline & Density & ordinal & HVTL & 1 \\
\hline $\begin{array}{l}\text { Number of } \\
\text { studies }\end{array}$ & & & & 29 \\
\hline
\end{tabular}

* Note: Studies examining more than one spatial variable are counted more than once.

** Refers to visibility from place of residence.

*** Refers to the frequency of seeing a wind energy facility.

Regarding the type of REs, the presented studies are very homogenous: The majority of studies (18) conducts its analysis in the context of wind energy, while only three studies examine the spatial effect of HVTL. However, heterogeneity among the presented studies is found with regard to their setting: some studies examine attitudes towards existing or planned facilities, others looked at attitudes towards additional facilities in the vicinity of respondents without concrete planning and again others investigated general attitudes regarding REs or wind energy. Correspondingly, studies examining a concrete setting (existing or planned facilities) are based on a locally collected data set (except Firestone et al. (2017), they use nationwide geocoded data of wind energy facilities and generate their sample only of residents within $8 \mathrm{~km}$ ). Studies that focus on general attitudes or hypothetical additional developments are able to survey on a nationwide level.

In the following detailed review of selected studies, we start with the presentation of studies from the category "self-reported exposure" and continue with studies from the category "objective measurement of exposure." Within these categories, we order the presented studies according to their scale level. Some studies use several spatial variables from different categories in their analyses. Hence, they are presented more than once, highlighting different 
spatial variables. A detailed overview of all presented studies is given in Table A1 of the appendix.

\subsubsection{Subjective measurement of exposure (self-reported)}

Spatial variables about REs in the vicinity of respondents based on subjective data (altogether 14 studies) largely comprise statements of respondents about the visibility of RE sites from their place of residence (spatial variable visibility; eleven studies out of 14). This information is recorded mostly as a binary variable, however in one study it is captured as a nominal variable (Langer et al., 2018). In this case, authors include additional answer categories such as visibility of a wind energy site "Under construction" and "Under planning procedure." Two studies (Krause et al., 2016; Mulvaney et al., 2013) capture visibility and / or audibility of RE power plants (more exactly wind energy plants) in one variable which is binary coded, too. Three studies offer more precise measures of distance (Langer et al., 2018; Nelson et al., 2017; OlsonHazboun et al., 2016). They consider the self-reported proximity of respondents to a facility, all of them on an ordinal level. Therefore, Nelson et al. (2017) presented a map depicting the planned route of the power line in their questionnaire. They then requested respondents to insert the distance on a five-point answer scale (from $\leq 91 \mathrm{~m}$ to $>3.2 \mathrm{~km}$ ). Langer et al. (2018) collected this information on a metric scale using an open question. However, they used a three-point ordinal scale to integrate the data in their analysis $(0-10 \mathrm{~km} ; 11-500 \mathrm{~km} \text {; not present })^{1}$. OlsonHazboun et al. (2016) use a four-point answer scale (from $<1$ mile to $>10$ miles).

While all studies presented so far tend to cover RE sites in the nearest proximity of respondents, some studies (five out of 14) examine cumulative effects by asking how many wind energy turbines respondents see on a daily basis (spatial variable density). ${ }^{2}$ Four studies (Ladenburg, 2015; Ladenburg et al., 2013; Ladenburg, 2010; Ladenburg and Dahlgaard, 2012) ${ }^{3}$ capture this information on an ordinal scale $(0-5 ; 6-10 ; 11-20 ;>20$; do not recall), while one study (Langer et al., 2018) records the spatial variable density on a continuous scale. Additionally, one study (Olson-Hazboun et al., 2016) examines visual accessibility, meaning how frequently respondents see a turbine, measured on a four-point ordinal scale (from "everyday" to "a few times a year or less").

\footnotetext{
${ }^{1}$ The scale is not consistently specified. Version 1: 0-10; 11-500; not present; version 2: 0-50; 51-500; not present.

${ }^{2}$ Langer et al. (2018) do not specify the context of their density variable, they purely ask "How many turbines do you see?"

${ }^{3}$ Note that except for Ladenburg (2008) all studies under participation of Ladenburg considered in this review use the same dataset.
} 
Looking at the effects of self-reported exposure on attitudes towards REs, we find various results. In six out of eleven studies, the variable visibility does not show significant results. In all six cases, the dependent variable slightly differs: general attitudes towards wind energy (Ek, 2005), intention to oppose additional local wind turbines (Johansson and Laike, 2007), attitudes towards existing wind energy turbines onshore (Ladenburg and Dahlgaard, 2012) and acceptance of hypothetic additional wind energy facilities in the vicinity of respondents (Langer et al., 2018).

Two studies show mixed results. Mulvaney et al. (2013) examine attitudes toward hypothetic additional wind energy turbines in respondents' county. They report that visibility (in this study commonly recorded with audibility) is significant on a bivariate level, but not in the multivariate models. The authors find a lower share of supporters of a wind energy facility in the affected group. It is noteworthy that this study does not differentiate between (expected) visibility and / or audibility of existing and planned wind turbines in defining the variable visibility. Furthermore, in Ladenburg (2010), who examines attitudes towards existing wind energy turbines offshore, only the variable visibility onshore shows a significant positive effect, while the variable visibility offshore does not exert any significant effect.

In three out of eleven studies visibility shows a negative effect on attitudes, once towards a planned offshore wind facility (Firestone and Kempton, 2007), once towards hypothetic additional onshore wind energy turbines (Ladenburg, 2008) and once towards existing local wind energy facilities (Firestone et al., 2017). Two studies present positive effects of visibility. In Krause et al. (2016), respondents living close to existing wind energy turbines (defined by the variable visibility) are more supportive and assess turbines more attractive compared to respondents that do not see a wind energy turbine from their place of residence. Ladenburg (2010) reports a positive effect of visibility of onshore wind energy turbines on attitudes towards offshore turbines.

Three studies integrate the measurement of self-reported proximity in their analysis. Nelson et al. (2017) show a negative effect of proximity on attitudes towards a planned HVTL and a positive effect on oppositional behavior. Langer et al. (2018) also find an effect of their ordinally scaled proximity variable, however, only for the category "no turbines existing in the vicinity." This covariate shows a negative effect on acceptance of hypothetic additional wind energy facilities in the vicinity of respondents. Olson-Hazboun et al. (2016) do not find a significant effect of proximity.

Five studies examine cumulative effects using the variable density and one study using the variable visual accessibility. Thereof, four studies show negative effects on acceptance. Again, 
the differing dependent variable has to be considered: one study (Ladenburg, 2010) examines the effect of density on attitudes toward existing offshore turbines and indicates that respondents who do not recall the number of turbines seen daily show more negative attitudes toward existing wind turbines offshore. The second study (Ladenburg and Dahlgaard, 2012) examines the effect of density on attitudes towards existing onshore turbines (here, results are "not strictly significant in all models"). The third focusses on the effect of density on attitudes towards more onshore turbines, however, "conditional on having a viewshed to turbines" (Ladenburg et al., 2013). The fourth study looks at the effect of visual accessibility on support of local wind energy facilities (Olson-Hazboun et al., 2016). In the latter study, authors do not differentiate between existing and planned wind energy facilities, neither in the dependent nor in the independent variable.

Ladenburg (2015) reports that density enhances the probability of being indifferent between future wind power development onshore or offshore. However, these effects are only weakly significant. Furthermore, Langer et al. (2018) report no significant effects of density on acceptance of hypothetic additional wind energy facilities in the vicinity of respondents.

All in all, our overview shows that the settings and effects of self-reported measures of exposure on social acceptance of REs are rather heterogeneous (see Table 2). Mostly, the variable visibility is used in the reviewed studies. In four out of eleven cases, this variable shows no significant effects. In two studies, visibility shows mixed results (one study reports partly positive, one study reports partly negative effects). Three studies show negative effects and two studies show positive effects of this variable. The number of studies that integrate other subjective spatial variables in their analysis, such as self-reported proximity, density or visual accessibility, is very small. Two thirds of them (six studies out of nine) show negative effects on social acceptance of REs.

We have to take a closer look at the effect of the proximity variable used by Langer et al. (2018), as well as the effect of the density variable used by Ladenburg (2010). In these cases, only the categories "no turbines existing in the vicinity" and "do not recall" significantly affect attitudes toward REs, respectively. In a strict sense, these categories do not adequately display the content of the variable at hand. They could be used as values of a binary variable, recording the existence of facilities in the vicinity of respondents. Used in this way (and hence being a kind of visibility variable), the results rather show a positive effect of existing turbines on attitudes towards REs. This interpretation additionally strengthens the heterogeneity of results. 
Table 2: Effects of subjectively measured spatial variables on social acceptance of REs.*

\begin{tabular}{|c|c|c|c|c|c|c|}
\hline \multirow[t]{2}{*}{ Spatial variable } & \multirow[t]{2}{*}{ Scale level } & \multicolumn{4}{|c|}{ Effects** } & \multirow{2}{*}{$\begin{array}{l}\text { Number } \\
\text { of studies }\end{array}$} \\
\hline & & Positive & Negative & Mixed & $\begin{array}{l}\text { Not } \\
\text { significant }\end{array}$ & \\
\hline \multirow{2}{*}{ Visibility } & binary & 2 & 3 & 2 & 3 & $\overline{10}$ \\
\hline & nominal & & & & 1 & 1 \\
\hline Visual accessibility & ordinal & & 1 & & & 1 \\
\hline Proximity & ordinal & & 2 & & 1 & 3 \\
\hline \multirow{2}{*}{ Denstity } & ordinal & & 3 & & & 3 \\
\hline & continuous & & & & 1 & 1 \\
\hline Number of studies & & 2 & 9 & 2 & $\overline{6}$ & $\overline{19}$ \\
\hline
\end{tabular}

* Note: Studies examining more than one spatial variable are counted more than once.

** As the results of Ladenburg (2015) do not fit to the categories, this study could not be considered in this table.

\subsubsection{Objective measurement of exposure}

Only 43 percent of the reviewed studies (nine out of 21) use objective spatial data about REs in the vicinity of respondents. The majority of studies thereof, examines the effect of the spatial variable proximity, and only one study integrates the spatial variable density in the analysis.

One study measures proximity on a binary scale, four on an ordinal scale and three studies on a continuous scale. The density variable is ordinally scaled, too. The binary proximity variable results from a case-control study (Baxter et al., 2013): the case study comprises residents living within a $15 \mathrm{~km}$-radius from two wind energy developments while the control study results from a community without wind energy facilities in the same radius. The generation of the ordinal proximity variable is done by recruiting survey participants. The starting point is an existing or planned RE site. The study area covers a designated radius around the site. This area is further subdivided, creating buffer zones which encircle the RE site with augmenting radius (Firestone et al., 2017; Johansson and Laike, 2007; Swofford and Slattery, 2010; Warren et al., 2005). The magnitudes of the study areas and their stratification vary in the four studies, ranging from a maximum radius of $8 \mathrm{~km}$ (Firestone et al., 2017) to a maximum radius of 50km (Johansson and Laike, 2007). Swofford and Slattery (2010) define their study area, its stratification and their sampling of survey participants using GIS, hence they had access on spatial data (geographic coordinates) of the energy site and of the addresses of residents. Warren et al. (2005) define their study area and draw their sample "manually." Participants of the face-to-face interviews 
were systematically selected by the interviewers within the buffer zones. Johansson and Laike (2007) easily define the belonging of survey participants to the three buffer zones through the recorded municipality of respondents. In the aforementioned studies, the starting point of data generation of the spatial variable are existing or planned RE sites. Therefore, the scope of the studies is mainly limited to a local level, examining attitudes of residents of a specific facility. Only Firestone et al. (2017) base their study on a huge data set of wind energy facilities in the US.

Three studies measure proximity on a continuous scale (Jacquet, 2012; Ladenburg and Möller, 2011; Mueller et al., 2017) in three different settings: existing offshore windfarms (Ladenburg and Möller, 2011), existing and planned wind farms / natural gas wells (Jacquet, 2012), and planned corridors for HVTL (Mueller et al., 2017). The proximity variable is based on exactly geocoded data of the energy sites and varying spatial information about respondents. Ladenburg and Möller (2011) measure travel time from the centroid of the respondents' postal code area to the nearest offshore wind park using GIS and, thereby, lay their focus on accessibility. The proximity variable of Jacquet (2012) contains the distance from energy sites to the centroids of respondents' property values calculated using GIS. Mueller et al. (2017) manually elaborate the shortest distance from the community of respondents to the nearest corridor of a planned HVTL. Looking at the effects of proximity, we find a positive effect of proximity for the case-control study (Baxter et al., 2013). Residents of the affected communities are more supportive regarding wind energy facilities in their municipality and in their region, respectively. On a bivariate level, evidence for both is found, while on a multivariate level, the former is only partly confirmed (the effect is not consistently significant in all five models presented). Studies using an ordinally scaled variable of proximity show mixed results: Johansson and Laike (2007) do not find a significant influence of proximity. In their descriptive study, Warren et al. (2005) indicate a positive effect of proximity on attitudes towards existing wind farms, while they find a negative effect of proximity on attitudes towards planned wind energy sites. For their Scottish part of the sample (the data stems from case studies in Scotland and Ireland), they find higher support of wind energy and the local wind farm around an operational site, compared to a planned site. Firestone et al. (2017) also find a positive effect of proximity on attitudes towards local wind energy facilities. However, their multivariate regressions do not show this effect in all models presented. Another descriptive study, Swofford and Slattery (2010) report a negative effect of proximity on general attitudes towards wind energy. Additionally, they describe that respondents living in the closest zone to existing wind parks, are willing to support wind farms that are far away (within Texas or in the US but not in their surroundings). Respondents living 
more than five kilometers away from the existing wind farm, are more open regarding future developments of wind farms in their surroundings. Apart from the fact that the results of this study are derived from descriptive statistics, also the unbalanced group sizes in the three different zones can be considered a weakness. In the inner circle, only eight respondents are counted, while the middle and the outer circle, comprise 100 and 85 respondents, respectively. In contrast to the presented effects of the ordinally scaled proximity variable on attitudes towards REs, all three studies that use a continuous proximity variable show its significantly negative effects, at least in parts. More precisely, Ladenburg and Möller (2011) indicate a negative effect of travel time (hence, a positive effect of proximity) on attitudes towards offshore wind farms with a decreasing rate. However, respondents living less than 30 minutes away from an offshore wind farm, display more negative attitudes towards existing offshore wind farms. Jacquet (2012) reports negative effects of proximity on existing and additional wind turbines and gas wells on a bivariate level, respectively. In the multivariate analysis, the effects are only weakly significant for wind energy sites and not at all significant for gas wells. Mueller et al. (2017) show a negative effect of proximity on public support of grid expansion. Further analysis yields similar results and indicates that proximity is related to a higher level of risk perception: proximity exerts positive effects on expected deterioration of the landscape, on expected damages to health and on expected reduction of property values. Furthermore, proximity has a positive effect on the probability of showing oppositional behavior (becoming a member of a local citizens initiative). Exclusively, Mueller et al. (2017) use a logarithmic measure of distance, taking into account the distance decay effect. This effect says that the effect of proximity diminishes with increasing distance as it is "highly localized and not linear" (see Gravelle and Lachapelle, 2015, p.102). Accordingly, the repetition of the analysis with untransformed measures of distance leads to less clear and less significant effects. Similar in their argumentation concerning a non-linear effect of proximity, but different in their implementation, Ladenburg and Möller (2011) include travel time as a linear and a quadratic term in their model. As both covariates show an opposite sign in the analysis (linear: positive; quadratic: negative), they conclude that more remote respondents are more negatively inclined, but with a decreasing rate.

Next to the presented studies integrating a proximity variable as an objective measure of exposure into their analysis, only one study includes an objective measure of density. Soini et al. (2011) define their density variable by recruiting survey participants from three postal code areas affected by existing HVTL to different extents. Their latent class analysis shows that respondents living in an area with most or some HVTL, show a higher probability of being part 
of the latent class with positive or indifferent perceptions. Respondents living in the area without HVTL, tend to be part of the class with either 'rather negative' or 'very negative' perceptions of HTVL.

Besides proximity, Firestone et al. (2017) include further information about the nearest wind energy facilities of respondents as age, height and capacity of turbines, as well as (in case of a wind energy farm) the number of turbines, into the analysis. Their results show a positive effect of age and capacity of turbines on attitudes toward local wind energy facilities. However, a nearest wind farm that comprises more than ten turbines exerts a negative effect.

Taken together, the presented studies using objective measures of exposure also show heterogeneous results (see Table 3). Still, it is noticeable that all three proximity variables that are measured on a continuous scale show negative effects, while the remaining studies using binary or ordinally scaled measures of proximity report varying results. The case-control study using a binary measure finds a positive effect of proximity. The remaining two studies, one integrating density and one integrating characteristics of facilities as explanatory variables in their analysis (the latter is not included in Table 3), show mainly positive effects of exposure to RE on social acceptance.

Table 3: Effects of objectively measured spatial variables on social acceptance of REs.

\begin{tabular}{|c|c|c|c|c|c|c|}
\hline \multirow[t]{2}{*}{ Spatial variable } & \multirow[t]{2}{*}{ Scale level } & \multicolumn{4}{|c|}{ Effects } & \multirow{2}{*}{$\begin{array}{c}\text { Number } \\
\text { of studies }\end{array}$} \\
\hline & & Positive & Negative & Mixed & \begin{tabular}{|l|} 
Not \\
significant
\end{tabular} & \\
\hline \multirow{3}{*}{ Proximity } & binary & 1 & & & & 1 \\
\hline & ordinal & 1 & 1 & 1 & 1 & 4 \\
\hline & continuous & & 3 & & & 3 \\
\hline Denstity & ordinal & 1 & & & & 1 \\
\hline Number of studies & & 3 & 4 & 1 & 1 & 9 \\
\hline
\end{tabular}

\section{Conclusion and research recommendations}

Our review shows, that the effects of proximity and other spatial variables are diverse and that they do not easily confirm the proximity-hypothesis. Rather, proximity implies different factors which form attitudes such as familiarity, local experience and discourse, social and economic benefits of the facility in the case of existing energy sites (Cale and Kromer, 2015; Clarke et al., 2016; Ladenburg and Möller, 2011; Venables et al., 2012) and higher levels of concern due to risk awareness, "feelings of uncertainty, distrust and perceived lack of control" (Venables et 
al., 2012, p. 372) in the case of proposed facilities (Cale and Kromer, 2015; compare Mueller et al., 2017). Gravelle and Lachapelle (2015) suggest "that the spatial distribution of support and opposition will vary according to the spatial distribution of risks and benefits for a particular project" (p. 106). Against this background, it is important to clearly differentiate the purpose of analysis: examining the effect of proximity on existing or proposed facilities, or on general attitudes towards a technology. Research should not only look for an effect of proximity but also for the underlying factors.

Focusing only on studies that use objective spatial data measured on a continuous scale in their analysis, the results of the three presented studies (Jacquet, 2012; Langer et al., 2018; Mueller et al., 2017) are very homogeneous. All three studies show negative effects of proximity on attitudes toward REs. However, we are aware of the fact that three studies are a very small number which is insufficient to assure this effect. Studies in adjacent fields of research show positive relations. Meyerhoff (2013) for instance, conducts a stated preference analysis and thereby integrates the straight distance to the closest wind turbine. The results show that respondents living closer to a wind turbine claim significantly less constraints regarding future wind energy developments in their vicinity. Gravelle and Lachapelle (2015) indicate a significantly negative effect of growing distance to a planned pipeline. Furthermore, there might be a publication bias (Dickersin, 2005; Gerber and Malhotra, 2008) in the sense that both authors and editors prefer to publish results confirming the proximity-hypothesis. It might be helpful to follow Downey (2006), who gives a more general definition of the proximity hypothesis: „Spatial proximity hypotheses can be defined as hypotheses that include geographic distance as a predictor or outcome of some social process.” (p. 576).

Most of the studies presented in our review use self-reported exposure as spatial information in their analysis. However, there are several studies from adjacent fields of research such as nuclear power (e.g., Cale and Kromer, 2015; Venables et al., 2012), fracking (e.g., Clarke et al., 2016), oil pipeline route (Gravelle and Lachapelle, 2015) and stated preferences regarding REs (Meyerhoff, 2013) that give an example for how to get and to use objective and individual measurements of exposure in the analysis. Most of the studies mentioned before use zip code areas' or counties' centroid as a proxy for respondents' place of residence. Only Meyerhoff (2013) uses geocoded data of respondents' address. Hence, research integrating spatial information in the field of REs should use the technical capabilities of GIS and integrate as exact spatial measurements as possible into the analysis as self-reported exposure is highly subjective and largely prone to bias. Priestley and Evans (1996) for instance, report only a low correlation of objective data and subjective statements of visibility. Especially visibility has 
been overestimated by respondents. Furthermore, categorical measurement of distance (distance bands or administrative areas) highly arbitrary and aggregated (Cale and Kromer, 2015; Gravelle and Lachapelle, 2015; Ladenburg et al., 2013; van der Horst, 2007).

In his analysis of spatial relevance of wind energy development in Northern Jutland (Denmark), Möller (2010) shows possibilities of GIS, to analyze spatially relevant characteristics of wind turbines such as visibility, distance, and density. This article can serve as an example for the type of objective figures and information that could be integrated into the analysis of survey data on attitudes regarding REs and related infrastructure. Furthermore, it could be interesting to validate stated visibility of wind turbines with results of a viewshed analysis.

The present research on spatial effects of attitudes toward REs focusses strongly on wind energy, besides some studies about HVTL. Of course, both energy facilities are widely visible due to their height and therefore offer an obvious access in this field of research. However, while wind turbines and HVTL are characterized by their height, solar fields and biogas production require much more surface area and thus exert a high spatial relevance that should be taken into consideration as well.

Regarding geocoded information of survey respondents' place of residence, researchers have to find ways to survey high amounts of exact data (in contrast to the centroid of the community or the postal code area) while safeguarding respondents' privacy at the same time (see Müller et al., 2017). In order to ease research in this field, spatial data of RE facilities should be made available more easily. 


\section{Appendix}

Table A1: Quantitative studies examining the effect of spatial aspects on social acceptance of REs and related infrastructure.

\begin{tabular}{|c|c|c|c|c|c|}
\hline Article & $\begin{array}{l}\text { Energy } \\
\text { type }\end{array}$ & Type of study & Spatial variable & Dependent variable & Results \\
\hline \multicolumn{6}{|c|}{ Self-reported exposure } \\
\hline Ek (2005) & Wind & $\begin{array}{l}\text { Nation-wide } \\
\text { (Sweden) }\end{array}$ & Visibility (binary) & $\begin{array}{l}\text { General attitude towards } \\
\text { wind power }\end{array}$ & n.s. \\
\hline $\begin{array}{l}\text { Firestone } \\
\text { and } \\
\text { Kempton } \\
(2007)\end{array}$ & $\begin{array}{l}\text { Wind } \\
\text { offshore }\end{array}$ & $\begin{array}{c}\text { Local } \\
\text { (US) }\end{array}$ & $\begin{array}{c}\text { Expected visibility (binary): } \\
\circ \text { from home } \\
\circ \text { during daily routine }\end{array}$ & $\begin{array}{l}\text { Support of the planned } \\
\text { development }\end{array}$ & Negative effect \\
\hline $\begin{array}{l}\text { Johansson } \\
\text { and Laike } \\
\text { (2007) }\end{array}$ & $\begin{array}{l}\text { Wind } \\
\text { onshore }\end{array}$ & $\begin{array}{c}\text { Local } \\
\text { (Sweden) }\end{array}$ & Visibility (binary) & $\begin{array}{l}\text { Intention to oppose } \\
\text { additional local wind } \\
\text { turbines }\end{array}$ & n.s. \\
\hline \multirow{2}{*}{$\begin{array}{l}\text { Ladenburg } \\
\text { (2008) }\end{array}$} & \multirow{2}{*}{$\begin{array}{l}\text { Wind } \\
\text { onshore } \\
\text { and } \\
\text { offshore }\end{array}$} & \multirow{2}{*}{$\begin{array}{l}\text { Nation-wide } \\
\text { (Denmark) }\end{array}$} & \multirow{2}{*}{$\begin{array}{l}\text { Visibility onshore and offshore } \\
\text { (binary) }\end{array}$} & $\begin{array}{l}\text { Attitudes towards more } \\
\text { onshore turbines }\end{array}$ & $\begin{array}{l}\text { Visibility onshore and offshore: negative } \\
\text { effect }\end{array}$ \\
\hline & & & & $\begin{array}{l}\text { Attitudes towards more } \\
\text { offshore turbines }\end{array}$ & $\begin{array}{l}\text { Visibility offshore: no effect, but respondents } \\
\text { who have neglected to give a statement are } \\
\text { more negative towards more offshore turbines }\end{array}$ \\
\hline $\begin{array}{l}\text { Ladenburg } \\
(2010)^{*}\end{array}$ & $\begin{array}{l}\text { Wind } \\
\text { offshore }\end{array}$ & $\begin{array}{l}\text { Nation-wide } \\
\text { (Denmark) }\end{array}$ & $\begin{array}{ll}- & \text { Visibility onshore and offshore } \\
\text { (binary) } & \\
\text { - Density (ordinal): number of } \\
\text { turbines seen daily }(0-5,6-10,11- \\
20,>20, \text { do not recall) }\end{array}$ & $\begin{array}{l}\text { Attitudes towards existing } \\
\text { wind turbines offshore }\end{array}$ & $\begin{array}{ll}\text { - } & \text { Visibility offshore: } \text { n.s. } \\
\text { - } & \text { Visibility onshore: positive effect }{ }^{4} \\
\text { - } & \text { Density: "do not recall” negative effect }\end{array}$ \\
\hline
\end{tabular}

${ }^{4}$ Ladenburg and Möller (2011) and Ladenburg (2010) base their analysis on the same dataset. According to Ladenburg and Möller (2011), the main model of Ladenburg (2010) corresponds to Model I in Ladenburg and Möller (2011). However, the results are not consistent. Ladenburg (2010) reports a positive effect of visibility onshore on attitudes towards offshore wind turbines. Ladenburg and Möller (2011) do the same, but their corresponding coefficient (reported in Table 8, p. 4232) is diametrical: the coefficient is positive, but, according to the text (p. 4233), it should be negative. The effects of visibility offshore and density correspond. We suppose that this contradiction is based on a typing error, therefor we only consider Ladenburg (2010) at this point of our review. 
Table A1 (continued): Quantitative studies examining the effect of spatial aspects on social acceptance of REs and related infrastructure.

\begin{tabular}{|c|c|c|c|c|c|}
\hline Article & $\begin{array}{l}\text { Energy } \\
\text { type }\end{array}$ & Type of study & Spatial variable & Dependent variable & Results \\
\hline \multicolumn{6}{|c|}{ Self-reported exposure } \\
\hline $\begin{array}{l}\text { Ladenburg } \\
\text { and } \\
\text { Dahlgaard } \\
(2012)^{*}\end{array}$ & $\begin{array}{l}\text { Wind } \\
\text { onshore }\end{array}$ & $\begin{array}{l}\text { Nation-wide } \\
\text { (Denmark) }\end{array}$ & $\begin{array}{ll}- & \text { Visibility (binary) } \\
- & \text { Density (ordinal): number of } \\
\text { turbines seen daily }(0-5,6-10,11- \\
20,>20, \text { do not recall) }\end{array}$ & $\begin{array}{l}\text { Attitudes towards existing } \\
\text { onshore wind turbines }\end{array}$ & 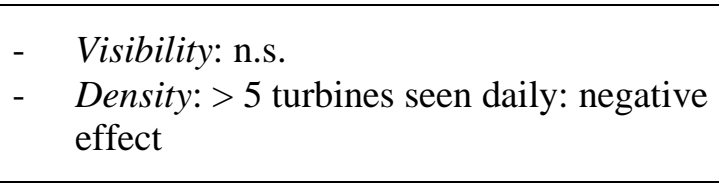 \\
\hline $\begin{array}{l}\text { Ladenburg et } \\
\text { al. }(2013)^{*}\end{array}$ & $\begin{array}{c}\text { Wind } \\
\text { onshore }\end{array}$ & $\begin{array}{l}\text { Nation-wide } \\
\text { (Denmark) }\end{array}$ & $\begin{array}{ll}- & \text { Visibility (binary) } \\
- & \text { Density (ordinal): number of } \\
\text { turbines seen daily }(0-5,6-10,11- \\
20,>20, \text { do not recall) }\end{array}$ & $\begin{array}{l}\text { Attitudes towards more } \\
\text { onshore turbines }\end{array}$ & $\begin{array}{l}\text { - Density: > } 20 \text { turbines seen daily: negative } \\
\text { effect } \\
\text { - Negative effect of density "conditional on } \\
\text { having a viewshed to turbines" }\end{array}$ \\
\hline $\begin{array}{l}\text { Mulvaney et } \\
\text { al. (2013) }\end{array}$ & $\begin{array}{l}\text { Wind } \\
\text { onshore }\end{array}$ & $\begin{array}{c}\text { Local } \\
\text { (US: Indiana) }\end{array}$ & $\begin{array}{l}\text { (expected) visibility and / or audibility } \\
\text { (binary) }\end{array}$ & $\begin{array}{l}\text { Support of wind turbines in } \\
\text { respondents' county }\end{array}$ & $\begin{array}{ll} & \text { Multivariate analysis: n.s. } \\
\text { - } & \text { Bivariate analysis: lower share of } \\
& \text { supporters in the affected group } \\
\end{array}$ \\
\hline $\begin{array}{l}\text { Ladenburg } \\
(2015)^{*}\end{array}$ & $\begin{array}{l}\text { Wind } \\
\text { onshore } \\
\text { and } \\
\text { offshore }\end{array}$ & $\begin{array}{l}\text { Nation-wide } \\
\text { (Denmark) }\end{array}$ & $\begin{array}{l}\text { Density (ordinal): number of turbines } \\
\text { seen daily }(0-5,6-10,11-20,>20 \text {, do } \\
\text { not recall) }{ }^{1}\end{array}$ & $\begin{array}{l}\text { "Relative attitude towards } \\
\text { future wind power } \\
\text { development onshore and } \\
\text { offshore" } \\
\end{array}$ & $\begin{array}{l}\text { "respondents who see more than } 10 \text { turbines } \\
\text { daily have a higher propensity to be } \\
\text { indifferent between more onshore and } \\
\text { offshore wind turbines" }\end{array}$ \\
\hline $\begin{array}{l}\text { Krause et al. } \\
\text { (2016) }\end{array}$ & $\begin{array}{l}\text { Wind } \\
\text { onshore }\end{array}$ & $\begin{array}{c}\text { Local } \\
\text { (US: } \\
\text { Washington } \\
\text { and California) } \\
\end{array}$ & Visibility and / or audibility (binary) & $\begin{array}{l}\text { Group comparison of } \\
\text { support for wind turbine } \\
\text { construction in the US } \\
\text { (hypothetical) }\end{array}$ & $\begin{array}{l}\text { Proximates "are more supportive and express } \\
\text { opinions that turbines are more attractive and } \\
\text { less disturbing" }\end{array}$ \\
\hline $\begin{array}{l}\text { Olson- } \\
\text { Hazboun et } \\
\text { al. (2016) }\end{array}$ & $\begin{array}{c}\text { Wind } \\
\text { onshore }\end{array}$ & $\begin{array}{l}\text { Local } \\
\text { (US: Idaho, } \\
\text { Wyomin, } \\
\text { Utah) }\end{array}$ & $\begin{array}{l}\text { Proximity (ordinal): perceived } \\
\text { distance (in miles) from existing or } \\
\text { planned facilities ( }<1 ; 1-5 ; 5-10 ; \\
>10) \\
\text { visual accessibility (ordinal): } \\
\text { (expected) frequency of seeing a } \\
\text { wind energy facility (every day; a } \\
\text { few times a week; a few times a } \\
\text { month; a few times a year or less) }\end{array}$ & 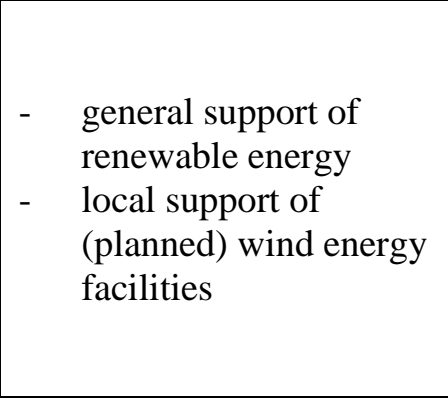 & $\begin{array}{ll}\text { - } & \text { Proximity: } \mathrm{n.s.} \\
\text { - } & \text { negative effect of (expected) visual } \\
\text { accessibility on support of local wind } \\
\text { energy (no differentiation between } \\
\text { existing and planned facilities) }\end{array}$ \\
\hline
\end{tabular}


Table A1 (continued): Quantitative studies examining the effect of spatial aspects on social acceptance of REs and related infrastructure.

\begin{tabular}{|c|c|c|c|c|c|}
\hline Article & $\begin{array}{l}\text { Energy } \\
\text { type }\end{array}$ & Type of study & Spatial variable & Dependent variable & Results \\
\hline \multicolumn{6}{|c|}{ Self-reported exposure } \\
\hline $\begin{array}{l}\text { Nelson et al. } \\
\text { (2017) }\end{array}$ & HVTL & $\begin{array}{l}\text { Local } \\
\text { (US: } \\
\text { California) }\end{array}$ & $\begin{array}{l}\text { Proximity (ordinal): perceived distance } \\
\text { (in } \mathrm{km} \text { ) from the proposed route } \\
(<.091 ; .092-.365 ; .366-1.6 ; 1.6-3.2 \\
>3.2)\end{array}$ & $\begin{array}{l}\text { - Attitudes towards the } \\
\text { planned power line } \\
\text { - Oppositional behavior }\end{array}$ & $\begin{array}{l}\text { - Negative effect of proximity on attitudes } \\
\text { - Positive effect of proximity on behavior } \\
\text { to oppose }\end{array}$ \\
\hline $\begin{array}{l}\text { Firestone et } \\
\text { al. (2017) }\end{array}$ & $\begin{array}{c}\text { Wind } \\
\text { onshore }\end{array}$ & $\begin{array}{c}\text { Nation-wide } \\
(\mathrm{US})^{5}\end{array}$ & Visibility (binary) & $\begin{array}{l}\text { Attitude towards local wind } \\
\text { energy facilities }\end{array}$ & Negative effect \\
\hline $\begin{array}{l}\text { Langer et al. } \\
\text { (2018) }\end{array}$ & $\begin{array}{l}\text { Wind } \\
\text { onshore }\end{array}$ & $\begin{array}{l}\text { Nation-wide } \\
\text { (Germany) }\end{array}$ & $\begin{array}{l}\text { Visibility (nominal): yes; under } \\
\text { construction; under planning } \\
\text { procedure; no } \\
\text { Density (continuous): number of } \\
\text { turbines in the vicinity } \\
\text { - Proximity (ordinal): perceived } \\
\text { distance (in km) to existing } \\
\text { turbines (0-10; 11-500; not } \\
\text { present) }\end{array}$ & $\begin{array}{l}\text { Acceptance of wind energy } \\
\text { close to respondents' place } \\
\text { of residence (hypothetical) }\end{array}$ & $\begin{array}{l}\text { - Visibility: n.s. } \\
\text { - Density: n.s. } \\
\text { - } \\
\text { Proximity: n.s., however "in areas with } \\
\text { no wind turbines people tend to not } \\
\text { accept wind energy" }\end{array}$ \\
\hline \multicolumn{6}{|c|}{ Objective measurement of exposure } \\
\hline $\begin{array}{l}\text { Warren et al. } \\
(2005)\end{array}$ & $\begin{array}{l}\text { Wind } \\
\text { onshore } \\
\text { (local) }\end{array}$ & $\begin{array}{l}\text { Local } \\
\text { (Scotland and } \\
\text { Ireland) }\end{array}$ & $\begin{array}{l}\text { Proximity (ordinal): Distance bands (in } \\
\mathrm{km}) \text { to existing /planned wind farms } \\
(0-5,5-10,10-20)\end{array}$ & $\begin{array}{ll}\text { - } & \text { Attitudes towards } \\
\text { existing / planned local } \\
\text { wind farms } \\
\text { - } \\
\text { Attitudes towards wind } \\
\text { energy }\end{array}$ & $\begin{array}{l}\text { Attitudes towards existing wind farms: } \\
\text { positive effect } \\
\text { - Attitudes towards planned wind farm: } \\
\text { negative effect }\end{array}$ \\
\hline $\begin{array}{l}\text { Johansson } \\
\text { and Laike } \\
(2007)\end{array}$ & $\begin{array}{l}\text { Wind } \\
\text { onshore } \\
\text { (local) }\end{array}$ & $\begin{array}{c}\text { Local } \\
\text { (Sweden) }\end{array}$ & $\begin{array}{l}\text { Proximity (ordinal): Distance bands (in } \\
\mathrm{km}) \text { to two existing turbines }(<3,3-5 \text {, } \\
<50)\end{array}$ & $\begin{array}{l}\text { Intention to oppose } \\
\text { additional local wind } \\
\text { turbines }\end{array}$ & n.s. \\
\hline
\end{tabular}

\footnotetext{
${ }^{5}$ The sample only comprises respondents who live $8 \mathrm{~km}$ from an existing wind turbine at most.
} 
Table A1 (continued): Quantitative studies examining the effect of spatial aspects on social acceptance of REs and related infrastructure.

\begin{tabular}{|c|c|c|c|c|c|}
\hline Article & \begin{tabular}{|l} 
Energy \\
type
\end{tabular} & Type of study & Spatial variable & Dependent variable & Results \\
\hline \multicolumn{6}{|c|}{ Objective measurement of exposure } \\
\hline $\begin{array}{l}\text { Baxter et al. } \\
\text { (2013) }\end{array}$ & $\begin{array}{l}\text { Wind } \\
\text { onshore }\end{array}$ & $\begin{array}{l}\text { Local } \\
\text { (Canada: } \\
\text { Ontario) }\end{array}$ & $\begin{array}{l}\text { Proximity (binary): communities with } \\
\text { turbines in } 15 \mathrm{~km} \text { radius (case study) } \\
\text { against a matched control without } \\
\text { turbines }\end{array}$ & $\begin{array}{l}\text { Support for regional and } \\
\text { local wind turbines }\end{array}$ & Positive effect \\
\hline $\begin{array}{l}\text { Swofford } \\
\text { and Slattery } \\
\text { (2010) }\end{array}$ & $\begin{array}{l}\text { Wind } \\
\text { onshore }\end{array}$ & $\begin{array}{l}\text { Local } \\
\text { (US: Texas) }\end{array}$ & $\begin{array}{l}\text { Proximity (ordinal): distance bands (in } \\
\mathrm{km}) \text { to an existing wind farm }(<5,5- \\
10,10-20)\end{array}$ & \begin{tabular}{|ll}
- & general attitudes to \\
wind energy \\
- & willingness to support \\
& wind farms \\
\end{tabular} & Negative effect \\
\hline $\begin{array}{l}\text { Ladenburg } \\
\text { and Möller } \\
(2011)^{*}\end{array}$ & $\begin{array}{l}\text { Wind } \\
\text { offshore }\end{array}$ & $\begin{array}{l}\text { Nation-wide } \\
\text { (Denmark) }\end{array}$ & $\begin{array}{l}\text { Proximity (continuous): Travel } \\
\text { time: place of residence (proxy: } \\
\text { postal district centroid) to nearest } \\
\text { offshore wind farm } \\
\text { - Density (continuous): Number of } \\
\text { turbines of the nearest wind farm } \\
\text { offshore }\end{array}$ & $\begin{array}{l}\text { Attitude towards existing } \\
\text { wind farms offshore }\end{array}$ & $\begin{array}{l}\text { Proximity: Negative, not linear effect of } \\
\text { travel time, travel time <30min: negative } \\
\text { effect } \\
\text { - Density: positive effect }\end{array}$ \\
\hline $\begin{array}{l}\text { Soini et al. } \\
\text { (2011) }\end{array}$ & HVTL & $\begin{array}{l}\text { Local } \\
\text { (Finland) }\end{array}$ & $\begin{array}{l}\text { Density (ordinal): three postal code } \\
\text { areas differently affected from } \\
\text { transmission lines: } \\
-\quad \text { no } \\
-\quad \text { some } \\
-\quad \text { most transmission lines of the } \\
\text { region }\end{array}$ & Perception of power lines & Positive effect \\
\hline
\end{tabular}


Table A1 (continued): Quantitative studies examining the effect of spatial aspects on social acceptance of REs and related infrastructure.

\begin{tabular}{|c|c|c|c|c|c|}
\hline Article & \begin{tabular}{|l|}
$\begin{array}{l}\text { Energy } \\
\text { type }\end{array}$ \\
\end{tabular} & Type of study & Spatial variable & Dependent variable & Results \\
\hline \multicolumn{6}{|c|}{ Objective measurement of exposure } \\
\hline $\begin{array}{l}\text { Jacquet } \\
(2012)\end{array}$ & $\begin{array}{l}\text { Wind } \\
\text { onshore } \\
\text { and } \\
\text { natural } \\
\text { gas }\end{array}$ & $\begin{array}{c}\text { Local } \\
\text { (US: } \\
\text { Pennsylvania) }\end{array}$ & $\begin{array}{l}\text { Proximity (continuous): distance from } \\
\text { the center of respondent's property to } \\
\text { the nearest wind turbine / natural gas } \\
\text { well }\end{array}$ & $\begin{array}{l}\text { Attitude towards existing } \\
\text { /additional wind farm / } \\
\text { natural gas development }\end{array}$ & 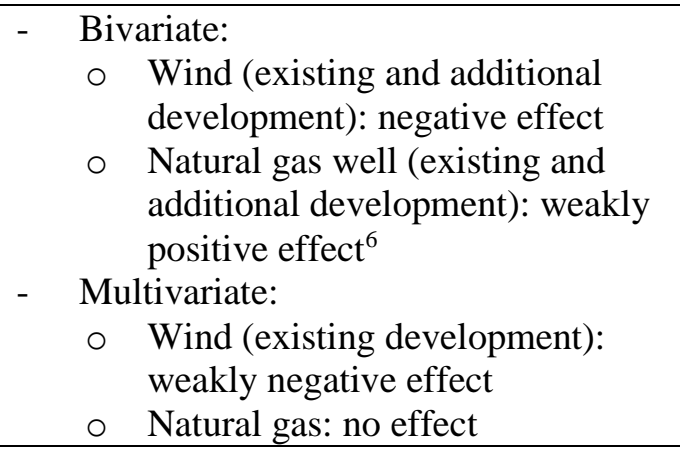 \\
\hline $\begin{array}{l}\text { Firestone et } \\
\text { al. (2017) }\end{array}$ & $\begin{array}{l}\text { Wind } \\
\text { onshore }\end{array}$ & $\begin{array}{l}\text { Nation-wide } \\
\text { (US) }\end{array}$ & $\begin{array}{l}\text { Proximity (ordinal): distance bands } \\
\text { (in km) to existing wind energy } \\
\text { sites }(<0.8 ; 0.8-1.6 ; 1.6-4.8 ; 4.8-8) \\
\text { Further characteristics of the } \\
\text { closest wind facilities: age, height, } \\
\text { installed capacity, }>10 \text { turbines } \\
\end{array}$ & $\begin{array}{l}\text { Attitude towards local wind } \\
\text { energy facilities }\end{array}$ & $\begin{array}{l}\text { Proximity: partly, positive effect, other } \\
\text { n.s. } \\
\text { - Further characteristics: age: positive } \\
\text { effect; height: n.s.; capacity: positive } \\
\text { effect; >10 turbines: negative effect }\end{array}$ \\
\hline
\end{tabular}

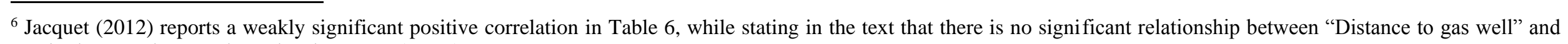
"Attitude towards natural gas development" (p.685) 
Table A1 (continued): Quantitative studies examining the effect of spatial aspects on social acceptance of REs and related infrastructure.

\begin{tabular}{|c|c|c|c|c|c|}
\hline Article & \begin{tabular}{|l|} 
Energy \\
type
\end{tabular} & Type of study & Spatial variable & Dependent variable & Results \\
\hline \multicolumn{6}{|c|}{ Objective measurement of exposure } \\
\hline $\begin{array}{l}\text { Mueller et } \\
\text { al. (2017) }\end{array}$ & HVTL & $\begin{array}{c}\text { Local } \\
\text { (Germany) }\end{array}$ & $\begin{array}{l}\text { Proximity (continuous): shortest } \\
\text { distance from respondents' community } \\
\text { to the nearest "transmission line } \\
\text { corridor alternative" }\end{array}$ & $\begin{array}{ll}- & \text { Public support for grid } \\
\text { - } & \begin{array}{l}\text { Expension } \\
\text { of the landscape }\end{array} \\
- & \begin{array}{l}\text { Expected reduction of } \\
\text { property values }\end{array} \\
- & \text { Expected damage to } \\
\text { health } & \text { Membership of local } \\
\text { citizens' initiatives }\end{array}$ & $\begin{array}{ll}\text { - } & \text { Public support: negative effect } \\
\text { - } & \text { landscape deterioration: positive effect } \\
\text { - } & \text { damage to health: positive effect } \\
\text { - } & \text { reduction property values: positive effect } \\
\text { - } & \text { information seeking: positive effect } \\
\text { - } & \text { citizens' initiatives: positive effect }\end{array}$ \\
\hline
\end{tabular}

* Note: All studies base on the same dataset. 


\section{References}

Batel, S., Devine-Wright, P., Tangeland, T., 2013. Social acceptance of low carbon energy and associated infrastructures: A critical discussion. Energy Policy 58, 1-5.

10.1016/j.enpol.2013.03.018.

Baxter, J., Morzaria, R., Hirsch, R., 2013. A case-control study of support/opposition to wind turbines: Perceptions of health risk, economic benefits, and community conflict. Energy Policy 61, 931-943. 10.1016/j.enpol.2013.06.050.

Bertsch, V., Hall, M., Weinhardt, C., Fichtner, W., 2016. Public acceptance and preferences related to renewable energy and grid expansion policy: Empirical insights for Germany. Energy 114, 465-477. 10.1016/j.energy.2016.08.022.

Busse, M., Siebert, R., 2018. Acceptance studies in the field of land use-A critical and systematic review to advance the conceptualization of acceptance and acceptability. Land Use Policy 76, 235-245. 10.1016/j.landusepol.2018.05.016.

Cale, T., Kromer, M., 2015. Does proximity matter? Plant location, public awareness, and support for nuclear energy. The Social Science Journal 52, 148-155. 10.1016/j.soscij.2015.01.002.

Carlisle, J.E., Solan, D., Kane, S.L., Joe, J., 2016. Utility-scale solar and public attitudes toward siting: A critical examination of proximity. Land Use Policy 58, 491-501. 10.1016/j.landusepol.2016.08.006.

Clarke, C.E., Bugden, D., Hart, P.S., Stedman, R.C., Jacquet, J.B., Evensen, D.T.N., Boudet, H.S., 2016. How geographic distance and political ideology interact to influence public perception of unconventional oil/natural gas development. Energy Policy 97, 301-309. 10.1016/j.enpol.2016.07.032.

Dear, M., 1992. Understanding and Overcoming the NIMBY Syndrome. Journal of the American Planning Association 58, 288-300. 10.1080/01944369208975808.

Devine-Wright, P., 2005. Beyond NIMBYism: Towards an integrated framework for understanding public perceptions of wind energy. Wind Energy 8, 125-139. 10.1002/we. 124 .

Devine-Wright, P., 2011. Place attachment and public acceptance of renewable energy: A tidal energy case study. Journal of Environmental Psychology 31, 336-343.

10.1016/j.jenvp.2011.07.001.

Dickersin, K., 2005. Publication bias: recognizing the problem, understanding its origins and scope, and preventing harm, in: Rothstein, H., Sutton, A.J., Borenstein, M. (Eds.), Publication bias in meta-analysis. Prevention, assessment and adjustments. Wiley, Chichester, England, Hoboken, NJ, pp. 11-33.

Diekmann, A., Meyer, R., 2010. Demokratischer Smog? Eine empirische Untersuchung zum Zusammenhang zwischen Sozialschicht und Umweltbelastungen. Köln Z Soziol 62, 437457. 10.1007/s11577-010-0108-Z.

Downey, L., 2006. Using Geographic Information Systems to Reconceptualize Spatial Relationships and Ecological Context. American Journal of Sociology 112, 567-612. $10.1086 / 506418$. 
Ek, K., 2005. Public and private attitudes towards "green" electricity: The case of Swedish wind power. Energy Policy 33, 1677-1689. 10.1016/j.enpol.2004.02.005.

Firestone, J., Hoen, B., Rand, J., Elliott, D., Hübner, G., Pohl, J., 2017. Reconsidering barriers to wind power projects: Community engagement, developer transparency and place. Journal of Environmental Policy \& Planning 20, 370-386. 10.1080/1523908X.2017.1418656.

Firestone, J., Kempton, W., 2007. Public opinion about large offshore wind power: Underlying factors. Energy Policy 35, 1584-1598. 10.1016/j.enpol.2006.04.010.

Gaede, J., Rowlands, I.H., 2018. Visualizing social acceptance research. Energy Research \& Social Science 40, 142-158. 10.1016/j.erss.2017.12.006.

Gerber, A.S., Malhotra, N., 2008. Publication Bias in Empirical Sociological Research: Do Arbitrary Significance Levels Distort Published Results? Sociological Methods \& Research 37, 3-30. 10.1177/0049124108318973.

Goodchild, M.F., Anselin, L., Appelbaum, R.P., Harthorn, B.H., 2000. Toward Spatially Integrated Social Science. International Regional Science Review 23, 139-159. $10.1177 / 016001760002300201$.

Gravelle, T.B., Lachapelle, E., 2015. Politics, proximity and the pipeline: Mapping public attitudes toward Keystone XL. Energy Policy 83, 99-108. 10.1016/j.enpol.2015.04.004.

Haggett, C., 2011. Understanding public responses to offshore wind power. Energy Policy 39, 503-510. 10.1016/j.enpol.2010.10.014.

Jacquet, J.B., 2012. Landowner attitudes toward natural gas and wind farm development in northern Pennsylvania. Energy Policy 50, 677-688. 10.1016/j.enpol.2012.08.011.

Johansson, M., Laike, T., 2007. Intention to respond to local wind turbines: The role of attitudes and visual perception. Wind Energy 10, 435-451. 10.1002/we.232.

Krause, R.M., Pierce, J.C., Steel, B.S., 2016. The Impact of Auditory and Visual Experience with Wind Turbines on Support for Wind Production and Proximity-Based Opposition. Society \& Natural Resources 29, 1452-1466. 10.1080/08941920.2016.1171936.

Ladenburg, J., 2008. Attitudes towards on-land and offshore wind power development in Denmark; choice of development strategy. Renewable Energy 33, 111-118. 10.1016/j.renene.2007.01.011.

Ladenburg, J., 2010. Attitudes towards offshore wind farms-The role of beach visits on attitude and demographic and attitude relations. Energy Policy 38, 1297-1304. 10.1016/j.enpol.2009.11.005.

Ladenburg, J., 2015. Does more wind energy influence the choice of location for wind power development? Assessing the cumulative effects of daily wind turbine encounters in Denmark. Energy Research \& Social Science 10, 26-30. 10.1016/j.erss.2015.06.005.

Ladenburg, J., Dahlgaard, J.-O., 2012. Attitudes, threshold levels and cumulative effects of the daily wind-turbine encounters. Applied Energy 98, 40-46.

10.1016/j.apenergy.2012.02.070. 
Ladenburg, J., Möller, B., 2011. Attitude and acceptance of offshore wind farms-The influence of travel time and wind farm attributes. Renewable and Sustainable Energy Reviews 15, 4223-4235. 10.1016/j.rser.2011.07.130.

Ladenburg, J., Termansen, M., Hasler, B., 2013. Assessing acceptability of two onshore wind power development schemes: A test of viewshed effects and the cumulative effects of wind turbines. Energy 54, 45-54. 10.1016/j.energy.2013.02.021.

Langer, K., Decker, T., Roosen, J., Menrad, K., 2018. Factors influencing citizens' acceptance and non-acceptance of wind energy in Germany. Journal of Cleaner Production 175, 133144. 10.1016/j.jclepro.2017.11.221.

Larson, E.C., Krannich, R.S., 2016. “A Great Idea, Just Not Near Me!”: Understanding Public Attitudes About Renewable Energy Facilities. Society \& Natural Resources 29, 1436-1451. 10.1080/08941920.2016.1150536.

Logan, J.R., 2012. Making a Place for Space: Spatial Thinking in Social Science. Annual review of sociology 38. 10.1146/annurev-soc-071811-145531.

Meyerhoff, J., 2013. Do turbines in the vicinity of respondents' residences influence choices among programmes for future wind power generation? Journal of Choice Modelling 7, 5871. 10.1016/j.jocm.2013.04.010.

Möller, B., 2010. Spatial analyses of emerging and fading wind energy landscapes in Denmark. Land Use Policy 27, 233-241. 10.1016/j.landusepol.2009.06.001.

Mueller, C.E., Keil, S.I., Bauer, C., 2017. Effects of spatial proximity to proposed highvoltage transmission lines: Evidence from a natural experiment in Lower Saxony. Energy Policy 111, 137-147. 10.1016/j.enpol.2017.09.023.

Müller, S., Schweers, S., Siegers, P., GESIS - Leibniz-Institut für Sozialwissenschaften, 2017. Geocoding and spatial linking of survey data: an introduction for social scientists. GESIS Papers 15, Köln. http://nbn-resolving.de/urn:nbn:de:0168-ssoar-52316-9.

Mulvaney, K.K., Woodson, P., Prokopy, L.S., 2013. A tale of three counties: Understanding wind development in the rural Midwestern United States. Energy Policy 56, 322-330. 10.1016/j.enpol.2012.12.064.

Nelson, H.T., Swanson, B., Cain, N.L., 2017. Close and Connected: The Effects of Proximity and Social Ties on Citizen Opposition to Electricity Transmission Lines. Environment and Behavior 50, 567-596. 10.1177/0013916517708598.

Olson-Hazboun, S.K., Krannich, R.S., Robertson, P.G., 2016. Public views on renewable energy in the Rocky Mountain region of the United States: Distinct attitudes, exposure, and other key predictors of wind energy. Energy Research \& Social Science 21, 167-179. 10.1016/j.erss.2016.07.002.

Perlaviciute, G., Steg, L., 2014. Contextual and psychological factors shaping evaluations and acceptability of energy alternatives: Integrated review and research agenda. Renewable and Sustainable Energy Reviews 35, 361-381. 10.1016/j.rser.2014.04.003.

Porter, J.R., Howell, F.M., 2012. Geographical Sociology. Springer Netherlands, Dordrecht.

Priestley, T., Evans, G.W., 1996. Resident Perceptions of a Nearby Electric Transmission Line. Journal of Environmental Psychology 16, 65-74. 10.1006/jevp.1996.0006. 
Rand, J., Hoen, B., 2017. Thirty years of North American wind energy acceptance research: What have we learned? Energy Research \& Social Science 29, 135-148. 10.1016/j.erss.2017.05.019.

Read, D.L., Brown, R.F., Thorsteinsson, E.B., Morgan, M., Price, I., 2013. The theory of planned behaviour as a model for predicting public opposition to wind farm developments. Journal of Environmental Psychology 36, 70-76. 10.1016/j.jenvp.2013.07.001.

Soini, K., Pouta, E., Salmiovirta, M., Uusitalo, M., Kivinen, T., 2011. Local residents' perceptions of energy landscape: The case of transmission lines. Land Use Policy 28, 294305. 10.1016/j.landusepol.2010.06.009.

Swofford, J., Slattery, M., 2010. Public attitudes of wind energy in Texas: Local communities in close proximity to wind farms and their effect on decision-making. Energy Policy 38, 2508-2519. 10.1016/j.enpol.2009.12.046.

van der Horst, D., 2007. NIMBY or not? Exploring the relevance of location and the politics of voiced opinions in renewable energy siting controversies. Energy Policy 35, 2705-2714. 10.1016/j.enpol.2006.12.012.

Venables, D., Pidgeon, N.F., Parkhill, K.A., Henwood, K.L., Simmons, P., 2012. Living with nuclear power: Sense of place, proximity, and risk perceptions in local host communities. Journal of Environmental Psychology 32, 371-383. 10.1016/j.jenvp.2012.06.003.

Warren, C.R., Lumsden, C., O’Dowd, S., Birnie, R.V., 2005. 'Green On Green': Public perceptions of wind power in Scotland and Ireland. Journal of Environmental Planning and Management 48, 853-875. 10.1080/09640560500294376.

Wolsink, M., 2007. Wind power implementation: The nature of public attitudes: Equity and fairness instead of 'backyard motives'. Renewable and Sustainable Energy Reviews 11, 1188-1207. 10.1016/j.rser.2005.10.005. 


\title{
IV. Acceptance of biogas plants taking into account space and place
}

\author{
Geesche M. Dobers
}

Eingereicht bei Energy Policy

\begin{abstract}
As part of Germany's energy transition, enormous efforts are being made to transform the German energy supply to renewable energies. While much of the energy supply from renewables is wind and solar power, biogas is heavily state subsidized in order to balance fluctuation in supply. The transformation to renewable energies leads to notable landscape changes that should be taken into consideration when studying the acceptance of renewable energy plants. We do this by adding spatial information to data from an online survey $(\mathrm{N}=942)$ questioning the acceptance of biogas plants. The density of and distance to existing biogas plants as well as the intensity of maize cultivation in the vicinity of respondents is integrated into the analysis together with more conventional influencing factors such as place attachment and attitudes. Results show that attitudes have the strongest explanatory power but spatial variables, particularly maize intensity, contribute significantly, too. Place attachment does not show reliable effects. The results demonstrate that spatial data can be useful in the analysis of survey data, for instance, in an environmental context. They also show that diversification of the raw materials used for fermentation in biogas plants might be an important factor in improving their acceptance.
\end{abstract}

Keywords: acceptance, biogas, maize, GIS, place attachment, spatial data 


\section{Introduction}

The political agenda in Germany is both to phase out nuclear power by 2022 and to dramatically reduce $\mathrm{CO}_{2}$ emissions. In order to achieve these goals, the German government decided to progressively secure energy supply from renewable energies (REs) and so the Renewable Energy Sources Act (Erneuerbare-Energien-Gesetz - EEG) came into force in 2000. In 2025, at least 40 percent of gross electricity consumption should be provided by REs and at least 80 percent in 2050. The main sources of power generation from REs in 2017 were onshore wind energy, photovoltaics, and biogas contributing 41 percent, 18 percent and 13 percent, respectively (BMWi, 2018). The extension of REs in order to reduce climate gas emissions is a widespread measure taken in the EU and globally, whereas the high share of biogas in REs is a German phenomenon. This development is based on the EEG and its amendments in 2004 and 2009 which stipulated that plant operators using renewable raw materials (2004) and manure (2009) receive financial incentives. This has led to a considerable increase in biogas plants (BGPs) and biogas has become an additional main pillar of the agricultural sector. Simultaneously, the rising number of BGPs caused a change in land use. Since maize is the most efficient vegetable raw fiber, 73 percent of renewable raw materials used in agricultural BGPs is maize (DBFZ, 2015). As a result, the share of silage maize in total arable land also increased considerably: while in 2005 this share amounted to seven percent, it was approximately 12 percent by 2013 (destatis, 2016, 2012). Consequently, competition for land use has strengthened and the landscape has changed considerably in some regions.

A public opinion poll among German residents in 2018 revealed that 63 percent of respondents supported a RE site close to their place of residence but only 40 percent supported a BGP in their vicinity (AEE, 2018b). Compared to wind and solar energy plants, the level of acceptance of a BGP is substantially lower and the cultivation of maize is also viewed somewhat critically (BMU and BfN, 2016). In the public discourse, the increased maize cultivation is predominantly discussed as a problem involving especially ecological aspects. Further important topics are economic and political aspects while ethical and landscape aesthetic aspects are considered to be less relevant (Linhart and Dhungel, 2013).

Despite the high level of overall support for REs (AEE, 2018a), problems of acceptance and emerging protest accompany many specific RE developments (Marg et al., 2013). In the quest for explanations of this "social gap" (Bell et al., 2013), there is a growing consensus in scientific literature that what is known as the not-in-my-backyard (NIMBY) explanation for rejection is pejorative, too simplistic, and lacking empirical evidence (Devine-Wright, 2011, 2005; Carlisle 
et al., 2016; Perlaviciute and Steg, 2014; Wolsink, 2007). In their literature review, Perlaviciute and Steg (2014) give an overview of the numerous influencing factors in the evaluation of energy alternatives. Essentially, they distinguish between contextual characteristics of energy alternatives and psychological factors shaping the evaluations and acceptability of energy alternatives. We follow this line of argumentation and include psychological factors and spatial aspects to explain the acceptance or nonacceptance of BGPs.

One the one hand, contextual factors such as objective changes in space are taken into account as emerged or emerging BGPs and the associated increased cultivation of maize give rise to landscape changes. On the other hand, the individual perception of space and its individual meaning are also included by adapting the concept of place attachment. Furthermore, attitudes to power generation from biomass and maize cultivation are accounted for in order to capture individual evaluations of this energy alternative (cf. Ansolabehere and Konisky, 2009). The present study is based on data from an online survey conducted in two different regions in Germany (northwestern and central-southern Germany) in 2013. Unlike many other studies on REs, it is not a case study but, rather, it examines the acceptance of a hypothetical BGP development in the vicinity of respondents' place of residence. On the basis of geocoded data on respondents' approximate place of residence, the survey data is combined with spatial information about land use (share of maize cultivation in total agricultural land) and existing BGPs in the respondents' vicinity using geographic information systems (GIS). While there is a growing number of scientific studies in the field of REs integrating existing spatial aspects into their analysis (see Section 2 below), the present study is one of a marginal number of studies to date using GIS and, consequently, precise information about the spatial context (e.g. Meyerhoff, 2013; Mueller et al., 2017). To the best of our knowledge, ours is the first study to do so in the context of biogas. Biogas is particularly attractive for GIS analysis as it has two different spatially relevant aspects to it, namely locations of BGPs and maize cultivation.

The present study has two main aims: first, it contributes to the literature by examining the acceptance of BGPs as this RE source has been somewhat neglected to date. As a novelty in this field, not only does the study take into account the BGP itself as a reason for controversy but it also includes the cultivation of maize and related problems in public discourse. Second, using geocoded survey data, it aims to further elaborate the effect of space and spatial characteristics in energy siting controversies.

The paper is structured as follows. We begin with a literature review concerning previous research about acceptance of BGPs and studies taking into account space and place in the 
context of acceptance of (renewable) energies. Subsequently, we express our theoretical expectations. After the description of data and methods we present our key findings. Finally, the results are discussed and the limitations identified.

\section{Literature Review}

\subsection{Theoretical framework and definition of acceptance}

Wüstenhagen et al. (2007) define in their conceptual framework three areas of research in the field of REs' acceptance: (1) on the most general level "socio-political acceptance," (2) "community acceptance" referring to influencing factors of specific siting decisions, and (3) "market acceptance" referring to market adoption of products related to REs. Accordingly, our study which examines factors that influence the acceptance of BGPs belongs to research in the field of "community acceptance."

Following Schweizer-Ries (2008) we define acceptance as a two-dimensional concept that encompasses valuation and action. Corresponding to attitude formation in general (Eagly and Chaiken, 1998), the valuation of an acceptance object (e.g., a BGP) takes place on a cognitive, affirmative and behavioral level by an acceptance subject and is influenced by the acceptance context in which object and subject are embedded (Lucke, 1995; Schweizer-Ries, 2008). Adding action as the second dimension of acceptance we can distinguish passive from active acceptance or nonacceptance and define four basic types: approval (positive valuation and passive behavior), support (positive evaluation and active behavior), ignorance (negative valuation and passive behavior), and resistance (negative valuation and active behavior). Due to the limited options of "normal citizens" for active acceptance we apply a broad definition of acceptance including active and passive acceptance (Schweizer-Ries, 2008).

\subsection{Acceptance of biogas (plants)}

There is only a small number of scientific studies to date examining the acceptance of biogas and related siting controversies (cf. Radics et al., 2015). One reason may be the comparably low level of operation of BGPs on a global level. Compared to other RE sources, most studies reveal relatively limited support of biogas technology (see Borchers et al., 2007 for the U.S., for Germany BMU and BfN, 2016). However, Soland et al. (2013) present a relatively high level of local acceptance of existing BGPs in Switzerland. Focusing their analysis on aspects of justice, they identify distributive justice (measured as perceived costs and benefits) as a key driver for acceptance. In a longitudinal study, Kortsch et al. (2015) examine the acceptance of 
BGPs in four different villages in eastern Germany with plants already in operation. The authors identify regional and individual benefits as well as acceptance of REs at a general level as positive predictors and risk perception as negative predictors for local acceptance of BGP. Additionally, they present qualitative results showing associated negative and positive aspects of biomass use. Frequently mentioned negative aspects are monocultures, annoyance due to smell, traffic, and noise, hazards for nature, and competition for food production. In contrast, the positive aspects mentioned most are favorable economic effects, effective use of resources, and environmentally friendly energy. Noticeably, the negative aspects are predominant and their relative frequency is growing over time. To a large extent, the reported results of the mixed methods study by Schumacher and Schultmann (2017) on acceptance of BGPs among residents living within a $1 \mathrm{~km}$ radius from existing BGPs are similar to those of Kortsch et al. (2015). Furthermore, Schumacher and Schultmann (2017) ask for the claimed minimum distance of a BGP and report that in the German subsample, only 18.5 percent of respondents accept a BGP within a $1 \mathrm{~km}$ radius from their place of residence. ${ }^{1}$ Using a similar question but very different data from a nationwide representative survey in Germany, Bertsch et al. (2016) report contradicting results: 40 percent of respondents accept a BGP in their direct vicinity $(<1 \mathrm{~km})$. Since the sample of Bertsch et al. (2016) is not restricted to residents of existing BGPs, Schumacher and Schultmann (2017) argue that the more critical view in their study might be caused by negative experiences with BGPs due to "noise and traffic, changes of rural landscapes, and potential odor nuisances" (Schumacher and Schultmann, 2017, p. 2407).

\subsection{Increasing maize cultivation in Germany and associated problems}

Particularly due to the EEG, silage maize cultivation in Germany increased from about seven percent of total agricultural area in 2005 to 12 percent in 2012: since then, just a slight increase to nearly 13 percent in 2016 could be observed (destatis, 2016, 2014, 2012). In 2015, roughly 0.9 million hectares were used for cultivation of silage maize for biogas generation (FNR, 2015). This development has been a controversial issue in the German public sphere, with much debate using the keyword "Vermaisung," meaning an unreasonable and threatening increase of maize cultivation. Linhart and Dhungel (2013) analyze public discourse related to this topic and find a prevailing critical view on the development. They indicate that ecological issues in particular are relevant in the debate (monoculture, threat to fauna and water bodies), followed

\footnotetext{
${ }^{1}$ However, this statement is contradictory to the reported results that around 30 percent of German respondents rate the $\mathrm{BGP}$ in their neighborhood positively.
} 
by economic concerns (rising prices for land and food), and political, ethical, and landscape aesthetical arguments. A second discourse analysis (Herbes et al., 2014) based on publications from 2011 to 2013 shows that the topic is still relevant in public debates and critical views continue to predominate.

\subsection{Place attachment}

"Place attachment involves positively experienced bonds, sometimes occurring without awareness, that are developed over time from the behavioral, affective, and cognitive ties between individuals and/or groups and their sociophysical environment." (Brown and Perkins, 1992, p. 284). Devine-Wright (2009) proposes to interpret RE projects as a disruption to place and therefore a threat to place identity. Consequently, protest occurs as place-protective actions. He emphasizes the need to consider place attachment when seeking to explain opposition to RE projects.

Studies to date have shown varying results regarding place attachment and its effect on acceptance of RE developments. Vorkinn and Riese (2001) study the example of a proposed hydropower station and find a negative effect of place attachment on attitudes toward the hydropower development. Conversely, a case study on an existing tidal energy project by Devine-Wright (2011) reveals a positive correlation between place attachment and acceptance of the power station. Devine-Wright and Howes (2010) examine perceptions of an offshore wind farm in two adjacent towns. Based on a slightly higher level of place attachment, bivariate analysis shows a negative correlation between project evaluation and place attachment for the more prosperous of the two towns as well as a positive effect of place attachment on oppositional behavior. In sum, the study does not provide uniform results, indicating that "evaluations of change to places are diverse" (Devine-Wright and Howes, 2010, p. 278). The authors conclude that place attachment does not necessarily lead to place-protective actions. Venables et al. (2012) examine attitudes toward the construction of a new nuclear power station at an existing local site. Interestingly, the variable "power station related sense of place" that means "a perception that the existing power station [...] contributes to the local place-related identity" (Venables et al., 2012, p. 380) is the most powerful covariate. However, there is no significant effect of "regular" sense of place.

Against the background of these opposing results, Carrus et al. (2014) refer to people's local perspective when evaluating RE siting issues. While generally a positive link between place attachment and pro-environmental behavior is assumed, particularly in the case of RE siting, 
opposing a project can be pro-environmental from a local perspective (for instance, in order to protect local biodiversity). Furthermore, local economic interests may also be detrimental to global environmental goals.

\subsection{Spatial information}

Several authors emphasize that spatial information can contribute valuable findings to social science research, referring to technological advances that make this possible (Diekmann and Meyer, 2010; Downey, 2006; Goodchild et al., 2000; Logan, 2012; Porter and Howell, 2012). One the one hand, GIS allows us to easily localize individuals or objects. On the other hand, due to the increasing availability of spatial data, we are able to consider the spatial context of social processes and to examine the effect of the physical environment on attitudes and behavior. While research in the field of human ecology first took geographic factors into account back in the 1920s, in the field of environmental sociology and psychology there is increasing interest in their effects on environmental perceptions, attitudes, and behavior nowadays (Brody et al., 2004). The basic concept of this spatial approach is distance, either serving as "an indicator of access to other people or resources or [as] exposure to harm" (Logan, 2012, p. 511).

Studies integrating spatial information can be found in various fields. Brody et al. (2004) examine the effect of proximity on environmental awareness of and concern for water bodies. Other examples are studies in environmental justice (Diekmann and Meyer, 2010), environmental risk (Mahafza et al., 2017), and energy siting in general (Clarke et al., 2016; Gravelle and Lachapelle, 2015; Venables et al., 2012) as well as siting of RE plants (see below). We expect taking space into account in the field of REs to be fruitful as these are a widespread and highly spatially relevant development.

There is only a limited number of studies on attitudes toward or acceptance of REs that take a spatial dimension into account. Most of them consider wind energy and some others highvoltage transmission lines. They mainly focus on measuring proximity but some studies also account for density. While some studies in the field of acceptance of BGPs hypothetically ask for the claimed minimal distance to accept a BGP in respondents' vicinity (Bertsch et al., 2016; Schumacher and Schultmann, 2017), there are no studies to date integrating "real" spatial information about BGPs in their analysis of acceptance.

Studies of spatial aspects on acceptance of RE differ with regard to the source of spatial data. Accordingly, they can be divided into two categories: self-reported exposure (for example, 
visibility of wind energy turbines from respondents' place of residence) (e.g., Ek 2005; Firestone et al., 2017; Ladenburg, 2008; Langer et al., 2018; Nelson et al., 2017) and objective measurement of exposure (for example, measurements of distance to RE plants based on objective spatial information) (e.g., Ladenburg and Möller, 2011; Soini et al., 2011; Warren et al., 2005). Furthermore, spatial data integrated in the analysis can be categorized according to its scale level which is strongly related to its accuracy. There are studies using binary data (e.g., Baxter et al., 2013; Ek, 2005; Ladenburg, 2008), one study using nominal data (Langer et al., 2018), several studies using ordinal data (e.g., Firestone et al., 2017; Johansson and Laike, 2007; Swofford and Slattery, 2010; Warren et al., 2005), and three studies using continuous data (Jacquet, 2012; Ladenburg and Möller, 2011; Mueller et al., 2017). Overall, the majority of studies shows negative effects of proximity, particularly the three studies using continuous data. However, the settings of the studies are very diverse, examining attitudes toward REs in general or toward a specific RE project, ex post or ex ante. Consequently, it is not possible to recognize a clear direction for this effect of space.

\subsection{Theoretical expectations}

On the basis of the literature presented above, three main possible influencing factors on acceptance were identified: attitudes, place attachment, and spatial characteristics (see Table $1)$.

Table 1: Overview of derived influencing factors and expected effects.

\begin{tabular}{|ll|c|}
\hline Influencing factor & $\begin{array}{l}\text { Expected effects on acceptance of a BGP } \\
\text { development in respondents' vicinity }\end{array}$ \\
\hline 1 & $\begin{array}{l}\text { Attitudes toward power generation } \\
\text { from biomass } \\
\end{array}$ & positive \\
\hline 2 & Attitudes toward maize cultivation & positive \\
\hline 3 & Spatial variables & negative \\
& Distance to BGP & unclear \\
& Density of BGP & unclear \\
& Intensity of maize cultivation & unclear \\
\hline
\end{tabular}

Regarding attitudes toward power generation from biomass and maize cultivation, the expected positive relationship is intuitive and confirmed by the literature. However, the findings of existing studies on the influence of place attachment in energy siting vary depending on the specific situation. Carrus et al. (2014) point out that although place attachment is normally 
connected to environmentally friendly behavior, it may cause refusal behavior with regard to RE developments as local environmental concerns outweigh global concerns. With this in mind, we expect a negative effect of place attachment on new developments of BGPs nearby.

Concerning influencing factors, the literature reviewed underlines the relevance of spatial characteristics in the analysis of public attitudes toward controversial energy siting. However, the review also shows that further research in this field is still required due to the lack of geocoded data (place of residence of respondents) and of large-scale studies. The effects of space on acceptance of energy developments presented are diverse and research in this field is still on an explorative level. Consequently, we are unable to formulate a direction of effect at this stage.

\section{Materials and Methods}

We analyzed data from a nationwide online survey about attitudes to the expansion of REs in Germany. The interviews were conducted in September and October 2013. Respondents were members of an online panel. The data comprises 3,400 completed interviews. The response rate (pursuant to standard RR1 of AAPOR (2016)) amounts to 27.9 percent. On the basis of the installed capacity of power generation from wind and biogas in 2011 available for zip code districts (Netztransparenz.de, 2012), two highly affected regions were determined in preparation for the survey and a disproportionately high number of interviews were conducted in these regions. One region was in northwestern Germany (parts of Lower Saxony and North Rhine-Westphalia), the other in central-southern Germany (parts of Bavaria and BadenWuerttemberg).

Both areas show structural differences: while Bavaria has the highest number of BGPs in Germany, the highest installed capacity of power generation from biogas is in Lower Saxony. Baden-Wuerttemberg and North Rhine-Westphalia follow in positions three and five, respectively, in terms of the number of BGPs and in positions four and five, respectively, in terms of the installed capacity (3N, 2014). The study at hand is limited to the data from the two core regions described. Otherwise, preparation and control of spatial data would have been too cumbersome. Overall, 956 interviews were completed, the adjusted sample comprises 942 interviews (484 for the northern region and 458 for the southern region). Table 2 provides details of the sample. While the main sample $(\mathrm{N}=3,400)$ was quoted for gender and age, women are slightly underrepresented in the sample from the core regions. The deviation may result from the fact that this subsample was not drawn randomly from the main sample. The higher 
share of respondents living in rural areas is a result of the definition of our core regions since the installed capacity of power generation from wind energy and biogas is mainly situated in rural areas. It should be noted that there is a high proportion of highly educated respondents. This is at least partly due to the survey method. ${ }^{2}$

Table 2: Sample description.

\begin{tabular}{|l|r|r|r|r|}
\hline Characteristic & \multicolumn{1}{l|}{$\begin{array}{l}\text { Full } \\
\text { sample }\end{array}$} & \multicolumn{1}{l|}{ North } & \multicolumn{1}{l|}{ South } & \multicolumn{1}{|l|}{$\begin{array}{l}\text { German } \\
\text { population }^{\text {a }}\end{array}$} \\
\hline Number of respondents & 942 & 484 & 458 & \\
\hline Share of women (in \%) & 47.24 & 44.21 & 50.44 & 51.02 \\
\hline Age in years (average) & 43.82 & 45.22 & 42.34 & 44.2 \\
\hline $\begin{array}{l}\text { Share of respondents with university-entrance } \\
\text { diploma or higher (in \%) }\end{array}$ & 50.74 & 51.03 & 50.44 & 28.7 \\
\hline Share of respondents living in rural areas (in \%) & 38.85 & 42.15 & 35.37 & 23.1 \\
\hline
\end{tabular}

Source: ${ }^{\text {a }}$ destatis (2018)

To allow us to capture respondents' place of residence, we asked them to mark an arbitrary point in their immediate vicinity on Google Maps. A small deviation from the actual place of residence was required in order to guarantee data privacy. A total of 97.6 percent of respondents in the core regions answered this question. As for the remaining respondents, their approximate place of residence could be determined by using the centroid of their zip code area via GIS.

Table 3 gives an overview of the influencing factors derived from the literature and shows the wording of the corresponding items in our survey. Attitudes toward power generation from biomass were formulated on the basis of Ansolabehere and Konisky (2009), while attitudes toward maize cultivation refer to the public discussion presented by Linhart and Dhungel (2013). There is a wide variety of conceptual models defining place attachment and a high heterogeneity in its measurement. We elaborated our items following Soini et al. (2012), Vorkinn and Riese (2001), and Devine-Wright (2013). However, due to space restrictions within the questionnaire, we had to limit the number of items measuring place attachment to four. Since landscape changes caused by REs are fundamental to our study, all items refer to landscape aspects.

\footnotetext{
2 The data originate from an online panel which is actively recruited by phone and representative of the German population that uses the internet at least once a week. This subpopulation is characterized by a higher educational level since there is a positive correlation between education and internet usage.
} 
Table 3: Summary of independent variables resulting from the survey (N=942).

\begin{tabular}{|c|c|c|c|c|}
\hline & Influencing factors and related variables & Scale & Mean (SD) & Factor loading \\
\hline 1 & \multicolumn{3}{|l|}{ Attitudes toward power generation from biomass ${ }^{\mathrm{a}}$} & Alpha: $0.701^{\mathrm{b}}$ \\
\hline $1 \mathrm{a}$ & $\begin{array}{l}\text { How costly or cheap do you think it is to produce electricity } \\
\text { with each of the following REs or rather natural gas? }\end{array}$ & $\begin{array}{l}1=\text { very costly; } 2=\text { rather costly; } 3=\text { rather cheap; } 4= \\
\text { very cheap }\end{array}$ & $\begin{array}{r}2.452 \\
(0.729)\end{array}$ & 0.576 \\
\hline $1 \mathrm{~b}$ & $\begin{array}{l}\text { How harmful or harmless to the environment do you think } \\
\text { each of the following power sources is? }\end{array}$ & $\begin{array}{l}1=\text { very harmful; } 2=\text { rather harmful; } 3=\text { rather } \\
\text { harmless; } 4=\text { very harmless }\end{array}$ & $\begin{array}{r}2.379 \\
(0.786)\end{array}$ & 0.787 \\
\hline $1 \mathrm{c}$ & $\begin{array}{l}\text { How enriching or detrimental for the landscape do you think } \\
\text { it is to produce electricity with each of the following REs or } \\
\text { rather natural gas? }\end{array}$ & $\begin{array}{l}1=\text { very detrimental; } 2=\text { rather detrimental; } 3=\text { rather } \\
\text { enriching; } 4=\text { very enriching }\end{array}$ & $\begin{array}{r}2.084 \\
(0.654)\end{array}$ & 0.671 \\
\hline $1 \mathrm{~d}$ & $\begin{array}{l}\text { All in all: To what extent do you think it makes sense to } \\
\text { produce electricity with each of the following REs or rather } \\
\text { natural gas? }\end{array}$ & $\begin{array}{l}1=\text { doesn't make sense at all; } 2=\text { doesn't make much } \\
\text { sense; } 3=\text { makes sense; } 4=\text { makes a lot of sense }\end{array}$ & $\begin{array}{r}2.589 \\
(0.893)\end{array}$ & 0.829 \\
\hline 2 & \multicolumn{2}{|l|}{ Attitudes toward maize cultivation } & & Alpha: 0.809 \\
\hline $2 \mathrm{a}$ & $\begin{array}{l}\text { Maize cultivation has negative impacts on the natural } \\
\text { scenery. }\end{array}$ & \multirow{4}{*}{$\begin{array}{c}1=\text { completely agree, } 2=\text { rather agree, } 3=\text { rather } \\
\text { disagree, } 4=\text { completely disagree }\end{array}$} & $\begin{array}{r}2.592 \\
(0.9853)\end{array}$ & 0.732 \\
\hline $2 b$ & $\begin{array}{l}\text { Agricultural areas should be used to grow food and not to } \\
\text { produce raw materials for energy generation. }\end{array}$ & & $\begin{array}{r}1.809 \\
(0.830)\end{array}$ & 0.737 \\
\hline $2 \mathrm{c}$ & $\begin{array}{l}\text { The increased cultivation of energy crops destroys animal } \\
\text { and plant habitats. }\end{array}$ & & $\begin{array}{r}1.907 \\
(0.832)\end{array}$ & 0.795 \\
\hline $2 \mathrm{~d}$ & $\begin{array}{l}\text { Quality of ground water deteriorates due to the increased } \\
\text { cultivation of energy crops. }\end{array}$ & & $\begin{array}{r}2.244 \\
(0.845)\end{array}$ & 0.759 \\
\hline $2 \mathrm{e}$ & $\begin{array}{l}\text { I approve of arable land being used for the cultivation of } \\
\text { energy crops such as maize. }\end{array}$ & $\begin{array}{l}1=\text { completely disagree, } 2=\text { rather disagree, } 3=\text { rather } \\
\text { agree, } 4=\text { completely agree }\end{array}$ & $\begin{array}{r}2.153 \\
(0.859)\end{array}$ & 0.751 \\
\hline
\end{tabular}

Notes:

${ }^{a}$ In addition, respondents evaluated wind and solar energy as well as natural gas.

b Alpha calculated without the item "How costly or cheap...?" 
Table 3 (continued): Summary of independent variables resulting from the survey (N=942).

\begin{tabular}{|c|c|c|c|c|}
\hline & Influencing factors and related variables & Scale & Mean (SD) & Factor loading \\
\hline 3 & Place attachment & & & Alpha: $0.783^{c}$ \\
\hline $3 a$ & I like to be in the landscape next to my place of residence. & \multirow{4}{*}{$\begin{array}{c}1=\text { completely disagree, } 2=\text { rather disagree, } 3= \\
\text { rather agree, } 4=\text { completely agree }\end{array}$} & $\begin{array}{r}3.610 \\
(0.574)\end{array}$ & 0.839 \\
\hline $3 b$ & $\begin{array}{l}\text { Often, I spend my free time in the landscape next to my place } \\
\text { of residence. }\end{array}$ & & $\begin{array}{r}3.394 \\
(0.691)\end{array}$ & 0.824 \\
\hline $3 \mathrm{c}$ & The landscape around my place of residence is a part of mine. & & $\begin{array}{r}3.189 \\
(0.793)\end{array}$ & 0.794 \\
\hline $3 \mathrm{~d}$ & $\begin{array}{l}\text { It is very important to me that the landscape around my place } \\
\text { of residence does not change. }\end{array}$ & & $\begin{array}{r}3.161 \\
(0.690)\end{array}$ & 0.621 \\
\hline
\end{tabular}

Notes:

"Alpha calculated without the item "It is very important to me that the landscape around my place of residence does not change." 
Table 4: Summary of spatial variables $(\mathrm{N}($ full sample $)=942 ; \mathrm{N}($ north $)=484 ; \mathrm{N}($ south $)=458)$.

\begin{tabular}{|c|c|c|c|c|}
\hline Spatial variable & Min & Max & Mean & $\begin{array}{l}\text { Standard } \\
\text { deviation }\end{array}$ \\
\hline \multicolumn{5}{|l|}{ Distance (in $\mathrm{km}$ ) to nearest BGP: distance to $B G P^{\mathrm{a}}$} \\
\hline Full sample & 0.00 & 11.22 & 3.07 & 2.08 \\
\hline North & 0.05 & 10.47 & 2.96 & 1.89 \\
\hline South & 0.00 & 11.22 & 3.19 & 2.26 \\
\hline \multicolumn{5}{|l|}{ Number of BGPs: density of $B G P^{*, a}$} \\
\hline Full sample & 0 & 41 & 9.30 & 6.35 \\
\hline North & 0 & 41 & 9.42 & 5.71 \\
\hline South & 0 & 34 & 9.16 & 6.97 \\
\hline \multicolumn{5}{|l|}{$\begin{array}{l}\text { Share of maize cultivation (in \%) in total agricultural } \\
\text { area: maize intensity*,b }\end{array}$} \\
\hline Full sample & 2.26 & 53.96 & 17.60 & 10.03 \\
\hline North & 2.26 & 53.96 & 19.89 & 12.15 \\
\hline South & 3.22 & 33.32 & 15.17 & 6.28 \\
\hline
\end{tabular}

Source: ${ }^{\mathrm{a}}$ LANUV, 2017; ML Niedersachsen, 2016; StMWi, 2017 LUBW, 2016; ${ }^{\mathrm{b}}$ LSN, 2012, BKG, 2013

Note: ${ }^{*}$ Referring to $10 \mathrm{~km}$ radius of respondents.

Table 4 shows the spatial variables used in the analysis. For existing BGPs in the vicinity of respondents, two different measures - distance and density - are used. All positions of BGPs have been checked visually using satellite pictures from Google Maps, Google Earth, Bing Maps, and digital orthophotos of the federal states (as far as these are available) as data inspection of the original dataset had revealed inconsistences. The currentness of data on BGPs corresponds to that of the survey data.

The share of maize cultivation in total agricultural area is the calculated weighted mean using data on the municipal level from the agricultural census. Since detailed agricultural data on this spatial level is only collected about every ten years, we had to use data from 2010.

\section{Results}

\subsection{Descriptive Results}

Just over than half of respondents oppose the construction of a new BGP in their vicinity (Table 5) Correspondingly, most respondents view power generation from biomass negatively and, in particular, BGPs are rated as rather or very detrimental by more than 75 percent (Table 3, item 1c). Nevertheless, the majority (56.5 percent) evaluates power generation from biomass as rather making sense or making a lot of sense (item 1d). Apart from the impact of maize cultivation on the natural scenery, which is not rated as problematic by the majority (item 2a), the remaining evaluation of maize cultivation is sharply critical and negative. Regarding the above-mentioned items, the Mann-Whitney test results in statistically significant differences 
between respondents from the north and south: the share of supporters of a new BGP in their vicinity is higher in the south (51 percent versus 38 percent in the north; $\mathrm{p}=0.000$ ). ${ }^{3}$ Similarly, attitudes toward power generation from biomass and toward maize cultivation are more positive in the south. Statistically significant differences are found for the distributions of the variables 1b (north: 37 percent; south: 50 percent; $\mathrm{p}=0.0002$ ) 1c (north: 18 percent; south: 28 percent; $\mathrm{p}=0.0001$ ) and 1d (north: 51 percent; south: 62 percent; $\mathrm{p}=0.0001$ ) and 2a (north: 54 percent; south: 65 percent; $\mathrm{p}=0.0007$ ) and $2 \mathrm{e}$ (north: 30 percent; south: 35 percent; $\mathrm{p}=0.0210)$. Variables measuring place attachment indicate a high level of place attachment. Significant differences between north and south are found only for item $3 \mathrm{~d}$ with a higher share of positive answers in the north (north: 87 percent; south: 82 percent; $p=0.0321$ ).

Table 5: Summary of the dependent variable $((\mathrm{N}=942)$ : acceptance of a BGP development in respondents' vicinity (10km radius) in percent.

\begin{tabular}{|l|c|c|c|c|}
\hline Question wording & $\begin{array}{l}\text { Strongly } \\
\text { oppose }\end{array}$ & $\begin{array}{l}\text { Somewhat } \\
\text { oppose }\end{array}$ & $\begin{array}{l}\text { Somewhat } \\
\text { support }\end{array}$ & $\begin{array}{l}\text { Strongly } \\
\text { support }\end{array}$ \\
\hline $\begin{array}{l}\text { How strongly would you support or oppose } \\
\text { the construction of the following renewable } \\
\text { power plants and natural gas-fired plant } \\
\text { within a 10km radius of your place of } \\
\text { residence? }\end{array}$ & 18.68 & 36.94 & 36.94 & 7.43 \\
\hline
\end{tabular}

Note: ${ }^{*}$ As well as BGPs, respondents were requested to rate wind energy, solar energy, and a natural gas-fired plant.

Spatial data shows a high heterogeneity with regard to respondents' exposure to BGPs and maize cultivation. Structural differences between north and south are clearly apparent: the number of BGPs is slightly and the share of maize cultivation is clearly higher in the north (see Table 4).

\subsection{Multivariate Results}

For each thematic group of variables, an exploratory factor analysis has been conducted. The results are reported in Table 3. On the basis of the factor analysis, mean scores are calculated, which are then used in the further multivariate analysis. Items that did not load sufficiently on the calculated factor are integrated separately in the multivariate analysis. Table 6 reports models of logit regression analysis. Therefore, the ordinally scaled variable measuring acceptance of a BGP development in the vicinity of respondents has been recoded to a binary variable with " 1 " measuring support (corresponding to 44.4 percent of respondents). We

\footnotetext{
${ }^{3}$ For each variable, the share of positive answers and the significance level of the Mann-Whitney test is reported.
} 
decided to conduct a logistic regression analysis for reasons of content and simplicity: we only want to know if respondents would accept a new BGP in their vicinity or not and what are the influencing factors on acceptance. We have also estimated ordered logit models and, due to the violation of the parallel regression assumption (Long and Freese, 2006, pp. 197-200), generalized ordered models (Long and Freese, 2006, 220f) as well as ordinary least squares (OLS) models. All of them produced similar results.

To assess the explanatory power of the factors introduced, we will compare a basic model that includes sociodemographic variables only (Model 1) with models that also include one of the factors (Model $2-5 b$ ) and the full model (Model 6a and 6b). Following Gravelle and Lachapelle (2015), log-transformed distances are used for the covariate "distance to BGP." 
Table 6: Multivariate models (N=942).

\begin{tabular}{|c|c|c|c|c|c|c|c|c|}
\hline & Model 1 & Model 2 & Model 3 & Model 4 & Model 5a & Model 5b & Model 6a & Model 6b \\
\hline $\begin{array}{l}\text { Age } \\
\text { (centered) }\end{array}$ & $\begin{array}{l}-0.008 \\
(-1.50)\end{array}$ & $\begin{array}{l}0.004 \\
(0.62)\end{array}$ & $\begin{array}{c}0.0103^{+} \\
(1.79)\end{array}$ & $\begin{array}{l}-0.009^{+} \\
(-1.67)\end{array}$ & $\begin{array}{l}-0.008 \\
(-1.49)\end{array}$ & $\begin{array}{l}-0.008^{+} \\
(-1.65)\end{array}$ & $\begin{array}{l}0.010 \\
(1.39)\end{array}$ & $\begin{array}{l}0.009 \\
(1.27)\end{array}$ \\
\hline $\begin{array}{l}\text { Education } \\
\text { (years) }\end{array}$ & $\begin{array}{l}0.056^{* * *} \\
(2.89)\end{array}$ & $\begin{array}{l}0.057^{*} \\
(2.21)\end{array}$ & $\begin{array}{c}0.071^{* * * *} \\
(3.31)\end{array}$ & $\begin{array}{l}0.056^{* *} \\
(2.87)\end{array}$ & $\begin{array}{c}0.0540^{* *} \\
(2.80)\end{array}$ & $\begin{array}{c}0.0554^{* * *} \\
(2.86)\end{array}$ & $\begin{array}{l}0.063^{*} \\
(2.36)\end{array}$ & $\begin{array}{l}0.062^{*} \\
(2.33)\end{array}$ \\
\hline $\begin{array}{l}\text { Gender } \\
\text { (ref. female) }\end{array}$ & $\begin{array}{l}-0.417^{\text {** }} \\
(-3.05)\end{array}$ & $\begin{array}{c}-0.500^{* *} \\
(-2.78)\end{array}$ & $\begin{array}{l}-0.471^{* *} \\
(-3.12)\end{array}$ & $\begin{array}{c}-0.420^{* *} \\
(-3.02)\end{array}$ & $\begin{array}{c}-0.402^{* *} \\
(-2.92)\end{array}$ & $\begin{array}{c}-0.396^{* *} \\
(-2.87)\end{array}$ & $\begin{array}{c}-0.560^{* *} \\
(-2.96)\end{array}$ & $\begin{array}{c}-0.572^{* *} \\
(-3.02)\end{array}$ \\
\hline $\begin{array}{l}\text { Place of residence } \\
\text { (ref. rural) }\end{array}$ & $\begin{array}{l}-0.167 \\
(-1.21)\end{array}$ & $\begin{array}{l}0.050 \\
(0.27)\end{array}$ & $\begin{array}{l}-0.188 \\
(-1.22)\end{array}$ & $\begin{array}{l}-0.181 \\
(-1.29)\end{array}$ & $\begin{array}{l}-0.132 \\
(-0.92)\end{array}$ & $\begin{array}{l}-0.218 \\
(-1.53)\end{array}$ & $\begin{array}{l}-0.046 \\
(-0.24)\end{array}$ & $\begin{array}{l}-0.060 \\
(-0.31)\end{array}$ \\
\hline $\begin{array}{l}\text { Region } \\
\text { (ref. north) }\end{array}$ & $\begin{array}{l}-0.540^{* * * *} \\
(-3.99)\end{array}$ & $\begin{array}{l}-0.213 \\
(-1.20)\end{array}$ & $\begin{array}{c}-0.541^{* * * *} \\
(-3.63)\end{array}$ & $\begin{array}{l}-0.534^{* * *} \\
(-3.93)\end{array}$ & $\begin{array}{c}-0.486^{* * * *} \\
(-3.46)\end{array}$ & $\begin{array}{c}-0.455^{* *} \\
(-3.27)\end{array}$ & $\begin{array}{l}-0.137 \\
(-0.72)\end{array}$ & $\begin{array}{l}-0.151 \\
(-0.80)\end{array}$ \\
\hline $\begin{array}{l}\text { Attitudes to biomass } \\
\text { (index } 1-4 \text { ) }\end{array}$ & & $\begin{array}{l}3.500^{* * * *} \\
(14.46)\end{array}$ & & & & & $\begin{array}{l}3.224^{* * *} \\
(12.77)\end{array}$ & $\begin{array}{l}3.192^{* * *} \\
(12.72)\end{array}$ \\
\hline $\begin{array}{l}\text { Biomass costs } \\
\text { (scale } 1-4)\end{array}$ & & $\begin{array}{l}0.202 \\
(1.50)\end{array}$ & & & & & $\begin{array}{l}0.268^{+} \\
(1.92)\end{array}$ & $\begin{array}{l}0.280^{*} \\
(2.01)\end{array}$ \\
\hline $\begin{array}{l}\text { Attitudes to maize } \\
\text { (index } 1 \text { - 4) }\end{array}$ & & & $\begin{array}{l}1.565^{* * *} \\
(11.72)\end{array}$ & & & & $\begin{array}{c}0.907^{* * * *} \\
(5.43)\end{array}$ & $\begin{array}{c}0.913^{* * *} \\
(5.46)\end{array}$ \\
\hline $\begin{array}{l}\text { Place attachment } \\
\text { (index } 1-4 \text { ) }\end{array}$ & & & & $\begin{array}{l}0.154 \\
(1.17)\end{array}$ & & & $\begin{array}{l}0.417^{*} \\
(2.33)\end{array}$ & $\begin{array}{l}0.435^{*} \\
(2.41)\end{array}$ \\
\hline $\begin{array}{l}\text { Landscape change } \\
\text { (scale } 1-4)\end{array}$ & & & & $\begin{array}{c}-0.0914 \\
(-0.84)\end{array}$ & & & $\begin{array}{l}-0.204 \\
(-1.39)\end{array}$ & $\begin{array}{l}-0.201 \\
(-1.37)\end{array}$ \\
\hline Maize intensity & & & & & $\begin{array}{l}-1.210 \\
(-1.42)\end{array}$ & $\begin{array}{l}-2.102^{* *} \\
(-2.78)\end{array}$ & $\begin{array}{l}-2.386^{*} \\
(-2.08)\end{array}$ & $\begin{array}{l}-2.259^{*} \\
(-2.29)\end{array}$ \\
\hline
\end{tabular}


Table 6 (continued): Multivariate models ( $\mathrm{N}=942)$.

\begin{tabular}{|l|c|c|c|c|c|c|c|c|}
\hline & Model 1 & Model 2 & Model 3 & Model 4 & Model 5a & Model 5b & Model 6a & Model 6b \\
\hline Density of BGP & & & & & -0.008 & & 0.013 \\
$(-0.57)$ & & & & $\begin{array}{c}-0.379^{* *} \\
(-2.60)\end{array}$ & \\
\hline $\begin{array}{l}\text { Distance to BGP } \\
(\log )\end{array}$ & & & & & & $-0.72)$ & -0.230 \\
\hline Intercept & & & & & $-1.18)$ \\
\hline Pseudo $R^{2}$ & -0.418 & $-9.600^{* * *}$ & $-3.976^{* * *}$ & -0.646 & -0.164 & 0.402 & $-11.63^{* * *}$ & $-11.25^{* * *}$ \\
$(-1.48)$ & $(-12.62)$ & $(-9.02)$ & $(-1.25)$ & $(-0.54)$ & $(1.06)$ & $(-10.79)$ & $(-10.21)$ \\
\hline
\end{tabular}

Note: Logistic regression for the dependent variable "acceptance of a BGP development in respondents' vicinity (10km radius)" ( $1=$ support; $0=$ oppose), $\mathrm{z}$-values in parentheses. ${ }^{+} \mathrm{p}<0.1 ;{ }^{*} \mathrm{p}<0.05 ;{ }^{* *} \mathrm{p}<0.01 ; * * * \mathrm{p}<0.001$. 
Model 1 - Basic Model. We find statistically significant effects for education and gender that are stable in all of the extended models. The higher the level of education, the higher the probability that respondents support the construction of a BGP in their vicinity. Female respondents more likely tend to oppose this. Furthermore, we find a significantly negative effect of the dummy variable "region," indicating whether respondents live in the northern (reference category) or southern survey region. Apart from in Model 3 and Models $6 \mathrm{a}$ and 6b, respondents from the north are more likely to oppose the construction of a new BGP. There is no effect of the place of residence, meaning that there is no difference in acceptance of a BGP between rural and urban populations. Age does not show a statistically significant effect in the basic model. Its effects in Models 3, 4, and 5b show mixed results (positive in Model 3, negative in Models 4 and 5b). As they are only weakly statistically significant, we do not take them into consideration. As indicated by the pseudo R-squared value, the explanatory power of the basic model is very low.

Model 2 -Attitudes to biomass. According to the results of the factor analysis (see Table 3), we include an index of attitude toward power generation from biomass and an additional variable "biomass costs." This model shows a high explanatory power with a pseudo R-squared of 0.380 . As expected, the attitudes index has a positive effect which is strongly statistically significant. Respondents who rate power generation from biomass positively are more likely to accept the construction of a BGP in their vicinity. Perceived costs of power generation from biomass show no effect.

Model 3 -Attitudes to maize. Attitudes toward maize cultivation show a statistically significant positive effect on acceptance as well. Respondents who evaluate maize cultivation positively are more likely to accept a BGP in their vicinity. However, the explanatory power of this model is considerably lower than in Model 2.

Model 4-Place attachment. According to the results of the factor analysis, we include an index of place attachment and an additional variable "landscape changes." Neither variable shows significant effects. This means that those who have a strong place attachment and those who do not want the landscape surrounding them to change show neither a higher nor a lower probability of accepting a new BGP in their vicinity compared to respondents who are less strongly attached to their place.

Model $5 a$ and $b$-Spatial data. Partly, taking spatial information into account yields statistically significant results. It is only in Model $5 \mathrm{~b}$ that the intensity of maize cultivation and the distance to the nearest BGP have a statistically significant negative effect on acceptance. This means 
that the higher the share of maize cultivation in total agricultural area in the vicinity of respondents, the lower the probability that respondents accept a BGP in their vicinity. Further, the smaller the distance to the closest existing BGP, the higher the probability that respondents accept a BGP in their vicinity. The number of BGPs in the $10 \mathrm{~km}$ radius of respondents' place of residence does not affect the probability of accepting a new BGP in their vicinity. With pseudo R-squared $=0.033$ and 0.038 , explanatory power is low.

Model $6 a$ and $6 b-$ Full model. With pseudo R-squareds of 0.410 and 0.411 , the full models have the highest explanatory power. The statistically significant positive effect of attitudes toward power generation from biomass and maize cultivation remains when we control for other variables. The same applies to the effect of the spatial variable "maize intensity." The variable "density of BGP" does not show any effect while that of "distance to BGP" disappears in the full model. In contrast to the results of Models 2 and 4, the place attachment variables and the variable "biomass costs" exert a significant positive effect in the full model. These effects seem to be somewhat spurious results. Further inspection showed that the effect of place attachment is linked to the existence of the covariate "attitudes to maize" in the model. We found no interaction effect of attitudes toward maize cultivation and place attachment. ${ }^{4}$ The effect of "biomass costs" could not be localized. One aspect should be noted with regard to sociodemograhics: the variable "region" has a statistically significant effect in Models 1, 3, 4, and $5 \mathrm{a}$ and $\mathrm{b}$ but not in Models 2, 6a, and 6b. It seems that its effect is ruled out when the variable "attitudes to biomass" is included in the model. We assume that this performance of the variable "region" is caused by considerable and statistically significant distributional differences in the attitudinal variables, mentioned in Section 4.1 above. Power generation from biomass is evaluated more positively in the south.

An analysis of influential cases has been performed and nine influential observations have been identified. Model estimations with and without these observations yield similar results. However, there are some minor deviations. "Distance to BGP" is not only significant in Model $5 \mathrm{~b}$ but weakly significant in Model 6b, too. "Biomass costs" is also weakly significant in Model 2 (see Table A1 in the Appendix). The negative coefficient of "landscape change" is statistically

\footnotetext{
${ }^{4}$ Results for Model 6a:

- interaction term "attitudes to maize *place attachment": beta=-0.351; z-value=-1.28; p-value=0.20

- interaction term "attitudes to maize *landscape changes": beta=-0.061; z-value=-1.27; p-value=0.21 Results for Model 6b:

- interaction term "attitudes to maize *place attachment": beta $=-0.343 ; \mathrm{z}$-value $=-1.25 ; \mathrm{p}$-value $=0.21$

- interaction term "attitudes to maize *landscape changes": beta=-0.05; $\mathrm{z}$-value $=-1.24$; $\mathrm{p}$-value $=0.22$
} 
weakly significant in Models 6a and b. Respondents who oppose any changes to the surrounding landscape are also more likely to oppose the construction of a BGP in their vicinity. As inspection of influential cases did not give us any reason to remove them from the dataset, we decided not to exclude them from the dataset but found the small differences worth mentioning.

\section{Discussion}

As presented in Table 7, we are able to confirm our expected effects of attitudes; they show a strong positive effect on acceptance. Furthermore, attitudes regarding BGP add by far the most to explanatory power. Place attachment did not show significant effects in the separate model but did in the full model. This seems to be a misleading result: we cannot conclude that there is an effect of place attachment on the acceptance of BGP. There is a weak negative correlation between attitudes toward maize cultivation and place attachment (Spearman's Rho $=-0.133$ ) which seems to be the driver of this effect. However, we did not find any interaction effect between attitudes toward maize cultivation and place attachment.

To some extent, spatial variables do show a significant effect on the acceptance of BGP but their explanatory power is very small. The intensity of maize cultivation shows a stable negative effect. In contrast, "distance to BGP" exhibits a negative effect, meaning the closer a BGP, the higher the probability of acceptance. Density of BGPs does not show any effect.

Table 7: Overview on derived influencing factors and observed effects.

\begin{tabular}{|l|l|c|}
\hline \multicolumn{2}{|l|}{ Influencing factor } & $\begin{array}{l}\text { Observed effects on acceptance of a BGP } \\
\text { development in respondents' vicinity }\end{array}$ \\
\hline 1 & $\begin{array}{l}\text { Attitudes toward power generation } \\
\text { from biomass } \\
\text { Attitudes toward maize cultivation }\end{array}$ & positive \\
\hline 2 & Place attachment & positive \\
\hline 3 & $\begin{array}{l}\text { Spatial variables } \\
\text { Distance to BGP }\end{array}$ & no effect \\
& $\begin{array}{l}\text { Density of BGP } \\
\text { Intensity of maize cultivation }\end{array}$ & $\begin{array}{l}\text { (negative) } \\
\text { no effect } \\
\text { negative }\end{array}$ \\
\hline
\end{tabular}

The opposing effect of the spatial proximity to BGPs and the intensity of maize cultivation may represent the differences in spatial relevance of these variables. BGPs do not seem to be eyecatching and disturbing in the landscape but maize is cultivated on a large scale, grows up to three meters high and therefore seems to dominate the landscape in some regions. In line with this, descriptive analysis shows that attitudes toward maize cultivation are considerably more 
negative than those toward BGPs. Interestingly, the item "Maize cultivation has negative impacts on the natural scenery." is rated most positive compared to the other maize items. Nevertheless, the impact of land use on the acceptance of BGPs is relevant. These results emphasize the importance of diverse substrates for the production of biogas. The concentration on maize causes reduced acceptance.

We conducted our study in two different regions in Germany that are considerably different in terms of the development and structure of power generation from biomass. While the northern region is in the area of Germany with the highest installed capacity from biomass, in parts of the southern region we find the highest number of BGPs in Germany. Consequently, using the binary variable "region" to indicate which survey region respondents belong to, we have integrated spatial information of maize cultivation and the existing number of BGPs into our analysis on a highly aggregated level. However, solely on the basis of this spatially aggregated information, we could only assume that the characteristics of space might cause differences in acceptance. Other factors that differ between the two regions (such as aspects of procedural and distributive justice, for instance) might also help to explain this. For this reason, it is useful to integrate precise spatial data into the analysis of survey data, for example, in an environmental context.

There are some limitations of the study which should be discussed. First, our results are based on a hypothetical situation, respondents are not confronted with a specific BGP project in their vicinity. Acceptance is only conceptualized as an intention to behave but we do not observe real behavior. Hence, a hypothetical bias and social desirability might be a problem in the dataset and the acceptance of BGP might be overestimated. Nevertheless, as we assume these biases to be equally distributed in the sample, our analysis should provide meaningful results. Furthermore, as we did not restrict our data collection to local residents of a BGP project, we were able to collect data from different regions in Germany with different structural characteristics in terms of the number of BGPs, their size, and the use of the agricultural area. In addition, we were able to realize a greater number of interviews compared to case studies.

Second, there is an educational bias in our dataset, meaning that the higher educated are overrepresented and women are underrepresented. As women ${ }^{5}$ as well as the higher educated are more concerned about the environment (e.g., van Liere and Dunlap, 1980), they might be more interested in the survey topic and so took part. However, the share of respondents who

\footnotetext{
5 There is limited evidence for the effect of gender on environmental concern (see Brody et al., 2004; van Liere and Dunlap, 1980).
} 
accept a BGP in their vicinity is not much greater than in other representative surveys among the German population (see AEE, 2018b). Furthermore, the study aims to analyze the effect of subjective factors (attitudes and place attachment) and objective factors (spatial data). We would expect these effects to be independent of educational level.

Third, unfortunately, we cannot make a conclusive statement about the effect of place attachment as its effect seems to be linked to the maize attitude variables. We have only used four items to measure place attachment which might be not enough to capture all its facets. However, the correlation between maize attitudes and place attachment gives a further indication of the spatial relevance of maize cultivation.

Fourth, the availability of spatial information is limited as data on maize cultivation could be more up to date and more detailed. However, comparing data from 2010 and 2013 shows that the share of maize cultivation in total agricultural area is relatively stable. Therefore, more current data should not make a big difference. GIS would allow us to calculate proximity to maize fields and the exact total area of maize cultivation in the $10 \mathrm{~km}$ radius of respondents. To ensure privacy, we have to use aggregated data which offers an initial approach to the method.

\section{Conclusions and Policy Implications}

The main concern of this study was to further elaborate on the theoretical basis of research about acceptance of REs. We focus on BGPs which have been seldom considered to date and we integrate spatial information into our analysis on a relatively precise level. Other influencing factors examined are attitudes toward power generation from biomass and maize cultivation, and place attachment. Results show that attitudes have the strongest explanatory power but spatial variables, particularly maize intensity, contribute significantly, too. Place attachment does not show reliable effects.

From a methodical perspective, our study shows a high explanatory power of attitudes on acceptance of BGPs but spatial variables also contribute. The study therefore provides an incentive to further integrate spatial information into the analysis of survey data, not only in the field of BGPs and other REs. But as far as REs are concerned, it would be interesting to integrate further information about the RE plant (installed capacity, owner, and operating time, for instance) or visibility from respondents' (exact) place of residence into future research. Many studies that examine acceptance of REs take fairness aspects into account (Liebe et al., 2017; Soland et al., 2013; Wolsink, 2007). In the context of distributional justice, objective spatial information about existing power plants could provide new insights, for instance, through 
identifying thresholds of an unfair distribution of plants. Hence, our methodical approach may deliver important information for the specific political process concerning the implementation of RE technologies. On a more general level, information about the surrounding landscape or environmental quality could deliver meaningful results in environmentally oriented social science research and connected policy fields.

In summary, our study shows a comparably low level of acceptance for BGPs combined with rather critical attitudes toward energy from biomass and the related maize cultivation. These factors are behind the main effect on acceptance of BGPs in the multivariate analysis. Regarding spatial variables, the intensity of maize cultivation exerts a negative effect on acceptance. Consequently, from a policy point of view, in order to encourage acceptance of BGPs in the future, in addition to provide the population with information about energy generation from biogas and its impact on the environment, a prudent promotion of the biogas technology is needed that also takes landscape and environmental aspects into account as well as climate change. 


\section{Appendix}

Table A1: Multivariate models without influential observations (N=933).

\begin{tabular}{|c|c|c|c|c|c|c|c|c|}
\hline & Model 1 & Model 2 & Model 3 & Model 4 & Model 5a & Model 5b & Model 6a & Model 6b \\
\hline $\begin{array}{l}\text { Age } \\
\text { (centered) }\end{array}$ & $\begin{array}{l}-0.008 \\
(-1.60)\end{array}$ & $\begin{array}{l}0.004 \\
(0.55)\end{array}$ & $\begin{array}{l}0.011^{+} \\
(1.79)\end{array}$ & $\begin{array}{l}-0.009^{+} \\
(-1.81)\end{array}$ & $\begin{array}{l}-0.008 \\
(-1.59)\end{array}$ & $\begin{array}{l}-0.009^{+} \\
(-1.79)\end{array}$ & $\begin{array}{l}0.010 \\
(1.32)\end{array}$ & $\begin{array}{l}0.009 \\
(1.12)\end{array}$ \\
\hline $\begin{array}{l}\text { Education } \\
\text { (years) }\end{array}$ & $\begin{array}{l}0.061^{* *} \\
(3.12)\end{array}$ & $\begin{array}{l}0.073^{* *} \\
(2.69)\end{array}$ & $\begin{array}{c}0.081^{* * * *} \\
(3.71)\end{array}$ & $\begin{array}{l}0.061^{* *} \\
(3.11)\end{array}$ & $\begin{array}{l}0.059^{* *} \\
(3.04)\end{array}$ & $\begin{array}{l}0.061^{\text {*** }} \\
(3.10)\end{array}$ & $\begin{array}{l}0.083^{\text {** }} \\
(2.92)\end{array}$ & $\begin{array}{l}0.081^{* *} \\
(2.87)\end{array}$ \\
\hline $\begin{array}{l}\text { Gender } \\
\text { (ref. female) }\end{array}$ & $\begin{array}{l}-0.441^{* *} \\
(-3.20)\end{array}$ & $\begin{array}{l}-0.591^{* *} \\
(-3.14)\end{array}$ & $\begin{array}{c}-0.519^{* * * *} \\
(-3.38)\end{array}$ & $\begin{array}{l}-0.448^{* *} \\
(-3.19)\end{array}$ & $\begin{array}{l}-0.425^{* *} \\
(-3.07)\end{array}$ & $\begin{array}{l}-0.422^{* *} \\
(-3.04)\end{array}$ & $\begin{array}{c}-0.693^{* * *} \\
(-3.44)\end{array}$ & $\begin{array}{c}-0.719^{* * *} \\
(-3.56)\end{array}$ \\
\hline $\begin{array}{l}\text { Place of residence } \\
\text { (ref. rural) }\end{array}$ & $\begin{array}{l}-0.156 \\
(-1.12)\end{array}$ & $\begin{array}{l}0.093 \\
(0.49)\end{array}$ & $\begin{array}{l}-0.173 \\
(-1.11)\end{array}$ & $\begin{array}{l}-0.173 \\
(-1.22)\end{array}$ & $\begin{array}{l}-0.129 \\
(-0.89)\end{array}$ & $\begin{array}{l}-0.213 \\
(-1.49)\end{array}$ & $\begin{array}{l}-0.059 \\
(-0.28)\end{array}$ & $\begin{array}{l}-0.065 \\
(-0.32)\end{array}$ \\
\hline $\begin{array}{l}\text { Region } \\
\text { (ref. north) }\end{array}$ & $\begin{array}{l}-0.554^{* * *} \\
(-4.07)\end{array}$ & $\begin{array}{l}-0.208 \\
(-1.13)\end{array}$ & $\begin{array}{l}-0.571^{* * *} \\
(-3.77)\end{array}$ & $\begin{array}{l}-0.547^{* * *} \\
(-4.00)\end{array}$ & $\begin{array}{l}-0.492^{* * *} \\
(-3.49)\end{array}$ & $\begin{array}{l}-0.468^{* * *} \\
(-3.34)\end{array}$ & $\begin{array}{l}-0.100 \\
(-0.50)\end{array}$ & $\begin{array}{l}-0.136 \\
(-0.68)\end{array}$ \\
\hline $\begin{array}{l}\text { Attitudes to biogas } \\
\text { (index } 1-4 \text { ) }\end{array}$ & & $\begin{array}{l}3.938^{* * *} \\
(14.53)\end{array}$ & & & & & $\begin{array}{l}3.727^{* * * *} \\
(12.98)\end{array}$ & $\begin{array}{l}3.667^{\text {**** }} \\
(12.92)\end{array}$ \\
\hline $\begin{array}{l}\text { Biomass costs } \\
\text { (scale } 1-4)\end{array}$ & & $\begin{array}{l}0.280^{*} \\
(1.98)\end{array}$ & & & & & $\begin{array}{l}0.365^{*} \\
(2.45)\end{array}$ & $\begin{array}{l}0.390^{* *} \\
(2.63)\end{array}$ \\
\hline $\begin{array}{l}\text { Attitudes to maize } \\
\text { (index } 1-4 \text { ) }\end{array}$ & & & $\begin{array}{l}1.663^{* * *} \\
(12.04)\end{array}$ & & & & $\begin{array}{l}1.081^{* * *} \\
(6.03)\end{array}$ & $\begin{array}{c}1.092^{* * *} \\
(6.06)\end{array}$ \\
\hline $\begin{array}{l}\text { Place attachment } \\
\text { (index } 1-4 \text { ) }\end{array}$ & & & & $\begin{array}{l}0.185 \\
(1.39)\end{array}$ & & & $\begin{array}{l}0.586^{* * *} \\
(3.06)\end{array}$ & $\begin{array}{l}0.618^{* *} \\
(3.19)\end{array}$ \\
\hline $\begin{array}{l}\text { Landscape change } \\
\text { (scale } 1-4)\end{array}$ & & & & $\begin{array}{l}-0.108 \\
(-0.99)\end{array}$ & & & $\begin{array}{l}-0.266^{+} \\
(-1.70)\end{array}$ & $\begin{array}{l}-0.259^{+} \\
(-1.67)\end{array}$ \\
\hline
\end{tabular}


Table A1 (continued): Multivariate models without influential observations (N=933).

\begin{tabular}{|c|c|c|c|c|c|c|c|c|}
\hline & Model 1 & Model 2 & Model 3 & Model 4 & Model 5a & Model 5b & Model 6a & Model 6b \\
\hline Maize intensity & & & & & $\begin{array}{l}-1.400 \\
(-1.62)\end{array}$ & $\begin{array}{c}-2.253^{* *} \\
(-2.95)\end{array}$ & $\begin{array}{c}-3.305^{* *} \\
(-2.70)\end{array}$ & $\begin{array}{c}-2.854^{* *} \\
(-2.73)\end{array}$ \\
\hline Density of BGP & & & & & $\begin{array}{c}-0.00410 \\
(-0.31)\end{array}$ & & $\begin{array}{l}0.0275 \\
(1.45)\end{array}$ & \\
\hline $\begin{array}{l}\text { Distance to BGP } \\
(\log )\end{array}$ & & & & & & $\begin{array}{c}-0.434^{* *} \\
(-2.92)\end{array}$ & & $\begin{array}{l}-0.378^{+} \\
(-1.83)\end{array}$ \\
\hline Intercept & $\begin{array}{l}-0.473^{+} \\
(-1.67)\end{array}$ & $\begin{array}{l}-11.06^{* * *} \\
(-12.97)\end{array}$ & $\begin{array}{c}-4.298^{* * *} \\
(-9.45)\end{array}$ & $\begin{array}{l}-0.755 \\
(-1.44)\end{array}$ & $\begin{array}{l}-0.222 \\
(-0.72)\end{array}$ & $\begin{array}{l}0.439 \\
(1.15)\end{array}$ & $\begin{array}{c}-14.08^{* * *} \\
(-11.52)\end{array}$ & $\begin{array}{c}-13.43^{* * * *} \\
(-10.88)\end{array}$ \\
\hline Pseudo $R^{2}$ & 0.032 & 0.421 & 0.179 & 0.033 & 0.036 & 0.042 & 0.463 & 0.464 \\
\hline
\end{tabular}

Note: Logistic regression for the dependent variable "acceptance of a BGP development in respondents' vicinity (10km radius)" (1= support; $0=$ oppose), z-values in parentheses. ${ }^{+} \mathrm{p}<0.1 ; * \mathrm{p}<0.05 ; * * \mathrm{p}<0.01 ; * * * \mathrm{p}<0.001$ 


\section{References}

3N [Competence Center Lower Saxony Network Renewable Ressources - Kompetenzzentrum Niedersachsen Netzwerk Nachwachsende Rohstoffe e. V.], 2014. Biogas in Niedersachsen: Inventur 2014.

AAPOR [American Association for Public Opinion Research], 2016. Standard Definitions: Final Dispositions of Case Codes and Outcome Rates for Surveys. https://www.aapor.org/AAPOR_Main/media/publications/StandardDefinitions20169theditionfinal.pdf. Accessed 28 March 2018.

AEE [Renewable Energies Agency - Agentur für Erneuerbare Energien], 2018a. GrafikDossier zur jährlichen Akzeptanzumfrage der Agentur für Erneuerbare Energien: 93 Prozent der Bevölkerung in Deutschland unterstützen den verstärkten Ausbau Erneuerbarer Energien. https://www.unendlich-vielenergie.de/media/image/28191.AEE_akzeptanzumfrage2018_Unterstuetzung_Ausbau.jpg. Accessed 10 February 2019.

AEE [Renewable Energies Agency - Agentur für Erneuerbare Energien], 2018b. GrafikDossier zur jährlichen Akzeptanzumfrage der Agentur für Erneuerbare Energien: Hohe Zustimmungsraten zu Erneuerbare-Energien-Anlagen in der Umgebung des eigenen Wohnorts. https://www.unendlich-vielenergie.de/media/image/28041.AEE_akzeptanzumfrage2018_Zustimmung_EE_in_Nachba rschaft_72dpi.jpg. Accessed 10 February 2019.

Ansolabehere, S., Konisky, D.M., 2009. Public Attitudes Toward Construction of New Power Plants. Public Opinion Quarterly 73, 566-577. 10.1093/poq/nfp041.

Baxter, J., Morzaria, R., Hirsch, R., 2013. A case-control study of support/opposition to wind turbines: Perceptions of health risk, economic benefits, and community conflict. Energy Policy 61, 931-943. 10.1016/j.enpol.2013.06.050.

Bell, D., Gray, T., Haggett, C., Swaffield, J., 2013. Re-visiting the 'social gap': Public opinion and relations of power in the local politics of wind energy. Environmental Politics 22, 115-135. 10.1080/09644016.2013.755793.

Bertsch, V., Hall, M., Weinhardt, C., Fichtner, W., 2016. Public acceptance and preferences related to renewable energy and grid expansion policy: Empirical insights for Germany. Energy 114, 465-477. 10.1016/j.energy.2016.08.022.

BKG [Federal Agency for Cartography and Geodecy - Bundesamt für Kartographie und Geodäsie], 2013. Verwaltungsgebiete $1: 250000$.

BMU [Federal Ministry for the Environment, Nature Conversation and Nuclear Safety Bundesministerium für Umwelt, Naturschutz, Bau und Reaktorsicherheit]; BfN [Federal Agency for Nature Conservation - Bundesamt für Naturschutz], 2016. Naturbewusstsein 2015: Bevölkerungsumfrage zu Natur und biologischer Vielfalt.

BMWi [Federal Ministry for Economic Affairs and Energy - Bundesministerium für Wirtschaft und Energie], 2018. Erneuerbare Energien in Zahlen: Nationale und internationale Entwicklungen im Jahr 2017.

Borchers, A.M., Duke, J.M., Parsons, G.R., 2007. Does willingness to pay for green energy differ by source? Energy Policy 35, 3327-3334. 10.1016/j.enpol.2006.12.009. 
Brody, S.D., Highfield, W., Alston, L., 2004. Does Location Matter? Environment and Behavior 36, 229-250. 10.1177/0013916503256900.

Brown, B.B., Perkins, D.D., 1992. Disruption in Place Attachment, in: Altman, I., Low, S.M. (Eds.), Place Attachment. Springer US, Boston, MA, pp. 279-304.

Carlisle, J.E., Solan, D., Kane, S.L., Joe, J., 2016. Utility-scale solar and public attitudes toward siting: A critical examination of proximity. Land Use Policy 58, 491-501. 10.1016/j.landusepol.2016.08.006.

Carrus, G., Scopelliti, M., Fornara, F., Bonnes, Mirilia, Bonaiuto, Marino, 2014. Place Attachment, Community Identification, and Pro-Environmental Engagement, in: Manzo, L.C., Devine-Wright, P. (Eds.), Place attachment. Advances in theory, methods and applications. Routledge, London, pp. 154-164.

Clarke, C.E., Bugden, D., Hart, P.S., Stedman, R.C., Jacquet, J.B., Evensen, D.T.N., Boudet, H.S., 2016. How geographic distance and political ideology interact to influence public perception of unconventional oil/natural gas development. Energy Policy 97, 301-309. 10.1016/j.enpol.2016.07.032.

DBFZ [German Research Center Biomass - Deutsches Biomasseforschungszentrum], 2015. Stromerzeugung aus Biomasse (Vorhaben IIa Biomasse): Zwischenbericht Mai 2015, Leipzig.

destatis [Federal Statistical Office of Germany - Statistisches Bundesamt], 2012. Landwirtschaftlich genutzte Fläche rückläufig, Erntemengen legen zu. Pressemitteilung $360 / 12$ vom 15.10.2012.

destatis [Federal Statistical Office of Germany - Statistisches Bundesamt], 2014. 55\% der Ackerfläche wird 2014 zum Anbau von Getreide genutzt. Pressemitteilung 267/14 vom 30.07.2014.

destatis [Federal Statistical Office of Germany - Statistisches Bundesamt], 2016. Weizen und Silomais dominieren mit 45\% den Anbau auf dem Ackerland. Pressemitteilung 269/16 vom 03.08.2016.

destatis [Federal Statistical Office of Germany - Statistisches Bundesamt], 2018. Zahlen \& Fakten. https://www.destatis.de/DE/ZahlenFakten/GesellschaftStaat/StaatGesellschaft.html. Accessed 10 July 2018.

Devine-Wright, P., 2005. Beyond NIMBYism: Towards an integrated framework for understanding public perceptions of wind energy. Wind Energy 8, 125-139.

10.1002/we. 124 .

Devine-Wright, P., 2009. Rethinking NIMBYism: The role of place attachment and place identity in explaining place-protective action. J. Community. Appl. Soc. Psychol. 19, 426441. 10.1002/casp.1004.

Devine-Wright, P., 2011. Place attachment and public acceptance of renewable energy: A tidal energy case study. Journal of Environmental Psychology 31, 336-343.

10.1016/j.jenvp.2011.07.001.

Devine-Wright, P., 2013. Explaining "NIMBY" Objections to a Power Line: The Role of Personal, Place Attachment and Project-Related Factors. Environment and Behavior 45, 761-781. 10.1177/0013916512440435. 
Devine-Wright, P., Howes, Y., 2010. Disruption to place attachment and the protection of restorative environments: A wind energy case study. Journal of Environmental Psychology 30, 271-280. 10.1016/j.jenvp.2010.01.008.

Diekmann, A., Meyer, R., 2010. Demokratischer Smog? Eine empirische Untersuchung zum Zusammenhang zwischen Sozialschicht und Umweltbelastungen. Köln Z Soziol 62, 437457. 10.1007/s11577-010-0108-z.

Downey, L., 2006. Using Geographic Information Systems to Reconceptualize Spatial Relationships and Ecological Context. American Journal of Sociology 112, 567-612. $10.1086 / 506418$.

Eagly, A.H., Chaiken, S., 1998. Attitude Structure and Function, in: Gilbert, D.T., Fiske, S.T., Lindzey, G. (Eds.), The handbook of social psychology, $4^{\text {th }}$ ed. Distributed exclusively by Oxford University Press, Boston, New York, pp. 269-322.

Ek, K., 2005. Public and private attitudes towards "green" electricity: The case of Swedish wind power. Energy Policy 33, 1677-1689. 10.1016/j.enpol.2004.02.005.

Firestone, J., Hoen, B., Rand, J., Elliott, D., Hübner, G., Pohl, J., 2017. Reconsidering barriers to wind power projects: Community engagement, developer transparency and place. Journal of Environmental Policy \& Planning 20, 370-386. 10.1080/1523908X.2017.1418656.

FNR [Agency for Renewable Ressources - Fachagentur Nachwachsende Rohstoffe], 2015. Maisanbau in Deutschland. http://energiepflanzen.fnr.de/energiepflanzen/mais/. Accessed 21 October 2016.

Goodchild, M.F., Anselin, L., Appelbaum, R.P., Harthorn, B.H., 2000. Toward Spatially Integrated Social Science. International Regional Science Review 23, 139-159. $10.1177 / 016001760002300201$.

Gravelle, T.B., Lachapelle, E., 2015. Politics, proximity and the pipeline: Mapping public attitudes toward Keystone XL. Energy Policy 83, 99-108. 10.1016/j.enpol.2015.04.004.

Herbes, C., Jirka, E., Braun, J.P., Pukall, K., 2014. Der gesellschaftliche Diskurs um den „Maisdeckel“" vor und nach der Novelle des Erneuerbare-Energien-Gesetzes (EEG) 2012 The Social Discourse on the "Maize Cap" before and after the 2012 Amendment of the German Renewable Energies Act (EEG). gaia. 10.14512/gaia.23.2.7.

Jacquet, J.B., 2012. Landowner attitudes toward natural gas and wind farm development in northern Pennsylvania. Energy Policy 50, 677-688. 10.1016/j.enpol.2012.08.011.

Johansson, M., Laike, T., 2007. Intention to respond to local wind turbines: The role of attitudes and visual perception. Wind Energy 10, 435-451. 10.1002/we.232.

Kortsch, T., Hildebrand, J., Schweizer-Ries, P., 2015. Acceptance of biomass plants - Results of a longitudinal study in the bioenergy-region Altmark. Renewable Energy 83, 690-697. 10.1016/j.renene.2015.04.059.

Ladenburg, J., 2008. Attitudes towards on-land and offshore wind power development in Denmark; choice of development strategy. Renewable Energy 33, 111-118. 10.1016/j.renene.2007.01.011.

Ladenburg, J., Möller, B., 2011. Attitude and acceptance of offshore wind farms-The influence of travel time and wind farm attributes. Renewable and Sustainable Energy Reviews 15, 4223-4235. 10.1016/j.rser.2011.07.130. 
Langer, K., Decker, T., Roosen, J., Menrad, K., 2018. Factors influencing citizens' acceptance and non-acceptance of wind energy in Germany. Journal of Cleaner Production 175, 133144. 10.1016/j.jclepro.2017.11.221.

LANUV [North Rhine Westfalia State Agency for Nature, Environment and Consumer Protection - Landesamt für Natur, Umwelt und Verbraucherschutz NRW], 2017. Energieatlas Nordrhein-Westfalen. http://www.energieatlas.nrw.de/site. Accessed 17.7.18.

Liebe, U., Bartczak, A., Meyerhoff, J., 2017. A turbine is not only a turbine: The role of social context and fairness characteristics for the local acceptance of wind power. Energy Policy 107, 300-308. 10.1016/j.enpol.2017.04.043.

Linhart, E., Dhungel, A.-K., 2013. Das Thema Vermaisung im öffentlichen Diskurs. Berichte über Landwirtschaft - Zeitschrift für Agrarpolitik und Landwirtschaft, Band 91, Heft 2, August 2013. 10.12767/buel.v91i2.22.

Logan, J.R., 2012. Making a Place for Space: Spatial Thinking in Social Science. Annual review of sociology 38. 10.1146/annurev-soc-071811-145531.

Long, J.S., Freese, J., 2006. Regression models for categorical dependent variables using Stata, $2^{\text {nd }}$ ed., XXXII, $527 \mathrm{~S}$.

LSN [Statistical Office of Lower Saxony - Landesamt für Statistik Niedersachsen], 2012. Tabellenprogramm zu Landwirtschaftszählung 2010 Erhebung über Landwirtschaftliche Produktionsmethode (ELPM).

LUBW [State Office for Environment, Measurements and Nature Conservation in BadenWuerttemberg - Landesanstalt für Umwelt, Messungen und Naturschutz BadenWürttemberg], 2016. Standorte von Biogasanlagen.

Lucke, D., 1995. Akzeptanz: Legitimität in der „Abstimmungsgesellschaft“. Leske + Budrich, Opladen.

Mahafza, Z.B., Stoutenborough, J.W., Vedlitz, A., 2017. The role of proximity in problem identification: Risk of water scarcity in Texas. Water Policy 19, 86-98. 10.2166/wp.2016.021.

Marg, S., Hermann, C., Hambauer, V., Becké, A.B., 2013. „Wenn man was für die Natur machen will, stellt man da keine Masten hin“: Bürgerproteste gegen Bauprojekte im Zuge der Energiewende, in: Marg, S., Geiges, L., Butzlaff, F., Walter, F. (Eds.), Die neue Macht der Bürger. Was motiviert die Protestbewegungen? BP-Gesellschaftsstudie, 1st ed. Rowohlt, Reinbek bei Hamburg, pp. 94-138.

Meyerhoff, J., 2013. Do turbines in the vicinity of respondents' residences influence choices among programmes for future wind power generation? Journal of Choice Modelling 7, 5871. 10.1016/j.jocm.2013.04.010.

ML Niedersachsen [Ministry of Food, Agriculture and Consumer Protection Niedersächsisches Ministerium für Ernährung, Landwirtschaft und Verbraucherschutz Lower Saxony - Referat für Raumordnung und Landesplanung], 2016. Energieatlas Niedersachsen.

Mueller, C.E., Keil, S.I., Bauer, C., 2017. Effects of spatial proximity to proposed highvoltage transmission lines: Evidence from a natural experiment in Lower Saxony. Energy Policy 111, 137-147. 10.1016/j.enpol.2017.09.023. 
Nelson, H.T., Swanson, B., Cain, N.L., 2017. Close and Connected: The Effects of Proximity and Social Ties on Citizen Opposition to Electricity Transmission Lines. Environment and Behavior 50, 567-596. 10.1177/0013916517708598.

[Netztransparenz.de], 2012. EEG Anlagenstammdaten. http://www.netztransparenz.de/de/Anlagenstammdaten.htm. Accessed 22 September 2014.

Perlaviciute, G., Steg, L., 2014. Contextual and psychological factors shaping evaluations and acceptability of energy alternatives: Integrated review and research agenda. Renewable and Sustainable Energy Reviews 35, 361-381. 10.1016/j.rser.2014.04.003.

Porter, J.R., Howell, F.M., 2012. Geographical Sociology. Springer Netherlands, Dordrecht.

Radics, R., Dasmohapatra, S., Kelley, S.S., 2015. Systematic Review of Bioenergy Perception Studies. BIORESOURCES 10, 8770-8794.

Schumacher, K., Schultmann, F., 2017. Local Acceptance of Biogas Plants: A Comparative Study in the Trinational Upper Rhine Region. Waste Biomass Valor 8, 2393-2412. 10.1007/s12649-016-9802-z.

Schweizer-Ries, P., 2008. Energy sustainable communities: Environmental psychological investigations. Energy Policy 36, 4126-4135. 10.1016/j.enpol.2008.06.021.

Soini, K., Pouta, E., Salmiovirta, M., Uusitalo, M., Kivinen, T., 2011. Local residents' perceptions of energy landscape: The case of transmission lines. Land Use Policy 28, 294305. 10.1016/j.landusepol.2010.06.009.

Soini, K., Vaarala, H., Pouta, E., 2012. Residents' sense of place and landscape perceptions at the rural-urban interface. Landscape and Urban Planning 104, 124-134. 10.1016/j.Landurbplan.2011.10.002.

Soland, M., Steimer, N., Walter, G., 2013. Local acceptance of existing biogas plants in Switzerland. Energy Policy 61, 802-810. 10.1016/j.enpol.2013.06.111.

StMWi [Bavarian Minitry of Econmic Affairs, Regional Development and Energy Bayerisches Staatsministerium für Wirtschaft, Landesentwicklung und Energie], 2017. Energieatlas Bayern. http://geoportal.bayern.de/energieatlas-karten/?wicket-crypt=5w4ej2DzxY. Accessed 11 February 2019.

Swofford, J., Slattery, M., 2010. Public attitudes of wind energy in Texas: Local communities in close proximity to wind farms and their effect on decision-making. Energy Policy 38, 2508-2519. 10.1016/j.enpol.2009.12.046.

van Liere, K.D., Dunlap, R.E., 1980. The Social Bases of Environmental Concern: A Review of Hypotheses, Explanations and Empirical Evidence. Public Opinion Quarterly 44, 181. $10.1086 / 268583$.

Venables, D., Pidgeon, N.F., Parkhill, K.A., Henwood, K.L., Simmons, P., 2012. Living with nuclear power: Sense of place, proximity, and risk perceptions in local host communities. Journal of Environmental Psychology 32, 371-383. 10.1016/j.jenvp.2012.06.003.

Vorkinn, M., Riese, H., 2001. Environmental Concern in a Local Context: The Significance of Place Attachment. Environment and Behavior 33, 249-263.

10.1177/00139160121972972.

Warren, C.R., Lumsden, C., O’Dowd, S., Birnie, R.V., 2005. 'Green On Green': Public perceptions of wind power in Scotland and Ireland. Journal of Environmental Planning and Management 48, 853-875. 10.1080/09640560500294376. 
Wolsink, M., 2007. Wind power implementation: The nature of public attitudes: Equity and fairness instead of 'backyard motives'. Renewable and Sustainable Energy Reviews 11, 1188-1207. 10.1016/j.rser.2005.10.005.

Wüstenhagen, R., Wolsink, M., Bürer, M.J., 2007. Social acceptance of renewable energy innovation: An introduction to the concept. Energy Policy 35, 2683-2691.

10.1016/j.enpol.2006.12.001. 


\title{
V. Factorial survey experiments and direct measurements of fairness perceptions in energy justice research
}

Ulf Liebe and Geesche M. Dobers

Eingereicht bei Energy Research \& Social Science, im Review-Prozess

\begin{abstract}
Energy justice is an increasingly popular concept and comprises several justice dimensions including distributive and procedural justice related to energy production and consumption. In this paper, we demonstrate the usefulness of factorial survey experiments - a method employed in sociological justice research - for the field of energy justice. In a factorial survey, respondents evaluate one or more situations described by several attributes which vary in their levels. The experimental setup of factorial surveys is one of its advantages over simple survey items, as based on it, the relative importance of each attribute for justice evaluations can be determined. We employed the method in a study on the perceived fairness of renewable energy expansion projects in Germany, and considered aspects of procedural and distributive justice. We show that the effects of these justice dimensions can be separated and the heterogeneity in justice evaluations can be explained. Compared to previous studies applying factorial survey experiments to explain the acceptance of renewable energy projects, we employed the method to measure directly justice concerns and asked respondents to evaluate the vignettes in terms of perceived justice or fairness This is important because acceptance and justice are different phenomena.
\end{abstract}

Keywords: causal effects, energy justice, factorial surveys, renewable energy, vignette study 


\section{Introduction}

While much research on energy production and consumption is concerned with the concept of energy justice (Fuller and McCauley, 2016; Jenkins et al., 2016; Sovacool et al., 2016), there is little empirical quantitative research that directly measures citizens' justice concerns. For example, in research on the acceptance of energy infrastructure most researchers frame their work in the context of justice but empirically measure acceptance (Langer et al., 2017; Lienhoop, 2018; Walker et al., 2016; Walker and Baxter, 2017). A direct measurement of justice perceptions is important because social inequalities related to energy production and consumption do not necessarily imply injustice: inequality and perceived injustice regarding the exposure to environmental goods and bads are two different phenomena. On the one hand, the environmental and energy justice movement typically strive for an equal distribution of environmental harms and goods across social groups in society. On the other hand, research on social justice suggests that there are many different theories and principle of justice, and the question emerges which principle is supported by whom and how this depends on the social context (Liu, 2001; Miller, 1999, 1992; Sandel, 2010). For example, not all income groups might perceive an equal burden of rising energy costs as equally fair; also, citizens in different countries might evaluate an equal share of the costs of climate change mitigation across countries differently. The same can be true for aspects of procedural justice. It is, therefore, an important aspect of empirical justice research in sociology and other social sciences that inequality might not always be perceived as unjust and likewise equality might not always be perceived as just/fair ${ }^{1}$ and, hence, a direct measurement of justice perceptions is crucial (Liebig et al. 2015).

The literature on energy justice and related fields suggests that many aspects are relevant for fairness judgements (Baxter, 2017; Jenkins et al., 2016; Sovacool et al., 2016). In line with research on environmental justice (Schlosberg, 2007), these aspects often refer to distributive justice, participatory justice, and recognition (Fuller and McCauley, 2016; Jenkins et al., 2016). Yet, it is empirically challenging to disentangle the effects of these aspects. For example, it is difficult to clarify whether distributive justice is more relevant than participatory justice, or vice versa, for the perceived fairness and local acceptance of renewable energy projects. Factorial survey experiments can help to overcome many of these challenges.

\footnotetext{
${ }^{1}$ The term just / fair and justice / fairness are used synonymously.
} 
In a factorial survey experiment, also called a vignette experiment, respondents evaluate a situation (i.e. vignette) which is described by experimentally manipulated attributes (i.e. actors) which vary in their levels (Auspurg and Hinz, 2015). The respondents are then asked to evaluate these situations according to criteria such as support, agreement, or perceived fairness. Given that typically more than one attribute is manipulated, factorial survey experiments belong to socalled multifactorial methods which allow for the identification of causal effects due to the experimental setup (Auspurg and Hinz, 2015; Liebig et al., 2015). The method was introduced in Sociology by Rossi and Lazarsfeld in the 1950s (Rossi, 1979). Since the 1970s, factorial survey experiment has become an important method for the study of many phenomena including social norms and justice concerns (Auspurg and Hinz, 2015; Jasso and Opp, 1997; Jasso and Rossi, 1977; Liebig et al., 2015; Wallander, 2009). Since the method employs multiple factors and respondents have to make trade-offs, it also lowers socially desirable response behavior (Auspurg et al., 2015).

In this work, we aim to demonstrate the usefulness of the factorial survey method, for the field of energy justice. There are only two previous studies applying the method in the context of the social acceptance of wind energy projects (Liebe et al., 2017a; Walter and Gutscher, 2013). Yet, in these applications the explanandum is acceptance and not justice/fairness perceptions which are closer to the concept of energy justice. We argue that factorial surveys have advantages over other survey methods by directly measuring justice or fairness evaluations and offering a way to determine the relative importance of justice dimensions for the justice evaluation of energy related processes.

\section{A Factorial Survey Experiment on the Perceived Fairness of Energy Expansion}

\subsection{Experimental Design}

In designing and conducting a factorial survey experiment (see Auspurg and Hinz, 2015 for state-of-the art guidelines), researchers have to decide on the number of attributes (factors or characteristics) of a situation, and attribute levels have to be assigned. In our example on renewable energy projects, we described projects to construct a renewable energy site in the respondent's vicinity (10-km radius from their place of residence) and were interested how unfair or fair the respondents perceive these projects. We varied four attributes across vignettes. First, the project referred with (1) a wind farm (10 turbines), (2) a photovoltaic power station, or (3) a biogas plant to different types of renewable energy and, second, with (1) one, (2) three, or (3) five power plants to different magnitudes of exposure to power plants. Third, based on 
the literature on environmental justice, we included the attributes participatory justice, that is, citizens have (1) no say in the planning process, (2) partly say in the planning process, or (3) a say at every step in the planning process -, and, fourth, distributive justice - with the planned project respondents have (1) less power plants, (2) the same number, or (3) more power plants in their region than in other regions in Germany.

Combining all possible attribute combinations - $3 \times 3 \times 3 \times 3$-gives the so-called full factorial of 81 vignettes and hence 81 different project descriptions. We employed the full factorial and each respondent answered one vignette which was randomly chosen from the full factorial. Using randomization and the full factorial, we are able to experimentally isolate all main effects, two-way effects, and three-way effects between attributes. If a factorial survey study comprises more attributes or attribute levels, the full factorial is often too large to consider all vignettes. Thus, an experimental design is used to reduce the number of vignettes that respondents face, but at the same time, to maintain the possibility to separate the effects of single factors.

Researchers also have to choose a response scale for recording respondents' judgments (e.g., four-point, five-point, seven-point, or eleven-point response scales). While the literature rather suggests longer response scales (Auspurg and Hinz, 2015), in this study we opted for a fourpoint scale because we wanted to fully label each category of the scale using the words "fair" and "unfair". Figure 1 provides an example of a vignette as used in the study.

Figure 1: Example of a vignette used in the survey.

How fair or unfair do you find the construction of three wind farms (with the turbines) in your surroundings (radius of $10 \mathrm{~km}$ around your place of residence)? You, as a resident, have a say at every step in the planning process of the wind farms (choice of location, design, etc.). With the construction of these wind farms, your region will have more turbines than in most other regions in Germany.

If you live in a larger city, please think of the nearest surrounding.

I find the construction of these wind farms ...

\begin{tabular}{|c|c|c|c|}
\hline Very fair & Rather fair & Rather unfair & Very unfair \\
\hline 1 & 2 & 3 & 4 \\
\hline
\end{tabular}

Note: Attributes and attribute levels that vary across vignettes are underlined. 


\subsection{Data and Variables}

We embedded the factorial survey in an online survey on renewable energy expansion in Germany. The survey was conducted in September and October 2013 (see also Liebe and Dobers, 2019). Participants were members of an access panel who were actively recruited by phone (no opt-in panel) and represent the German population that uses the internet at least once a week. We used quota sampling representing the German population regarding gender and age as close as possible. After inspection of the data, out of 3,400 completed questionnaires, 3,199 usable interviews remained for analysing the factorial survey (due to missing values and implausible answers). The response rate (standard RR1 (AAPOR, 2016)) was 26 percent. Prior to the survey, six focus groups and two pretest surveys were conducted.

In our sample, women (45\% in the sample, $51 \%$ in the population) and those living in midsized cities (33\% in the sample, $42 \%$ in the population) are underrepresented and those with higher education, i.e. a university entrance diploma or higher, overrepresented $(61 \%$ in the sample, $31 \%$ in the population). The mean values for age (43 years, $\mathrm{SD}=14$ ) and household net income $(3,048$ Euro, $S D=1,519)$ are fairly close to the average values for the German population (destatis, 2015). While the sample is clearly not representative, it contains sufficient variance on sociodemographics in order to take heterogeneity in population characteristics into account. Since individuals in rural areas are more affected by renewable energy expansion compared to those in urban areas, our data also show considerable variance along the rural-urban continuum (31\% rural areas, 33\% mid-sized cities, 36\% large cities).

Table 1: Definition of renewable energy sources as used in the survey

\begin{tabular}{|c|c|c|}
\hline $\begin{array}{l}\text { Wind energy refers to } \\
\text { electricity generation with } \\
\text { single wind turbines and wind } \\
\text { farms onshore only. }\end{array}$ & $\begin{array}{l}\text { Solar energy refers } \\
\text { exclusively to the production } \\
\text { of electricity with photovoltaic } \\
\text { systems in the open landscape, } \\
\text { i.e., solar fields. }\end{array}$ & $\begin{array}{l}\text { Biomass refers to the } \\
\text { production of biogas and its } \\
\text { electricity and includes both } \\
\text { the biogas plant and the } \\
\text { cultivation of the required } \\
\text { biomass (such as corn). }\end{array}$ \\
\hline
\end{tabular}


In the survey we considered three renewable energy sources: wind energy, solar energy, and biomass. At the beginning of the survey, respondents were shown pictograms and definitions of these renewables (see Table 1). It was also clarified that the survey focused on renewables in the open landscape and did not consider energy production in urban areas, for example, through solar panels on roofs. ${ }^{2}$

\section{Results}

Table 2 shows the fairness evaluations regarding the construction of new power plants in respondents' vicinity across all vignettes and per renewable energy type. The figures indicate that there is remarkable variance on the fairness scale. However, for each energy type the majority of respondents perceives the construction of an additional plant as rather fair or very fair. The corresponding figures are $81 \%$ for solar energy, $67 \%$ for wind energy, and $56 \%$ for biomass. We can compare these figures with those from a question on the general acceptance of the construction of renewable power plants in respondents' vicinity. While there is a substantial positive correlation between the fairness and acceptance measure (all significant at $\mathrm{p}<0.001$ ), both are not perfectly correlated (Pearson correlations of $\mathrm{r}=0.529$ for wind energy, $\mathrm{r}=0.350$ for solar energy, and $\mathrm{r}=0.514$ for biomass). In other words: these measures discriminate to some extent, even if they correlate with each other.

Table 2: Fairness evaluations and acceptance levels per type of renewable energy plant.

\begin{tabular}{|c|c|c|c|c|c|}
\hline Plant type & $\begin{array}{c}\text { Very unfair } \\
\text { [Strongly } \\
\text { oppose] (1) }\end{array}$ & $\begin{array}{c}\text { Rather unfair } \\
\text { [Somewhat } \\
\text { oppose] (2) }\end{array}$ & $\begin{array}{l}\text { Rather fair } \\
\text { [Somewhat } \\
\text { support] (3) }\end{array}$ & $\begin{array}{c}\text { Very fair } \\
\text { [Strongly } \\
\text { support] (4) }\end{array}$ & Mean (SD) \\
\hline $\begin{array}{l}\text { Wind } \\
(n=1,051)\end{array}$ & $\begin{array}{c}7 \% \\
{[8 \%]}\end{array}$ & $\begin{array}{c}26 \% \\
{[19 \%]}\end{array}$ & $\begin{array}{c}54 \% \\
{[47 \%]}\end{array}$ & $\begin{array}{c}13 \% \\
{[26 \%]}\end{array}$ & $\begin{array}{c}2.73(0.78) \\
{[2.91(0.88)]}\end{array}$ \\
\hline $\begin{array}{l}\text { Solar } \\
(\mathrm{n}=1,075)\end{array}$ & $\begin{array}{c}3 \% \\
{[2 \%]} \\
\end{array}$ & $\begin{array}{l}16 \% \\
{[9 \%]} \\
\end{array}$ & $\begin{array}{c}60 \% \\
{[50 \%]} \\
\end{array}$ & $\begin{array}{c}21 \% \\
{[39 \%]}\end{array}$ & $\begin{array}{c}2.97(0.71) \\
{[3.26(0.70)]}\end{array}$ \\
\hline $\begin{array}{l}\text { Biomass } \\
(\mathrm{n}=1,073)\end{array}$ & $\begin{array}{c}13 \% \\
{[15 \%]}\end{array}$ & $\begin{array}{c}31 \% \\
{[34 \%]}\end{array}$ & $\begin{array}{c}48 \% \\
{[41 \%]}\end{array}$ & $\begin{array}{c}8 \% \\
{[10 \%]}\end{array}$ & $\begin{array}{c}2.51(0.81) \\
{[2.46(0.87)]}\end{array}$ \\
\hline
\end{tabular}

Note: First number in each cell refers to responses to the vignette questions and the second number in parentheses to the question "How strongly would you support or oppose the construction of the following renewable power plants within a 10-kilometer radius of your place of residence?"

In the following, we present plots for linear regression models on fairness evaluations per renewable energy type: first for models only including the vignette attributes (Figure 2) and

\footnotetext{
${ }^{2}$ In contrast to wind and solar energy the energy source is not unboundedly available in the case of biomass. Therefore, we asked respondents to consider the cultivation of raw material and the power plant when rating the renewable energy biomass. For the most part, biomass is used for electricity generation at the place of production.
} 
second for models including the vignette attributes and additional variables to explain heterogeneity in fairness evaluations (Figure 3 ). ${ }^{3}$ The results show that the number of renewable power plants does not have a significant effect on fairness evaluations regarding wind power and solar energy. There is only one negative and statistically significant effect for biomass indicating that the construction of five plants compared to one plant is associated with lower fairness perceptions. There are clear indications that procedural and distributive justice matter. With respect to all the renewable energies, having no say in the planning process is perceived as more unfair than having partly a say in the planning process. The corresponding effects are statistically significant and amount to 0.3 points on the four-point fairness scale. Yet, there is no statistically significant difference for having a say in all steps of the planning process compared to having partly a say in the planning process. It rather seems that respondents value the general possibility to participate in the planning process and not so much the extent of it. Regarding the distributive justice, respondents perceive more unfairness if the new power plants lead to overall more renewable power plants in their region as compared to other regions. The effects have a similar size like the ones for procedural justice and are all highly statistically significant. Only for solar energy, respondents perceive more unfairness also if they have fewer power plants in their region as compared to other regions. For wind energy and biomass, we find no statistically significant differences between less exposure and equal exposure to power plants across regions. ${ }^{4}$

\footnotetext{
${ }^{3}$ The full regression models underlying Figures 2 and 3 can be found in Table A1 in the Appendix. Table A2 in the Appendix contains for each renewable energy type a comparison of the results of a linear regression model, an ordered logit model and a binary logit model. In the latter, the dependent variable has value of 1 for the categories "very fair" and "rather fair", and 0 for the categories "rather unfair" and very unfair" on the four-point fairness scale. Since the results are similar across the different modelling variants, we present the results of linear regression models.

${ }^{4}$ We also checked interaction effects between vignette attributes. Taking all possible two-way and three-way interaction effects into account, we only found one statistically significant two-way interaction and three-way interaction in the model for wind energy. They show that the construction of five plants is evaluated as less unfair if respondents still have fewer renewable energy plants in the region compared to other regions. Yet, this interaction is evaluated less fair if residents have a say in the planning process compared to having partly a say.
} 
Figure 2: Regression models for fairness evaluations and vignette attributes.

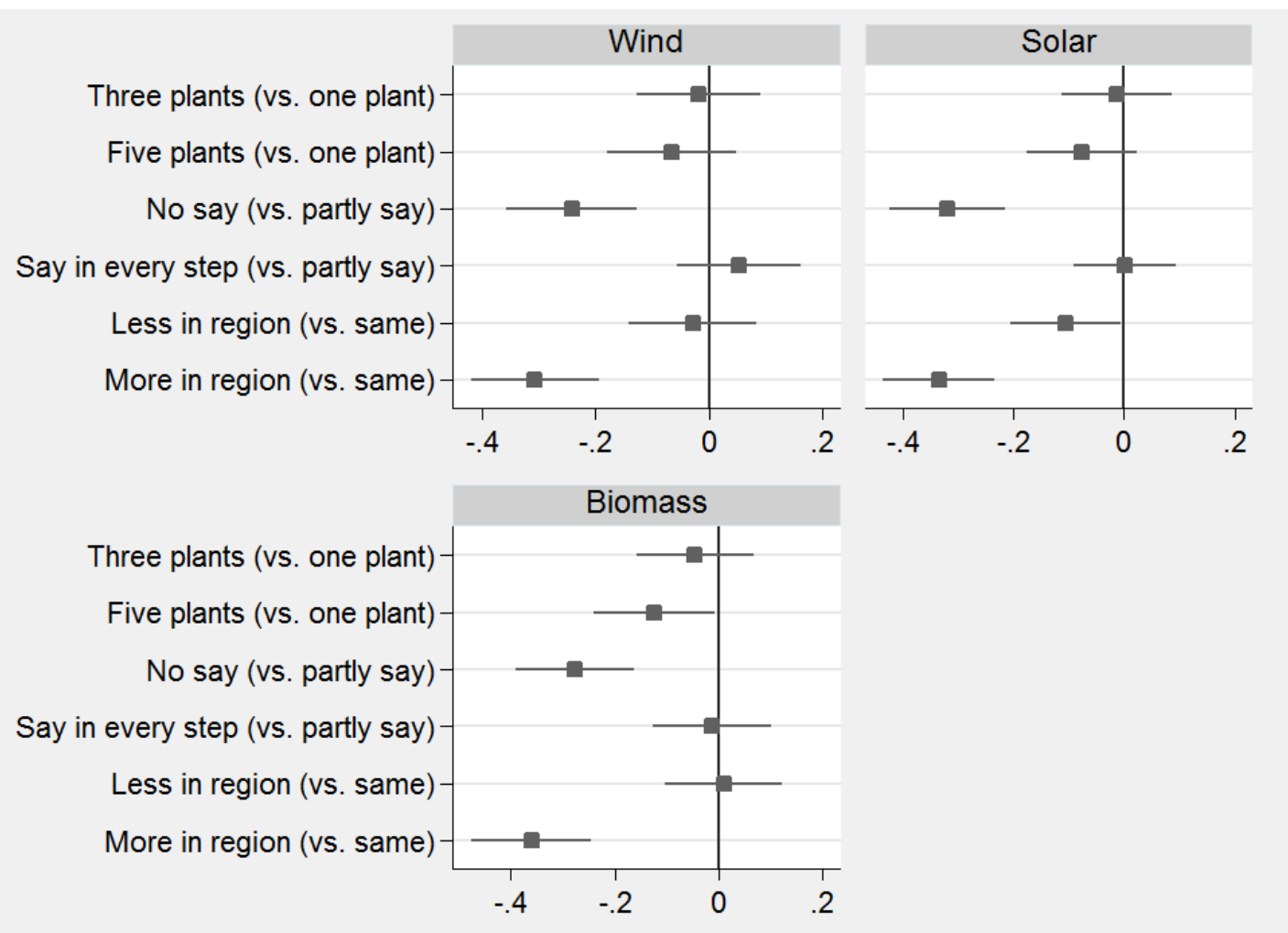

Note: unstandardized coefficients and $95 \%$ confidence intervals of linear regression models with the four-point fairness scale as dependent variable and the vignette attributes as independent variables. The model characteristics are as follows: for wind energy, $F(6,1044)=10.85$, Prob $>F=0.000, R^{2}=0.0596, n=1,051$; for solar energy, $F(6$, 1068) $=15.12$, Prob $>F=0.000, R^{2}=0.0844, n=1,075$; for biomass, $F(6,1066)=13.99$, Prob $>F=0.000, R^{2}=0.0746$, $\mathrm{n}=1,073$.

In Figure 3 are presented models that include additional variables to explain heterogeneity in fairness evaluations; the figure only depicts variables that had statistically significant effects on fairness evaluations (full models are presented in Table A2 in the Appendix). The main insights are that, as already shown above, the general acceptance of new renewable power plants in respondents' vicinity does have a positive effect on the perceived fairness; yet, causation can go in both directions. The effect sizes for a unit change range between 0.36 (solar energy) and 0.46 (wind energy and biomass) on the four-point fairness scale. Higher education is significantly associated with higher levels of perceived fairness at the 5\% level in the models on wind and solar energy.

Rural areas are more affected by renewable energy expansion than urban areas. However, we do not find remarkable differences in fairness evaluations between respondents living in medium-sized or large cities and those living in villages. Yet, there is one exception: compared to those living in villages: respondents residing in large cities perceive the construction of 
biomass power plants as rather fair. The effect amounts to 0.15 points on the four-point fairness scale. Place attachment ${ }^{5}$ does not significantly affect fairness concerns regarding solar and biomass but it has a negative and statistically significant effect on the perceived fairness of the construction of new wind energy plants. Of note, a 10-point increase on the place attachment scale, with a minimum value of 4 and a maximum value of 16 , is associated with a 0.25 decrease on the four-point fairness scale. This effect for wind energy might be due to the higher visibility of wind farms as compared with solar and biomass plants.

Figure 3: Regression models for fairness evaluations, vignette attributes, and respondents' characteristics.

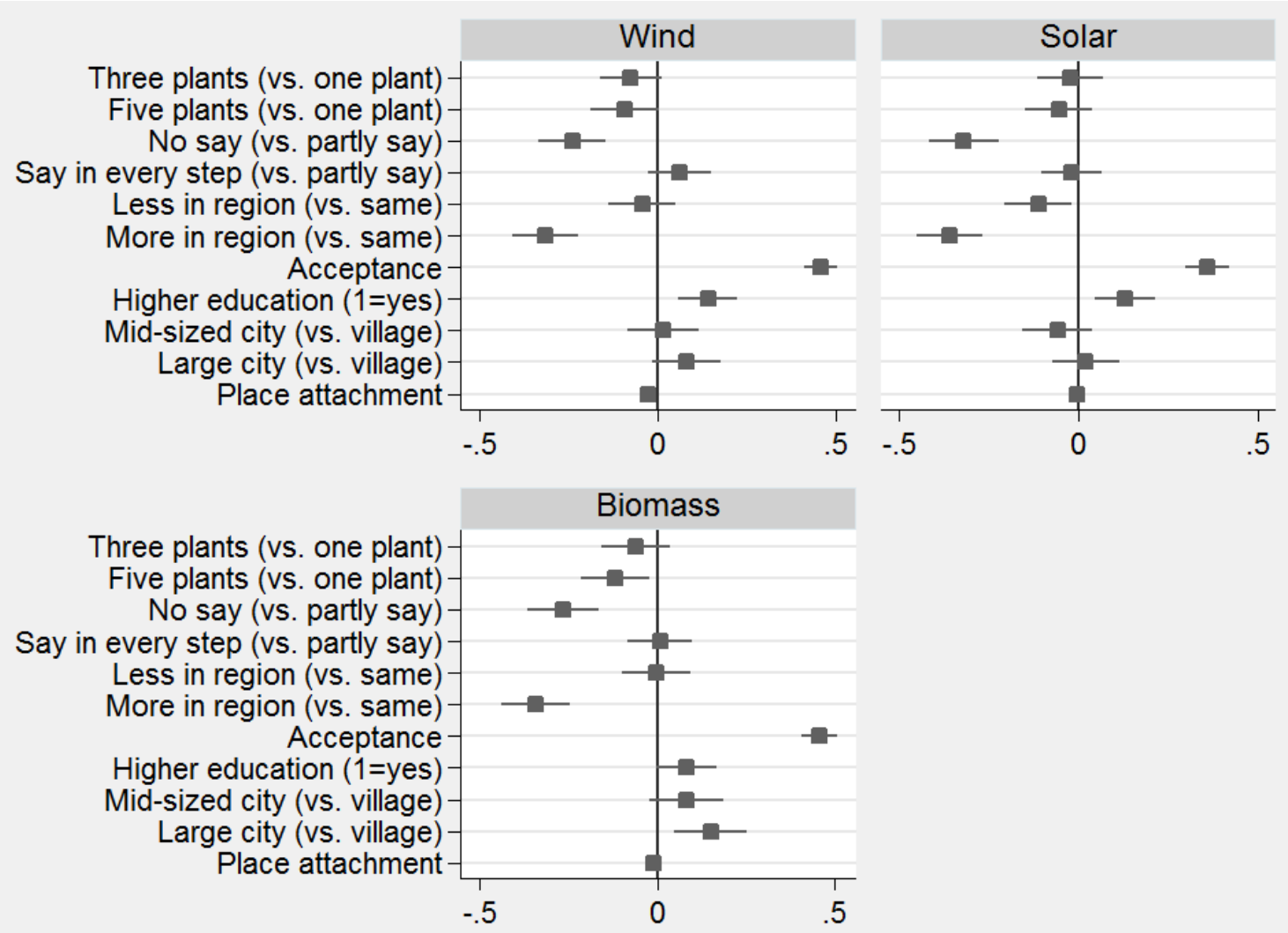

Note: unstandardized coefficients and $95 \%$ confidence intervals of linear regression models with the four-point fairness scale as dependent variable, and the vignette attributes and respondents' characteristics as independent variables. Not all respondent characteristics are shown; the underlying models also include gender, age, income, but these characteristics had statistically insignificant effects in all three models depicted. The model characteristic are as follows: for wind energy, $\mathrm{F}(14,1036)=44.12$, Prob $>\mathrm{F}=0.000, \mathrm{R}^{2}=0.3617, \mathrm{n}=1,051$; for solar energy, $\mathrm{F}(14$, $1060)=18.18$, Prob $>F=0.000, R^{2}=0.2226, n=1,075$; for biomass, $F(14,1058)=44.63$, Prob $>F=0.000, R^{2}=0.3504$, $\mathrm{n}=1,073$.

\footnotetext{
5 The survey also included questions on place attachment which we considered in the regression models on heterogeneity of fairness evaluations. The corresponding variable is an additive index of answers to the following four survey items, all answered on a four-point response scale ( $1=$ strongly disagree to $4=$ strongly agree): "I like to be in the landscape next to my place of residence.", "Often, I spend my free time in the landscape next to my place of residence.", "The landscape around my place of residence is a part of me.", "It is very important to me that the landscape around my place of residence does not change." Cronbach's alpha for the index is 0.7714 ; the index ranges between 4 and 16 with a mean of 13.085 and standard deviation of 2.233.
} 


\section{Discussion and Conclusions}

Energy justice is a multi-dimensional concept and it is challenging to disentangle the importance of each of the dimensions for justice/fairness evaluations. In this paper, we focused on distributive and procedural justice related to renewable energy expansion. Both justice dimensions are commonly discussed in the environmental justice and energy justice literature (e.g., Fuller and McCauley, 2016). We demonstrated how using factorial surveys can contribute to research on energy justice. By directly measuring justice/fairness evaluations and experimentally varying justice-related attributes across vignettes, it is possible to examine and disentangle the relevance of different justice dimensions for energy related projects. Our empirical study showed, for example, that the number of renewable energy plants is less important than aspects of procedural and distributive justice. Further, we found heterogeneity in justice concerns affected by education, place of residence, and place attachment as well as the type of renewable energy production.

More generally, factorial surveys have several advantages over standard survey items to measure justice concerns. Based on Liebig et al. (2015), Table 3 provides an overview of common problems in quantitative research on energy justice and refers to advantages of using factorial surveys to solve these problems. A standard survey item does not consider context information and this might prompt specific answers. In a factorial survey, respondents receive more context information and hence prompting should be less likely. Using standard survey items, it is difficult to determine the relative importance of justice dimensions. The experimental design underlying factorial surveys makes it possible to single out the relative importance of each dimension. Responses to standard survey items might lead to biased response behavior. For example, renewable energy expansion might be perceived as socially desirable and hence respondents might tend to agree with survey items in favor of renewable energy expansion. This cannot be completely ruled out in factorial surveys but should be less likely because respondents have to consider and make trade-offs between several attributes. Further, in research on energy justice, researchers explicitly or implicitly assume causal effects of justice dimensions on outcomes related to energy production and consumption. Yet, causal effects cannot be studied based on standard survey items and cross-sectional data. They can be examined, however, in factorial surveys and other population-based survey experiments (Mutz, 2011). 
Table 3: Advantages of Factorial Survey Experiments in Research on Energy Justice.

\begin{tabular}{|l|l|}
\hline $\begin{array}{l}\text { Problems of Empirical Research on } \\
\text { Energy Justice }\end{array}$ & $\begin{array}{l}\text { Advantages of Using Factorial Survey } \\
\text { Experiments }\end{array}$ \\
\hline $\begin{array}{l}\text { Single-item measures lack context- } \\
\text { information and might prompt certain } \\
\text { answers. }\end{array}$ & $\begin{array}{l}\text { Factorial survey experiments consider several } \\
\text { attributes, include more context information. } \\
\text { Respondents have to make trade-offs. This should } \\
\text { make prompting less likely. }\end{array}$ \\
\hline $\begin{array}{l}\text { Uncovering the relative importance of } \\
\text { factors relevant for justice evaluations }\end{array}$ & $\begin{array}{l}\text { Based on a multifactorial design and trade-offs } \\
\text { between attributes/factor, the effect/importance of } \\
\text { each factor for justice evaluations can be } \\
\text { determined. }\end{array}$ \\
\hline $\begin{array}{l}\text { Justice as a normative concept might } \\
\text { be prone to socially desirable response } \\
\text { behavior }\end{array}$ & $\begin{array}{l}\text { By presenting several factors at the same time, } \\
\text { socially desirable responses are less likely. }\end{array}$ \\
\hline Causal effects cannot be identified. & $\begin{array}{l}\text { By randomly varying vignette attributes causal } \\
\text { effects can be estimated. }\end{array}$ \\
\hline
\end{tabular}

Note: This table is based on Liebig et al. (2015).

We believe that factorial surveys can complemented the researcher's toolbox in the study of energy justice. The method should be combined with qualitative methods such as focus groups to develop the experimental design and to obtain an impression on how respondents perceive the vignettes and vignette attributes. As any other method, factorial surveys are not free of methodological issues such as the complexity of vignettes, the role of the response format (e.g. closed-ended versus open-ended question format), and order effects and fatigue, if multiple vignettes are presented per respondent (Auspurg and Jäckle, 2015; Sauer et al., 2011). These need to be considered when planning a factorial survey.

In this paper, we presented a rather simple application of factorial surveys. In another study on the local acceptance of wind power projects in Germany and Poland, Liebe et al. (2017a) also included attributes on the type of investor, the use of electricity (in the region versus for export), and the tax revenue resulting from the power plant. This means more justice dimensions and context factors can and possibly should be considered in factorial survey experiments (Baxter, 2017). But Liebe et al. (2017a) measured justice/fairness concerns not directly; they used an acceptance scale to measure respondents' evaluation of renewable energy projects. In future research on energy justice it should be considered that, even if highly correlated, acceptance is not the same as justice, and more generally, that environmental inequality does not equal environmental injustice. Besides energy infrastructure, factorial surveys can also be applied to justice concerns regarding energy poverty, involuntary resettlement, fossil fuel pollution, 
nuclear waste, climate change, etc. (Sovacool et al., 2016). Further, the method is also applicable in the global south (see Liebe et al., 2017b). The present paper paves the way for employing a direct measurement of justice concerns combined with factorial survey experiments to empirically disentangle the importance of different justice dimensions and thereby complement existing research on energy justice and subsequently (political) decision making. 


\section{Appendix}

Table A1: Full linear regressions models underlying Figure 2 and Figure 3 in the main text.

\begin{tabular}{|c|c|c|c|c|c|c|}
\hline & \multicolumn{3}{|c|}{ Figure 2} & \multicolumn{3}{|c|}{ Figure 3} \\
\hline & Wind & Solar & Biomass & Wind & Solar & Biomass \\
\hline $\begin{array}{l}\text { Three plants (vs. } \\
\text { one plant) }\end{array}$ & $\begin{array}{c}-0.0177 \\
(-0.32)\end{array}$ & $\begin{array}{c}-0.0127 \\
(-0.25)\end{array}$ & $\begin{array}{c}-0.0457 \\
(-0.80)\end{array}$ & $\begin{array}{c}-0.0746 \\
(-1.67)\end{array}$ & $\begin{array}{c}-0.0233 \\
(-0.51)\end{array}$ & $\begin{array}{l}-0.0601 \\
(-1.23)\end{array}$ \\
\hline $\begin{array}{l}\text { Five plants (vs. one } \\
\text { plant) }\end{array}$ & $\begin{array}{c}-0.0660 \\
(-1.15)\end{array}$ & $\begin{array}{c}-0.0753 \\
(-1.48)\end{array}$ & $\begin{array}{l}-0.123^{*} \\
(-2.08)\end{array}$ & $\begin{array}{l}-0.0915 \\
(-1.88)\end{array}$ & $\begin{array}{l}-0.0540 \\
(-1.13)\end{array}$ & $\begin{array}{l}-0.117^{*} \\
(-2.37)\end{array}$ \\
\hline $\begin{array}{l}\text { No say (vs. partly } \\
\text { say) }\end{array}$ & $\begin{array}{c}-0.242^{* * *} \\
(-4.14)\end{array}$ & $\begin{array}{l}-0.319^{* * * *} \\
(-6.00)\end{array}$ & $\begin{array}{c}-0.276^{* * *} \\
(-4.74)\end{array}$ & $\begin{array}{c}-0.239^{* * * *} \\
(-4.99)\end{array}$ & $\begin{array}{l}-0.320^{* * *} \\
(-6.46)\end{array}$ & $\begin{array}{c}-0.264^{* * * *} \\
(-5.21)\end{array}$ \\
\hline $\begin{array}{l}\text { Say in every step } \\
\text { (vs. partly say) }\end{array}$ & $\begin{array}{l}0.0526 \\
(0.95)\end{array}$ & $\begin{array}{c}0.000746 \\
(0.02)\end{array}$ & $\begin{array}{c}-0.0122 \\
(-0.21)\end{array}$ & $\begin{array}{c}0.0636 \\
(1.41)\end{array}$ & $\begin{array}{l}-0.0184 \\
(-0.43)\end{array}$ & $\begin{array}{c}0.00744 \\
(0.16)\end{array}$ \\
\hline $\begin{array}{l}\text { Less in region (vs. } \\
\text { same) }\end{array}$ & $\begin{array}{c}-0.0290 \\
(-0.51)\end{array}$ & $\begin{array}{l}-0.105^{*} \\
(-2.06)\end{array}$ & $\begin{array}{l}0.0101 \\
(0.18)\end{array}$ & $\begin{array}{l}-0.0422 \\
(-0.88)\end{array}$ & $\begin{array}{l}-0.113^{*} \\
(-2.36)\end{array}$ & $\begin{array}{c}-0.00116 \\
(-0.02)\end{array}$ \\
\hline $\begin{array}{l}\text { More in region (vs. } \\
\text { same) }\end{array}$ & $\begin{array}{c}-0.307^{* * * *} \\
(-5.35)\end{array}$ & $\begin{array}{l}-0.334^{* * * *} \\
(-6.50)\end{array}$ & $\begin{array}{c}-0.360^{* * *} \\
(-6.09)\end{array}$ & $\begin{array}{c}-0.316^{* * *} \\
(-6.71)\end{array}$ & $\begin{array}{c}-0.360^{* * *} \\
(-7.69)\end{array}$ & $\begin{array}{l}-0.341^{* * * *} \\
(-6.99)\end{array}$ \\
\hline $\begin{array}{l}\text { Acceptance of plant } \\
\text { in vicinity }\end{array}$ & & & & $\begin{array}{l}0.459^{* * *} \\
(19.16)\end{array}$ & $\begin{array}{l}0.359^{* * * *} \\
(11.40)\end{array}$ & $\begin{array}{l}0.457^{* * *} \\
(17.96)\end{array}$ \\
\hline Woman (vs. man) & & & & $\begin{array}{l}-0.0356 \\
(-0.89)\end{array}$ & $\begin{array}{c}-0.00455 \\
(-0.12)\end{array}$ & $\begin{array}{c}-0.00282 \\
(-0.07)\end{array}$ \\
\hline Age in years & & & & $\begin{array}{c}-0.000910 \\
(-0.60)\end{array}$ & $\begin{array}{c}-0.00266 \\
(-1.83)\end{array}$ & $\begin{array}{c}-0.00359^{*} \\
(-2.32)\end{array}$ \\
\hline $\begin{array}{l}\text { Higher education } \\
\text { (vs. less education) }\end{array}$ & & & & $\begin{array}{c}0.142^{* * * *} \\
(3.39)\end{array}$ & $\begin{array}{l}0.130^{* *} \\
(3.06)\end{array}$ & $\begin{array}{l}0.0823 \\
(1.86)\end{array}$ \\
\hline
\end{tabular}

Note: $\mathrm{t}$ statistics in parentheses; ${ }^{*} \mathrm{p}<0.05,{ }^{* *} \mathrm{p}<0.01,{ }^{* * *} \mathrm{p}<0.001$. 
Table A1 (continued): Full linear regressions models underlying Figure 2 and Figure 3 in the main text.

\begin{tabular}{|c|c|c|c|c|c|c|}
\hline & \multicolumn{3}{|c|}{ Figure 2} & \multicolumn{3}{|c|}{ Figure 3} \\
\hline & Wind & Solar & Biomass & Wind & Solar & Biomass \\
\hline Net income in Euro & & & & $\begin{array}{l}0.00000384 \\
\quad(0.18)\end{array}$ & $\begin{array}{l}0.0000278 \\
(1.34)\end{array}$ & $\begin{array}{l}0.00000583 \\
(0.26)\end{array}$ \\
\hline $\begin{array}{l}\text { Medium-sized city } \\
\text { (vs. small city) }\end{array}$ & & & & $\begin{array}{l}0.0179 \\
(0.35)\end{array}$ & $\begin{array}{l}-0.0583 \\
(-1.19)\end{array}$ & $\begin{array}{c}0.0812 \\
(1.53)\end{array}$ \\
\hline $\begin{array}{l}\text { Large city (vs. } \\
\text { small city) }\end{array}$ & & & & $\begin{array}{l}0.0823 \\
(1.66)\end{array}$ & $\begin{array}{l}0.0203 \\
(0.43)\end{array}$ & $\begin{array}{l}0.151^{* *} \\
(2.92)\end{array}$ \\
\hline Place attachment & & & & $\begin{array}{c}-0.0251^{* *} \\
(-2.75)\end{array}$ & $\begin{array}{c}-0.00297 \\
(-0.31)\end{array}$ & $\begin{array}{c}-0.00954 \\
(-0.90)\end{array}$ \\
\hline Constant & $\begin{array}{l}2.931^{* * * *} \\
(49.33)\end{array}$ & $\begin{array}{l}3.256^{* * *} \\
(58.16)\end{array}$ & $\begin{array}{l}2.779^{* * *} \\
(43.85)\end{array}$ & $\begin{array}{l}1.879^{* * *} \\
(11.03)\end{array}$ & $\begin{array}{l}2.132^{* * * *} \\
(11.92)\end{array}$ & $\begin{array}{l}1.777^{* * *} \\
(9.76)\end{array}$ \\
\hline $\mathrm{R}^{2}$ & 0.060 & 0.084 & 0.075 & 0.362 & 0.223 & 0.350 \\
\hline $\mathrm{N}$ & 1051 & 1075 & 1073 & 1051 & 1075 & 1073 \\
\hline
\end{tabular}

Note: $t$ statistics in parentheses; ${ }^{*} p<0.05,{ }^{* * *} p<0.01,{ }^{* * *} p<0.001$. 
Table A2: Comparison of linear regression, ordered logit, and binary logit models.

\begin{tabular}{|l|ccc|ccc|cc|}
\hline & Linear & $\begin{array}{c}\text { Wind } \\
\text { Ordered }\end{array}$ & Binary & Linear & $\begin{array}{c}\text { Solar } \\
\text { Ordered }\end{array}$ & Binary & Linear & $\begin{array}{c}\text { Biomass } \\
\text { Ordered }\end{array}$ \\
Binary
\end{tabular}

Note: $t$ statistics in parentheses; ${ }^{*} \mathrm{p}<0.05,{ }^{* * *} \mathrm{p}<0.01,{ }^{* * * *} \mathrm{p}<0.001$. 


\section{References}

AAPOR [American Association for Public Opinion Research], 2016. Standard Definitions: Final Dispositions of Case Codes and Outcome Rates for Surveys. https://www.aapor.org/AAPOR_Main/media/publications/StandardDefinitions20169theditionfinal.pdf. Accessed 28 March 2018.

Auspurg, K., Hinz, T., 2015. Factorial survey experiments. Quantitative applications in the social sciences (175) Sage, Los Angeles.

Auspurg, K., Hinz, T., Sauer, C., Liebig, S., 2015. The Factorial Survey as Method for Measuring Sensitive Issues. In: Engel, U., Jann, B., Lynn, P., Scherpenzeel, A.C., Sturgis, P. (Eds.), Improving survey methods. Lessons from recent research. Routledge, New York, pp. 137-152.

Auspurg, K., Jäckle, A., 2015. First Equals Most Important? Order Effects in Vignette-Based Measurement. Sociological Methods \& Research 46, 490-539. $10.1177 / 0049124115591016$.

Baxter, J., 2017. Energy justice: Participation promotes acceptance. Nature Energy 2, 17128. 10.1038/nenergy.2017.128.

destatis [Federal Statistical Office of Germany], 2015. Statistisches Jahrbuch Deutschland und Internationales. Wiesbaden.

Fuller, S., McCauley, D., 2016. Framing energy justice: Perspectives from activism and advocacy. Energy Research \& Social Science 11, 1-8. 10.1016/j.erss.2015.08.004.

Jasso, G., Opp, K.-D., 1997. Probing the character of norms: A factorial survey analysis of the norms of political action. American Sociological Review 62, 947-964.

Jasso, G., Rossi, P.H., 1977. Distributive Justice and Earned Income. American Sociological Review 42, 639. 10.2307/2094561.

Jenkins, K., McCauley, D., Heffron, R., Stephan, H., Rehner, R., 2016. Energy justice: A conceptual review. Energy Research \& Social Science 11, 174-182. 10.1016/j.erss.2015.10.004.

Langer, K., Decker, T., Menrad, K., 2017. Public participation in wind energy projects located in Germany: Which form of participation is the key to acceptance? Renewable Energy 112, 63-73. 10.1016/j.renene.2017.05.021.

Liebe, U., Bartczak, A., Meyerhoff, J., 2017a. A turbine is not only a turbine: The role of social context and fairness characteristics for the local acceptance of wind power. Energy Policy 107, 300-308. 10.1016/j.enpol.2017.04.043.

Liebe, U., Dobers, G.M., 2019. Decomposing public support for energy policy: What drives acceptance of and intentions to protest against renewable energy expansion in Germany? Energy Research \& Social Science 47, 247-260. 10.1016/j.erss.2018.09.004.

Liebe, U., Moumouni, I.M., Bigler, C., Ingabire, C., Bieri, S., 2017b. Using Factorial Survey Experiments to Measure Attitudes, Social Norms, and Fairness Concerns in Developing Countries. Sociological Methods \& Research 43, 1-32. 10.1177/0049124117729707.

Liebig, S., Sauer, C., Friedhoff, S., 2015. Using Factorial Surveys to Study Justice Perceptions: Five Methodological Problems of Attitudinal Justice Research. Social Justice Research 28, 415-434. 10.1007/s11211-015-0256-4. 
Lienhoop, N., 2018. Acceptance of wind energy and the role of financial and procedural participation: An investigation with focus groups and choice experiments. Energy Policy 118, 97-105. 10.1016/j.enpol.2018.03.063.

Liu, F., 2001. Environmental justice analysis: Theories, methods, and practice. CRC Press, Boca Raton, Fla..

Miller, D., 1992. Distributive Justice: What the People Think. Ethics 102, 555-593.

Miller, D., 1999. Principles of social justice. Harvard Univ. Press, Cambridge Mass.

Mutz, D.C., 2011. Population-based survey experiments. Princeton Univ. Press, Princeton.

Rossi, P.H., 1979. Vignette analysis: uncovering the normative structure of complex judgements, in: Merton, R.K., Coleman, J.S., Rossi, P.H. (Eds.), Qualitative and quantitative social research. Papers in honor of Paul F. Lazarsfeld. Free Press, New York, pp. 176-186.

Sandel, M.J., 2010. Justice: What's the right thing to do? Penguin Books, London.

Sauer, C.G., Auspurg, K., Hinz, T., Liebig, S., 2011. The application of factorial surveys in general population samples: The effects of respondent age and education on response times and response consistency. Survey Research Methods 5, 89-102.

Schlosberg, D., 2007. Defining environmental justice: Theories, movements, and nature. Oxford University Press, Oxford.

Sovacool, B.K., Heffron, R.J., McCauley, D., Goldthau, A., 2016. Energy decisions reframed as justice and ethical concerns. Nat. Energy 1, 16024. 10.1038/nenergy.2016.24.

Walker, B.J.A., Russel, D., Kurz, T., 2016. Community Benefits or Community Bribes?: An Experimental Analysis of Strategies for Managing Community Perceptions of Bribery Surrounding the Siting of Renewable Energy Projects. Environment and Behavior 49, 5983. $10.1177 / 0013916515605562$.

Walker, C., Baxter, J., 2017. "It's easy to throw rocks at a corporation": Wind energy development and distributive justice in Canada. Journal of Environmental Policy \& Planning 19, 754-768. 10.1080/1523908X.2016.1267614.

Wallander, L., 2009. 25 years of factorial surveys in sociology: A review. Social science research 38, 505-520.

Walter, G., Gutscher, H., 2013. Generelle Befürwortung von Windkraftanlagen vor Ort vs. Befürwortung spezifischer Windkraftprojekte: Der Einfluss von Projekt- und Verfahrensparametern. Umweltpsychologie 17, 124-144. 


\section{Zusammenschau und Diskussion der Ergebnisse}

Vor dem Hintergrund der Energiewende und der damit verbundenen Steigerung der Stromerzeugung aus erneuerbaren Energien in Deutschland beschäftigt sich die vorliegende Dissertation mit der Frage, welche Faktoren die Akzeptanz des Ausbaus der erneuerbaren Energien auf lokaler Ebene beeinflussen. Im Fokus stehen dabei die drei wichtigsten erneuerbaren Energieträger Wind-, Solar- und Bioenergie. Auf Grundlage einer quantitativen online-Befragung mit 3400 Teilnehmern, die 2013 deutschlandweit durchgeführt wurde, trägt die Arbeit sowohl aus inhaltlicher als auch aus methodischer Sicht dreierlei zur Forschung in diesem Themenbereich bei.

Inhaltlich wird in Beitrag 1 zunächst auf die Vielfalt der derzeit untersuchten theoretischen Ansätze eingegangen, indem die Erklärungskraft konkurrierender theoretischer Ansätze wie Einstellungen, soziale Normen, bedingte Kooperation, Not-In-My-Backyard-Verhalten (NIMBY) und place attachment (die emotionale Bindung zum umgebenden Raum) für Akzeptanz von und Protest gegen Windkraft-, Solar- und Biogasanlagen untersucht wird. Methodisch gibt dieser Beitrag ein Beispiel, wie der Effekt von Einstellungen unter Verwendung von Dekompositionsmodellen in einen erklärten Teil (endowment effect) und einen unerklärten Teil (discrimination effect und characteristic effect) zerlegt werden kann.

In Beitrag 2 und 3 wird der Raumwirksamkeit von Anlagen zur Stromerzeugung aus erneuerbaren Energien Rechnung getragen und untersucht, welchen Einfluss räumliche Merkmale wie beispielsweise die Distanz vom Wohnort eines Befragten zu bestehenden Anlagen auf die Akzeptanz von erneuerbaren Energien auf lokaler Ebene haben. Der aktuelle Stand der Forschung in diesem Bereich wird in Beitrag 2 im Rahmen eines Review-Artikels präsentiert. Beitrag 3 untersucht die Akzeptanz von Biogasanlagen unter Berücksichtigung der bestehenden Biogasanlagen und des Umfangs des Maisanbaus in der Umgebung der Befragten. Methodisch gibt Beitrag 3 ein Beispiel dafür, wie unter Verwendung von Geographischen Informationssystemen Raumdaten in die Analyse von Umfragedaten integriert werden können. Zuletzt fokussiert Beitrag 4 auf Aspekte der Verteilungs- und Verfahrensgerechtigkeit des Ausbaus der erneuerbaren Energien und geht der Frage nach, wie gerecht bzw. ungerecht unterschiedliche Ausbauszenarien empfunden werden. Dabei kommt ein Faktorielles Survey Experiment zum Einsatz, auf dessen Basis der gewichtete Einfluss unterschiedlicher Merkmale auf die abhängige Variable bestimmt werden kann. Methodisch hervorzuheben ist, dass der 
Beitrag ein direktes Maß für die wahrgenommene Gerechtigkeit einsetzt, anstatt, wie bisherige Studien, den Einfluss von Gerechtigkeitsaspekten auf die Akzeptanz zu untersuchen.

Im Folgenden werden die wichtigsten Ergebnisse dargestellt und diskutiert. Zudem werden Schlussfolgerungen für den weiteren Ausbau der erneuerbaren Energien gezogen, die Herangehensweise kritisch beleuchtet und Verbesserungsmöglichkeiten aufgezeigt.

Aus den Untersuchungen des 1 . Beitrags zeigt sich in Übereinstimmungen mit anderen Studien (Engels et al. 2013; Bertsch et al. 2016), dass Solaranlagen die höchsten Akzeptanz- und niedrigsten Protestwerte aufweisen, gefolgt von Windkraft- und Biogasanlagen. Die endowment effects aus den Dekompositionsmodellen zeigen, dass die Eigenschaften von Windkraft- und Solaranlagen als ähnlich wahrgenommen werden ebenso wie diejenigen von Biogasanlagen und Gaskraftwerken. Zu ähnlichen Ergebnissen kommen Demski et al. (2015), die berichten, dass Bioenergie nicht mit Solar- und Windenergie gleichgesetzt wird, sondern Assoziationen zu fossilen Energieträgern bestehen. Die Sorge um den Klimawandel beeinflusst die Akzeptanz von Windkraft- und Solaranlagen positiv, hat jedoch auf die Akzeptanz von Biogasanlagen keinen Einfluss. Dies zeigt, dass Biogasanlagen nicht mit Klimaschutz in Verbindung gebracht werden. Insgesamt weisen diese Ergebnisse auf eine skeptische Haltung gegenüber Biogasanlagen hin. Die positive Einstellung der Befragten gegenüber Solaranlagen wird durch die Ergebnisse des Faktoriellen Survey Experiments in Beitrag 4 bestätigt. Ausschließlich für Solaranlagen wird es von den Befragten als ungerecht empfunden, wenn es in ihrer Region weniger Solaranlagen gibt als in den meisten anderen Regionen in Deutschland. Ähnlich wie bei Swofford und Slattery (2010) teilt nur ein kleiner Anteil der Befragten in der Stichprobe NIMBY-Überzeugungen, jedoch zeigen diese NIMBY-Überzeugungen über alle Modelle hinweg signifikante Effekte auf Akzeptanz und Protest. Dieses Ergebnis stimmt auch mit der Argumentation von Bell et al. (2013) überein, die von einem kleinen Bevölkerungsanteil mit NIMBY-Überzeugungen ausgehen. Ähnlich wie McAdam und Boudet (2012), die für die USA in einer vergleichenden Studie feststellen, dass insgesamt betrachtet Gegner eher einen geringen Einfluss auf Entscheidungsprozesse von environmentally risky energy projects nehmen, berichten auch Marg et al. (2013) mit Blick auf den Ausbau der erneuerbaren Energien in Deutschland, dass Protestgruppen und ihre Anhänger in Deutschland weniger zahlreich sind als angenommen. Sie argumentieren, dass die Überschätzung des Protestumfangs aus der medialen Aufmerksamkeit und der politischen Brisanz dieses Themas resultiert. Auch für die Wissenschaft besteht die Gefahr, Proteste zu stark in den Blick zu nehmen und somit eine verzerrte Wahrnehmung von abgelehnten und befürworteten Ausbauprojekten zu fördern. 
Wolsink (2007) argumentiert, dass Ablehnung von erneuerbaren Energien auf lokaler Ebene häufig aus fehlender Verfahrensgerechtigkeit resultiert, anstelle in NIMBY-Überzeugungen begründet zu sein. So führen Entscheidungen, die über die Köpfe der Betroffenen hinweg getroffen werden, zu ablehnendem Verhalten. Während der 4. Beitrag der Dissertation zeigt, dass die Möglichkeit zur Mitsprache einen signifikant positiven Einfluss auf die wahrgenommene Gerechtigkeit des Ausbaus der erneuerbaren Energien hat - ebenso wie Aspekte der Verteilungsgerechtigkeit - konnten in Beitrag 1 Aspekte der Verfahrens- und Verteilungsgerechtigkeit als weitere konkurrierende theoretische Ansätze nicht berücksichtigt werden. Somit bleibt offen, ob diese den Effekt von NIMBY verdrängen würden.

Place attachment hat im 1. Beitrag einen signifikant positiven Einfluss auf die Protestbereitschaft, im Gegensatz zu Read et al. (2013), die keinen signifikanten Effekt finden. Es findet sich jedoch kein deutlicher Einfluss von place attachment auf die lokale Akzeptanz von erneuerbaren Energien (nur für Solaranlagen zeigt place attachment einen signifikant negativen Effekt), im Gegensatz zu Vorkinn und Riese (2001) und zu Devine-Wright (2013), die einen negativen und zu Devine-Wright (2011), der einen positiven Effekt berichtet. Auch im 3. Beitrag kann kein konsistenter Effekt von place attachment auf die lokale Akzeptanz von Biogasanlagen festgestellt werden. Hier hat place attchment nur einen signifikant positiven Einfluss auf die Akzeptanz von Biogasanlagen, wenn die Kovariate „Einstellung zum Maisanbau“ im Modell enthalten ist. Im separaten Modell, das neben der Kovariaten place attachment nur die soziodemographischen Variablen enthält, ist der Koeffizient nicht signifikant. Zwar sind place attachment und „Einstellung zum Maisanbau“ negativ korreliert, jedoch hat ein Interaktionseffekt beider Variablen keinen signifikanten Einfluss auf die Akzeptanz. Deswegen wird der Effekt von place attachment in Beitrag 3 nicht weiter berücksichtigt. Die Relevanz von place attachment mit Blick auf die Protestbereitschaft unterstreicht, dass die Möglichkeit zur Teilhabe und Mitgestaltung im Planungsprozess einer Anlage im Sinne der Verfahrensgerechtigkeit bedeutend ist, um Anwohnern Gehör zu verschaffen und ihre Sorgen zu berücksichtigen (Gross 2007; Wolsink 2007).

Bedingte Kooperation (also die Bedingung, dass für den eigenen Beitrag auch andere zum Klimaschutz beitragen) spielt mit Blick auf die Protestbereitschaft gegen Wind- und Solaranlagen eine Rolle. Damit zeigt die Untersuchung ähnliche Ergebnisse wie frühere Studien aus unterschiedlichen Bereichen (Ek und Söderholm 2007 für den Kontext Windenergie, Liebe et al. 2011 für den Kontext Biodiversität). Es zeigt sich, dass bei den beiden Energieträgern, die von den Befragten mit Klimaschutz verbunden werden, bedingte 
Kooperation positiv mit der Protestbereitschaft verbunden ist. Dieser Zusammenhang kann auch als Hinweis auf die Relevanz von Verteilungsgerechtigkeit interpretiert werden. Im Gegensatz zu Read et al. (2013) konnte ein relevanter Einfluss sozialer Normen auf Akzeptanz oder Protest nicht festgestellt werden.

Insgesamt stehen die Ergebnisse des Theorievergleichs aus dem 1. Beitrag somit zum Teil im Einklang und zum Teil im Gegensatz zur bisherigen Literatur. Zukünftige Studien, die in unterschiedlichen Kontexten den Einfluss konkurrierender theoretischer Ansätze auf Akzeptanz, Protest oder Bereitschaft zur Partizipation untersuchen, sind deswegen wünschenswert. Dabei sollten unbedingt weitere theoretische Konzepte wie beispielsweise Gerechtigkeitsaspekte oder Vertrauen berücksichtigt werden. Erst eine größere Anzahl an Studien könnte zeigen, welche theoretischen Ansätze mehr und welche weniger relevant sind, um ein bestimmtes Verhalten zu erklären. Zudem dienen solche Anwendungen der kritischen Bewertung der theoretischen Ansätze selbst: es kann überprüft werden, welche theoretischen Ansätze zur Erklärung welcher Phänomene einen Erklärungsbeitrag leisten können.

Die Anwendung der Dekompositionsmodelle zeigt, dass die drei betrachteten erneuerbaren Energieträger nicht nur entsprechend ihrer Eigenschaften unterschiedlich bewertet werden, sondern auch, dass bei der Bewertung beispielsweise mit Blick auf die Landschaftsauswirkung der einzelnen Anlagen unterschiedliche Bewertungsmaßstäbe angesetzt werden. Die Kenntnis dieser Unterschiede ermöglicht es, bei der Planung von Anlagen auf die Sorgen und Belange von Anwohnern besser einzugehen und so Projekte erfolgreicher umzusetzen. Aus methodischer Sicht zeigt Beitrag 1, wie bereits die Studie von Ansolabehere und Konisky (2009), dass die Anwendung von Dekompositionsmodellen auch in der Einstellungsforschung wertvolle Erkenntnisse liefern kann und ermutigt so zu einer Anwendung auch außerhalb des Kontextes Energie.

Zwei Beiträge dieser Dissertation beschäftigen sich mit der Berücksichtigung des räumlichen Kontextes durch die Integration von Rauminformation in der Datenanalyse. Der Literaturüberblick dazu zeigt, dass die Anzahl bisheriger Studien mit $21 \mathrm{sehr}$ begrenzt ist und dass sie sich in der Art und Weise, wie der räumliche Kontext berücksichtigt wird, sehr unterscheiden. Zum einen kann die Datenquelle unterschieden werden: viele Studien basieren auf subjektiv berichteten räumlichen Informationen, die im Rahmen einer Befragung erhoben wurden. Nur neun Studien verwenden objektive Daten. Zum zweiten variiert die Messung und damit die Genauigkeit der Daten sehr. Zu bemerken ist außerdem, dass ein Teil der betrachteten Studien räumliche Aspekte von geplanten Anlagen integriert, ein anderer Teil jedoch räumliche 
Daten zu bestehenden Anlagen heranzieht. Vor dem Hintergrund des u-förmigen Verlaufs des Akzeptanzniveaus in der Zeit von der Planung bis nach der Fertigstellung der Anlage (Wolsink 2007; Devine-Wright 2005), ist in diesen unterschiedlichen Settings jedoch mit starken Unterschieden bei der Bewertung der Anlagen zu rechnen. Somit dient der Literaturüberblick insbesondere dazu, die Vielfalt der methodischen Herangehensweisen darzustellen. Über den Einfluss der räumlichen Nähe und anderer Faktoren der räumlichen Betroffenheit auf die Akzeptanz kann auf Basis des Literaturüberblicks nur eine sehr begrenzte Aussage gemacht werden. In der Tendenz ist der Effekt eher negativ. Der Literaturüberblick verdeutlicht, dass bisher nur wenige Studien, die den räumlichen Kontext in ihrer Untersuchung berücksichtigen, auf Geographische Informationssysteme und die damit verbundenen Möglichkeiten, die räumliche Umgebung von Befragten abzubilden (s. dazu Meyer und Bruderer Enzler 2013), zurückgreifen.

Beitrag 3 knüpft an diese methodische Lücke an und bietet mit Blick auf die Akzeptanz von Biogasanlagen ein Beispiel, wie räumliche Informationen in die Analyse von Umfragedaten integriert werden können. Besonders ist dabei, dass der Betrieb von Biogasanlagen zwei räumliche Komponenten umfasst, einerseits den Standort der Anlage selbst, andererseits den notwendigen Substratanbau, in der Regel Mais. Die Berücksichtigung räumlicher Daten als erklärende Variablen zeigt interessante Ergebnisse: der Umfang des Maisanbaus in der Umgebung der Befragten hat einen signifikant negativen Effekt auf die lokale Akzeptanz von Biogasanlagen, auch wenn die Erklärungskraft gering ist. Die Nähe von Biogasanlagen zum Wohnort der Befragten nimmt dagegen positiven Einfluss auf die Akzeptanz, dieser Effekt ist jedoch im Gesamtmodel nicht signifikant. Der Hinweis auf einen positiven Zusammenhang könnte mit Gewöhnung und mehr Erfahrung mit oder Wissen (Brody et al. 2004; DevineWright 2005) über die Biogastechnologie zusammenhängen. Kognitive Dissonanz (Festinger 1957) ist eher auszuschließen, da sich diese auch mit Blick auf den Umfang des Maisanbaus zeigen müsste.

Der negative Effekt des Umfangs des Maianbaus entspricht der kritischen Haltung gegenüber dem Maisanbau, die sich auch aus den Einstellungsmessungen zum Maisanbau ergibt. Biogasanlagen haben sich zu einem zweiten Standbein der Landwirtschaft entwickelt und dienen im Rahmen des Ausbaus der erneuerbaren Energien dazu, die Schwankungen in der Stromerzeugung aus Wind- und Solarenergie auszugleichen. Um die Akzeptanz zu erhöhen, sollte deswegen auf eine stärkere Diversifizierung der eingesetzten Substrate geachtet werden. 
Der Einsatz des Faktoriellen Survey Experiments im 4. Beitrag zeigt, dass sowohl Aspekte der Verfahrens- als auch Aspekte der Verteilungsgerechtigkeit signifikant darauf Einfluss haben, wie gerecht oder ungerecht ein Ausbauszenario empfunden wird. Der Gestaltung der entsprechenden Attribute im Faktoriellen Survey Experiment liegt das Gleichheitsprinzip zugrunde: entsprechend der Formulierung im Faktoriellen Survey Experiment heißt das mit Blick auf die Verteilungsgerechtigkeit, dass es in der Region des Befragten genauso viele Anlagen gibt, wie in den meisten anderen Regionen in Deutschland. Mit Blick auf die Verfahrensgerechtigkeit heißt das, dass die betroffenen Anwohner bei jeder Entscheidung im Planungsprozesses die Möglichkeit zur Mitbestimmung haben. Es zeigt sich jedoch, dass die wahrgenommene Gerechtigkeit nicht auf einer Gleichverteilung beruht. Deswegen wäre es im nächsten Schritt sinnvoll zu untersuchen, welche Verteilung (vgl. Beatley 1984) für die einzelnen Energieträger als gerecht empfunden wird und somit, welche Gerechtigkeitsprinzipien mit Blick auf die Verteilung und die Gestaltung der Mitbestimmung von Relevanz sind.

Das in Beitrag 4 vorgestellte Faktorielle Survey Experiment ist eine erste Anwendung der Methode zur direkten Messung der wahrgenommenen Gerechtigkeit des Ausbaus der erneuerbaren Energien. Die verwendete Vignette enthält vier unterschiedliche Merkmale mit jeweils drei Ausprägungen. Jedoch gibt es weitere gerechtigkeitsrelevante Merkmale (vgl. Liebe et al. 2017): wer profitiert von der Anlage finanziell? Fallen Steuereinnahmen für die Gemeinde an? Wer konsumiert den erzeugten Strom? Sie könnten in einer Folgestudie berücksichtigt werden. Interessant wäre zudem, Untersuchungen $\mathrm{zu}$ Aspekten der Verteilungsgerechtigkeit mit räumlichen Informationen $\mathrm{zu}$ bestehenden Anlagen $\mathrm{zu}$ verknüpfen, um so zu bestimmen, inwiefern die Zahl der Anlagen in der Umgebung eines Befragten seine Vorstellungen über eine gerechte räumliche Verteilung der Anlagen beeinflusst.

\section{Kritische Einordnung der Herangehensweise und Verbesserungsvorschläge}

Die Untersuchung basiert auf einer online-Befragung mit 3400 Teilnehmern, die innerhalb eines telefonisch rekrutierten Access-Panels durchgeführt wurde. Es handelt sich damit um eine große Stichprobe, die aber insbesondere mit Blick auf das hohe durchschnittliche Bildungsniveau der Befragten nicht repräsentativ für die deutsche Bevölkerung ist. Jedoch ist es nicht Ziel der Untersuchung, Mittelwerte und Anteile zur Akzeptanz erneuerbarer Energien zu präsentieren, sondern Aussagen über mögliche Zusammenhänge zu treffen und so Ursachen 
für Akzeptanz und Protest zu bestimmen. Da diese Schätzung von Zusammenhängen im Gegensatz zu Mittelwerten und Randverteilungen recht robust gegenüber systematischen Stichprobenfehlern ist (Diekmann 2011) und die Stichprobe trotz des hohen Bildungsniveaus der Befragten ausreichend Varianz in den soziodemographischen Merkmalen zeigt, kann der Einfluss von Einstellungen und anderen theoretischen Ansätzen auf die lokale Akzeptanz erneuerbarer Energien anhand der Daten untersucht werden. Mit höherer Bildung ist meist auch ein höheres Umweltbewusstsein verbunden (z.B., van Liere und Dunlap 1980). Da soziodemographische Merkmale als Kontrollvariablen in die Modelle einbezogen sind, sollte auch dies der Überprüfung von Zusammenhängen anhand der Daten nicht entgegenstehen.

Eine Alternative zu einer online-Erhebung, die eine Ursache für das hohe Bildungsniveau sein kann (Diekmann 2011), wäre eine postalische Befragung. Hier kann, bei entsprechenden Maßnahmen zur Erhöhung der Rücklaufquote (s. Dillman et al. 2014) eine Zufallsstichprobe aus der Gesamtbevölkerung eher realisiert werden, da die Grundgesamtheit der Gesamtbevölkerung und nicht nur den Internetnutzern entspricht (Dillman et al. 2014). Ein Vorteil einer solchen postalischen Befragung wäre mit Blick auf die Integration räumlicher Daten die Verfügbarkeit exakter Angaben zum jeweiligen Wohnort. Auf Basis solcher Daten könnte sich die Umgebung der Befragten noch genauer abbilden lassen, bis hin zu einer Sichtfeldanalyse, mit der man beispielsweise bestimmen könnte, ob vom Wohnhaus des Befragten Windräder zu sehen sind oder nicht. Wichtig ist, dass bei der Verwendung exakter Informationen zum Wohnort der Datenschutz der Befragten gewährleistet ist (s. dazu Müller et al. 2017).

Die im 3. Beitrag verwendeten Daten zum Maisanbau sind der Landwirtschaftszählung 2010 entnommen. Diese Daten werden nur etwa alle zehn Jahre erhoben und liegen nur auf Gemeindeebene vor. Um den räumlichen Kontext der Befragten besser abzubilden, wäre es wünschenswert gewesen, zum Erhebungsjahr 2013 passende Daten zum Maisanbau zu verwenden, die vorliegenden Daten sind jedoch drei Jahre älter. Da jedoch der Maisanteil an der gesamten landwirtschaftlichen Nutzfläche in Deutschland in 2010 und 2013 recht stabil ist, sollte auch die Differenz auf Gemeindeebene sehr begrenzt sein. Von Vorteil wären jedoch weniger stark aggregierte Daten zum Maisanbau (beispielsweise auf Feldblock-Ebene), wie sie in den InVeKoS-Daten (Integriertes Verwaltungs- und Kontrollsystem) vorliegen (Laggner et al. 2014). Deren Nutzung war jedoch im Rahmen der vorliegenden Dissertation aus Datenschutzgründen nicht möglich. 
Die Daten der vorliegenden Untersuchung stammen aus einer deutschlandweiten Befragung. Entsprechend erfolgt eine hypothetische Evaluierung eines Anlagenbaus. Es wird kein tatsächliches Verhalten gemessen, sondern lediglich eine hypothetische Aussage zu einem Verhalten. Jedoch schlagen sich nicht alle Verhaltensintentionen in tatsächlichem Verhalten nieder, so dass ein hypothetical bias vorliegen kann. Im Rahmen von Fallstudien, die regional begrenzt sind und so beispielsweise in einem bestimmten Umkreis von geplanten Anlagen durchgeführt werden könnten, wäre der Inhalt der Fragen für die Befragten deutlich konkreter. Gegebenenfalls könnte auch tatsächliches Verhalten gemessen oder beobachtet werden. Auch könnten detailliertere räumliche Informationen erhoben werden. Jedoch ist ein enger räumlicher Fokus mit Blick auf eine kleine Region auch deutlich nachteilig, so dass je nach Untersuchungskontext abgewogen werden muss, ob eine Fallstudie oder eine Befragung auf nationaler Ebene die bessere Wahl ist.

\section{Literatur}

Ansolabehere, Stephen; Konisky, David M. (2009): Public Attitudes Toward Construction of New Power Plants. In: Public Opinion Quarterly 73 (3), S. 566-577. DOI: 10.1093/poq/nfp041.

Beatley, Timothy (1984): Applying Moral Principles to Growth Management. In: Journal of the American Planning Association 50 (4), S. 459-469. DOI: 10.1080/01944368408976777.

Bell, Derek; Gray, Tim; Haggett, Claire; Swaffield, Joanne (2013): Re-visiting the 'social gap'. Public opinion and relations of power in the local politics of wind energy. In: Environmental Politics 22 (1), S. 115-135. DOI: 10.1080/09644016.2013.755793.

Bertsch, Valentin; Hall, Margeret; Weinhardt, Christof; Fichtner, Wolf (2016): Public acceptance and preferences related to renewable energy and grid expansion policy. Empirical insights for Germany. In: Energy 114, S. 465-477. DOI: 10.1016/j.energy.2016.08.022.

Brody, Samuel D.; Highfield, Wes; Alston, Letitia (2004): Does Location Matter? In: Environment and Behavior 36 (2), S. 229-250. DOI: 10.1177/0013916503256900.

Demski, Christina; Butler, Catherine; Parkhill, Karen A.; Spence, Alexa; Pidgeon, Nick F. (2015): Public values for energy system change. In: Global Environmental Change 34, S. 59-69. DOI: 10.1016/j.gloenvcha.2015.06.014.

Devine-Wright, Patrick (2005): Beyond NIMBYism. Towards an integrated framework for understanding public perceptions of wind energy. In: Wind Energy 8 (2), S. 125-139. DOI: 10.1002/we. 124 .

Devine-Wright, Patrick (2011): Place attachment and public acceptance of renewable energy. A tidal energy case study. In: Journal of Environmental Psychology 31 (4), S. 336-343. DOI: 10.1016/j.jenvp.2011.07.001. 
Devine-Wright, Patrick (2013): Explaining “NIMBY" Objections to a Power Line. The Role of Personal, Place Attachment and Project-Related Factors. In: Environment and Behavior 45 (6), S. 761-781. DOI: 10.1177/0013916512440435.

Diekmann, Andreas (2011): Empirische Sozialforschung. Grundlagen, Methoden, Anwendungen. Orig.-Ausg., vollst. überarb. und erw. Neuausg. 2007, 5. Aufl., [22. Aufl. der Gesamtausg.]. Reinbek bei Hamburg: Rowohlt-Taschenbuch-Verlag (Rororo Rowohlts Enzyklopädie, 55678).

Dillman, Don A.; Smyth, Jolene D.; Christian, Leah Melani (2014): Internet, phone, mail, and mixed-mode surveys. The tailored design method. $4^{\text {th }}$ edition. Hoboken, NJ: Wiley.

Ek, Kristina; Söderholm, Patrik (2007): Public Support for Renewable Electricity: The Importance of Policy Framing. In: Carolyn C. Pertsova (Hg.): Ecological economics research trends. New York, NY: Nova Science Publ, S. 83-104.

Engels, Anita; Hüther, Otto; Schäfer, Mike; Held, Hermann (2013): Public climate-change skepticism, energy preferences and political participation. In: Global Environmental Change 23 (5), S. 1018-1027. DOI: 10.1016/j.gloenvcha.2013.05.008.

Festinger, Leon (1957): A theory of cognitive dissonance. Evanston: Row, Peterson.

Gross, Catherine (2007): Community perspectives of wind energy in Australia. The application of a justice and community fairness framework to increase social acceptance. In: Energy Policy 35 (5), S. 2727-2736. DOI: 10.1016/j.enpol.2006.12.013.

Laggner, Birgit; Orthen, Natascha; Osterburg, Bernhard; Röder, Norbert (2014): Ist die zunehmende Biogasproduktion die alleinige Ursache für den Grünlandschwund in Deutschland? - eine Analyse von georeferenzierten Daten zur Landnutzung. In: Raumforschung und Raumordnung 72 (3), S. 195-209. DOI: 10.1007/s13147-014-0278-7.

Liebe, Ulf; Bartczak, Anna; Meyerhoff, Jürgen (2017): A turbine is not only a turbine. The role of social context and fairness characteristics for the local acceptance of wind power. In: Energy Policy 107, S. 300-308. DOI: 10.1016/j.enpol.2017.04.043.

Liebe, Ulf; Preisendörfer, Peter; Meyerhoff, Jürgen (2011): To Pay or Not to Pay. Competing Theories to Explain Individuals' Willingness to Pay for Public Environmental Goods. In: Environment and Behavior 43 (1), S. 106-130. DOI: 10.1177/0013916509346229.

Marg, Stine; Hermann, Christoph; Hambauer, Verena; Becké, Ana Belle (2013): „Wenn man was für die Natur machen will, stellt man da keine Masten hin“. Bürgerproteste gegen Bauprojekte im Zuge der Energiewende. In: Stine Marg, Lars Geiges, Felix Butzlaff und Franz Walter (Hg.): Die neue Macht der Bürger. Was motiviert die Protestbewegungen?; BP-Gesellschaftsstudie. Reinbek bei Hamburg: Rowohlt, S. 94-138.

McAdam, Doug; Boudet, Hilary (2012): Putting social movements in their place. Explaining opposition to energy projects in the United States, 2000-2005. New York: Cambridge University Press.

Meyer, Reto; Bruderer Enzler, Heidi (2013): Geographische Informationssysteme (GIS) und ihre Anwendung in den Sozialwissenschaften am Beispiel des Schweizer Umweltsurveys. In: Methoden, Daten, Analysen 7 (3), S. 317-346. DOI: 10.12758/mda.2013.016.

Müller, Stefan; Schweers, Stefan; Siegers, Pascal; GESIS - Leibniz-Institut für Sozialwissenschaften (Ed.) (2017): Geocoding and spatial linking of survey data: an 
introduction for social scientists. Köln (GESIS Papers, 2017/15). Online verfügbar unter http://nbn-resolving.de/urn:nbn:de:0168-ssoar-52316-9, zuletzt geprüft am 03.03.2019.

Read, Darryl L.; Brown, Rhonda F.; Thorsteinsson, Einar B.; Morgan, Methuen; Price, Ian (2013): The theory of planned behaviour as a model for predicting public opposition to wind farm developments. In: Journal of Environmental Psychology 36, S. 70-76. DOI: 10.1016/j.jenvp.2013.07.001.

Swofford, Jeffrey; Slattery, Michael (2010): Public attitudes of wind energy in Texas. Local communities in close proximity to wind farms and their effect on decision-making. In: Energy Policy 38 (5), S. 2508-2519. DOI: 10.1016/j.enpol.2009.12.046.

van Liere, Kent D.; Dunlap, Riley E. (1980): The Social Bases of Environmental Concern. A Review of Hypotheses, Explanations and Empirical Evidence. In: Public Opinion Quarterly 44 (2), S. 181. DOI: 10.1086/268583.

Vorkinn, M.; Riese, H. (2001): Environmental Concern in a Local Context. The Significance of Place Attachment. In: Environment and Behavior 33 (2), S. 249-263. DOI: 10.1177/00139160121972972.

Wolsink, Maarten (2007): Planning of renewables schemes. Deliberative and fair decisionmaking on landscape issues instead of reproachful accusations of non-cooperation. In: Energy Policy 35 (5), S. 2692-2704. DOI: 10.1016/j.enpol.2006.12.002. 


\section{Zusammenfassung}

Vor dem Hintergrund der Energiewende und der damit verbundenen Steigerung der Stromerzeugung aus erneuerbaren Energien in Deutschland beschäftigt sich die vorliegende Dissertation mit der Frage, welche Faktoren die Akzeptanz des Ausbaus der erneuerbaren Energien auf lokaler Ebene beeinflussen. Im Fokus stehen dabei die drei wichtigsten erneuerbaren Energieträger Wind-, Solar- und Bioenergie. Auf Grundlage einer quantitativen online-Befragung mit 3400 Teilnehmern, die 2013 deutschlandweit durchgeführt wurde, trägt die Arbeit sowohl aus inhaltlicher als auch aus methodischer Sicht dreierlei zur Forschung in diesem Themenbereich bei.

Inhaltlich wird in Beitrag 1 zunächst auf die Vielfalt der derzeit untersuchten theoretischen Ansätze eingegangen, indem die Erklärungskraft konkurrierender theoretischer Ansätze wie Einstellungen, soziale Normen, bedingte Kooperation, Not-In-My-Backyard-Verhalten (NIMBY) und place attachment, d.h. die emotionale Bindung zum umgebenden Raum, für Akzeptanz von und Protest gegen Windkraft-, Solar- und Biogasanlagen untersucht wird. Methodisch gibt dieser Beitrag ein Beispiel, wie der Effekt von Einstellungen unter Verwendung von Dekompositionsmodellen in einen erklärten Teil (endowment effect) und einen unerklärten Teil (discrimination effect und characteristic effect) zerlegt werden kann. Im Ergebnis weisen Solaranlagen die höchsten Akzeptanz- und niedrigsten Protestwerte auf, gefolgt von Windkraft- und Biogasanlagen. Die stärkste Erklärungskraft hinsichtlich Akzeptanz und Protest unter den konkurrierenden Ansätzen haben Einstellungen und NIMBYÜberzeugungen. Place Attachment und bedingte Kooperation leisten darüber hinaus einen Beitrag für die Erklärung von Protest. Die Anwendung der Dekompositionsmodelle erklärt die unterschiedliche Bewertung der einzelnen Energieträger mit endowment effects, jedoch zeigen sich teilweise auch discrimination und characteristic effects.

In Beitrag 2 und 3 wird der Raumwirksamkeit von Anlagen zur Stromerzeugung aus erneuerbaren Energien Rechnung getragen und untersucht, welchen Einfluss räumliche Merkmale wie beispielsweise die Distanz zwischen dem Wohnort eines Befragten und bestehenden Anlagen auf die Akzeptanz von erneuerbaren Energien auf lokaler Ebene haben. Der aktuelle Stand der Forschung in diesem Bereich wird in Beitrag 2 im Rahmen eines Review-Artikels präsentiert. Beitrag 3 untersucht die Akzeptanz von Biogasanlagen unter Berücksichtigung von bereits bestehenden Biogasanlagen und des Umfangs des Maisanbaus in der Umgebung der Befragten. Methodisch gibt Beitrag 3 ein Beispiel dafür, wie unter 
Verwendung von Geographischen Informationssystemen Raumdaten in die Analyse von Umfragedaten integriert werden können. Im Ergebnis zeigt sich, dass vor allem der Umfang des Maisanbaus in der Umgebung der Befragten einen negativen Effekt auf die Akzeptanz einer Biogasanlage hat, während die Nähe zu bestehenden Biogasanlagen die Akzeptanz positiv beeinflusst.

Zuletzt fokussiert der 4. Beitrag der Dissertation auf Aspekte der Verteilungs- und Verfahrensgerechtigkeit des Ausbaus der erneuerbaren Energien und geht der Frage nach, wie gerecht bzw. ungerecht unterschiedliche Ausbauszenarien empfunden werden. Dabei kommt ein Faktorielles Survey Experiment zum Einsatz: den Befragten wird darin eine Beschreibung eines Ausbauszenarios vorgelegt, die in mehreren Gerechtigkeits-relevanten Merkmalen experimentell variiert wird. Diese Beschreibung wird von den Befragten hinsichtlich der empfundenen Gerechtigkeit bewertet. Aufgrund des experimentellen Setups der Methode kann dann der relative Einfluss der einzelnen Merkmale auf die Bewertung bestimmt werden. Die Analysen zeigen, dass sowohl die Verfahrensgerechtigkeit als auch die Verteilungsgerechtigkeit für die Bewertung der wahrgenommenen Gerechtigkeit relevant sind. Methodisch hervorzuheben ist, dass der Beitrag ein direktes Maß für die wahrgenommene Gerechtigkeit einsetzt anstatt, wie bisherige Studien, den Einfluss von Gerechtigkeitsaspekten auf die Akzeptanz zu untersuchen.

Die Dissertation endet mit einer Zusammenschau und Diskussion der Ergebnisse. Hier wird die Herangehensweise kritisch beleuchtet, Verbesserungsmöglichkeiten aufgezeigt und Schlussfolgerungen mit Blick auf den weiteren Ausbau der erneuerbaren Energien gezogen. 


\section{Erklärung über den geleisteten Eigenanteil}

Der erste Beitrag dieser Dissertation „,Decomposing public support for energy policy: What drives acceptance of and intentions to protest against renewable energy expansion in Germany?" entstand in Zusammenarbeit von Ulf Liebe und mir. Mein Anteil an diesem Artikel setzt sich wie folgt zusammen:

- Konzeption und Durchführung der Fokusgruppen (Vorstudie), Ausarbeitung des Fragebogens, Koordination der Datenerhebung, Datenbereinigung und Datenauswertung (letzteres in enger Rücksprache mit Ulf Liebe).

- Anteiliges Verfassen der Kapitel 2 (Theoretical Background), 3 (Data and Variables) und 4 (Results)

- Überarbeiten des Artikels in enger Zusammenarbeit mit Ulf Liebe.

Der vierte Beitrag dieser Dissertation „Factorial survey instruments and direct measurement of fairness perceptions in energy justice research " entstand in Zusammenarbeit von Ulf Liebe und mir. Mein Anteil an diesem Artikel setzt sich wie folgt zusammen:

- Gemeinsame Idee von Ulf Liebe und mir

- Konzeption und Durchführung der Fokusgruppen (Vorstudie), Ausarbeitung der Vignette, Koordination der Datenerhebung, Datenbereinigung

- Zuarbeit bei dem Verfassen des Textes 


\section{Publikationsliste}

\section{Peer-reviewed}

Liebe, U.; Dobers, G. (2019): Decomposing Public Support for Energy Policy: What Drives Acceptance of and Intentions to Protest against Renewable Energy Expansion in Germany? Energy Research \& Social Science 47, 247-260.

Dobers, G.; Ihle, R.; Kachel, Y., Liebe, U. (2018): Economic integration in the Middle East: Israeli-Palestinian fresh food trade. Israel Affairs, 42(1), S. 1-21.

Jahnke, B.; Liebe, U.; Dobers, G. (2015). Energiewende in Deutschland - Not-In-MyBackyard oder eine Frage der Gerechtigkeit? Zeitschrift für Umweltpolitik und Umweltrecht, 2015(4), S. 367-384.

\section{Vorträge}

Liebe, U.; Merkle, G. (2014): Explaining public attitudes, protests and acceptance towards renewable energy sites. 2nd Energy \& Society Conference, Institute of Sociology, Jagiellonian University, Krakow.

Merkle, G. (2014): Erklärungsbeitrag subjektiver Einstellungen und objektiver Rauminformationen für die Akzeptanz von Biogasanlagen. 24 Jahrestagung der Österreichischen Gesellschaft für Agrarökonomie, Universität für Bodenkultur, Wien.

Meyerhoff, J.; Merkle, G.; Oehlmann, M. (2014): Effects of perceived consequentiality and trust in institutions on stated willingness to pay in discrete choice experiments. World Congress of Environmental and Resource Economists, Istanbul.

Merkle, G.; Ihle, R.; Liebe, U. (2013): "Economic Cooperation in Political Conflict: Problem Perception and Social Embeddedness in Israeli-Palestinian Food Trade." International Conference .Cooperation or Conflict? Economics of Natural Resources and Food, Universität Wageningen.

\section{Poster}

Merkle, G.; Ihle, R.; Liebe, U. (2013): Economic Cooperation Despite of Political Conflict: The Role of Social Embeddedness in the Relationships Between Israeli and Palestinian Food Traders. 53. Jahrestagung der Gesellschaft für Wirtschafts- und Sozialwissenschaften des Landbaus, Humboldt-Universität Berlin.

\section{Sonstige Beiträge}

Dobers, G.; Oehlmann, M.; Liebe, U.; Meyerhoff, J. (2015): Einstellungen und Präferenzen zum Ausbau Erneuerbarer Energien. Ökologisches Wirtschaften 30(1), S. 16-17. 


\section{Eidesstattliche Erklärungen}

1) Hiermit erkläre ich eidesstattlich, dass:

1. diese Arbeit weder in gleicher noch in ähnlicher Form bereits anderen Prüfungsbehörden vorgelegen hat.

2. ich mich an keiner anderen Hochschule um einen Doktorgrad beworben habe.

Göttingen, den

Unterschrift:

2) Hiermit erkläre ich eidesstattlich, dass diese Dissertation selbständig und ohne unerlaubte Hilfe angefertigt wurde.

Göttingen, den

Unterschrift: 